Reconnaissance of Water Quality of

Lake Henry and Lake Meredith Reservoir,

Crowley County, Southeastern Colorado,

April-October 1987

by Joseph R. Sullivan, Jr.

U.S. GEOLOGICAL SURVEY

Water-Resources Investigations Report 91-4102

Prepared in cooperation with the

SOUTHEASTERN COLORADO WATER CONSERVANCY DISTRICT 


\section{U.S. DEPARTMENT OF THE INTERIOR \\ BRUCE BABBITT, Secretary}

U.S. GEOLOGICAL SURVEY

Robert M. Hirsch, Acting Director

The use of trade, product, industry, or firm names is for descriptive purposes only and does not imply endorsement by the U.S. Government.

For additional information write to:

Copies of this report can be purchased from:

District Chief

U.S. Geological Survey

Box 25046, MS 415

Denver Federal Center

Denver, CO 80225
U.S. Geological Survey

Earth Science Information Center

Open-File Reports Section

Box 25286, MS 517

Denver Federal Center

Denver, CO 80225 


\section{CONTENTS}

Abstract …

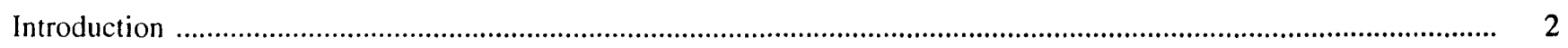

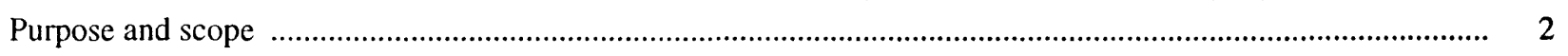

Description of Lake Henry and Lake Meredith ....................................................................................... 2

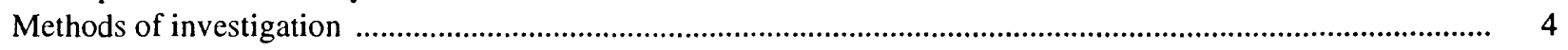

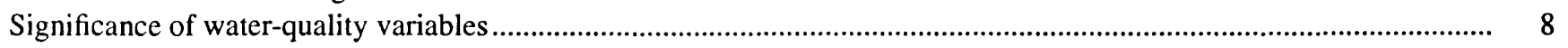

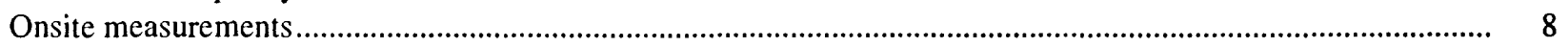

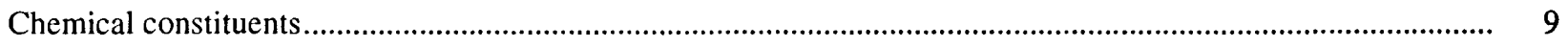

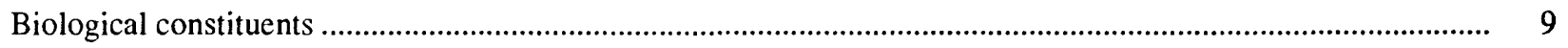

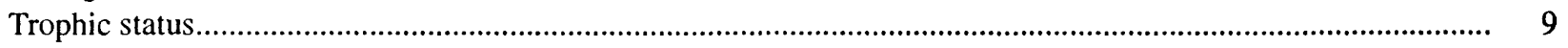

Water-quality characteristics of Lake Henry and comparison to water-quality standards.............................................. 10

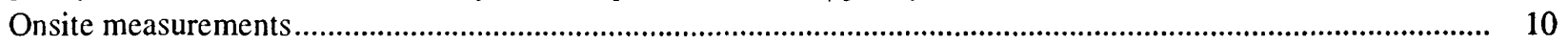

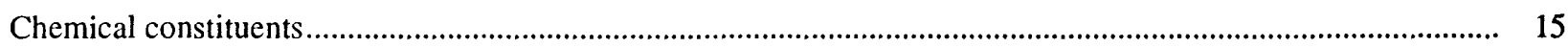

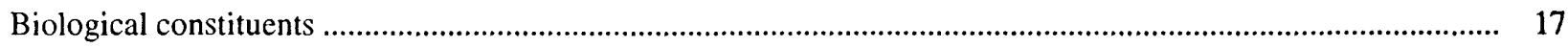

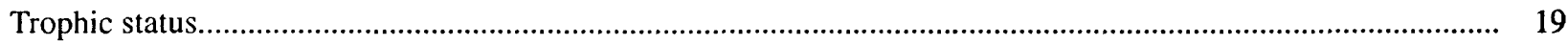

Water-quality characteristics of Lake Meredith and comparison to water-quality standards ........................................ 20

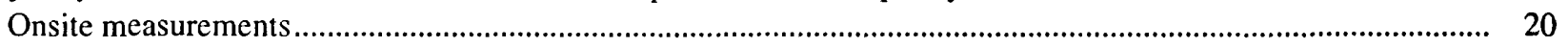

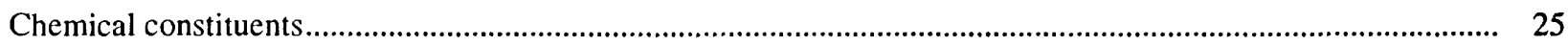

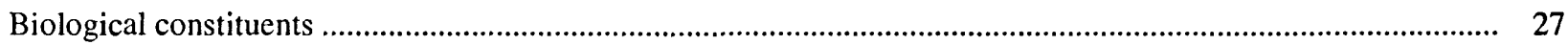

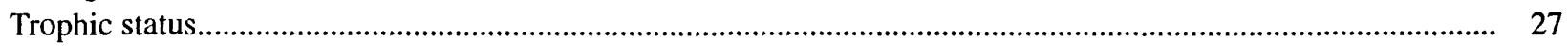

Comparison of selected water-quality characteristics between Lake Henry and Lake Meredith ..................................... 29

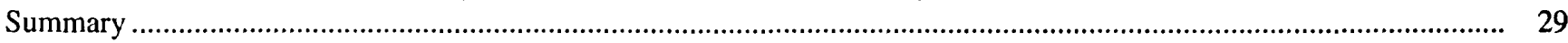

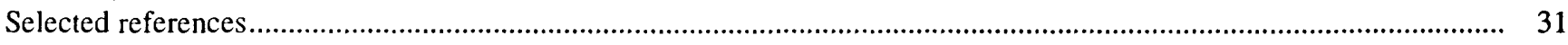

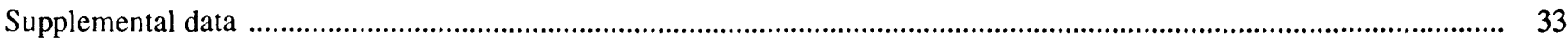

\section{FIGURES}

1-3. Maps showing:

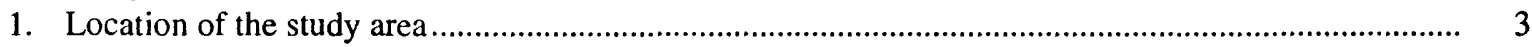

2. Bathymetry and sampling sites at Lake Henry ................................................................................ 5

3. Bathymetry and sampling sites at Lake Meredith................................................................................. 6

4-11. Graphs showing:

4. Profiles of water temperature at depth for sites HEW2, HNW, and HSE at Lake Henry ..................... 11

5. Profiles of dissolved oxygen and $\mathrm{pH}$ at depth for sites HEW2, HNW, and HSE at Lake Henry........... 12

6. Profiles of specific conductance at depth for sites HEW2, HNW, and HSE at Lake Henry.................. 13

7. Densities and taxonomic composition of major phytoplankton groups collected from site HEW2 at Lake Henry on May 1, June 29, August 19, and October 6, 1987............................. 18

8. Profiles of water temperature at depth for sites M2B, M1B, and M4B at Lake Meredith................... 21

9. Profiles of dissolved oxygen and $\mathrm{pH}$ at depth for sites M2B, M1B, and M4B at Lake Meredith .......... 22

10. Profiles of specific conductance at depth for sites M2B, M1B, and M4B at Lake Meredith ................. 24

11. Densities and taxonomic composition of major phytoplankton groups collected from site M2B at Lake Meredith on May 1, June 30, August 20, and October 6, 1987 .................. 28

\section{TABLES}

1. Contents of Lake Henry and Lake Meredith for each sampling date ...............................................................

2. Sampling-site locations and sampling dates at Lake Henry and Lake Meredith Reservoir................................ 7

3. Onsite measurements at the Lake Henry inlet (HI) and the Sugar City lateral (HO)..................................... 14

4. Light-transparency measurements for all sites at Lake Henry ................................................................. 15 
5. Average concentrations of dissolved-inorganic nitrogen and dissolved orthophosphate as phosphorus and corresponding ratios for site HEW2 at Lake Henry ........................................................ 16

6. Concentrations of chlorophyll $a$ for site HEW2 at Lake Henry ...................................................................... 17

7. Comparison of fixed-boundary-system values to trophic-variable values for

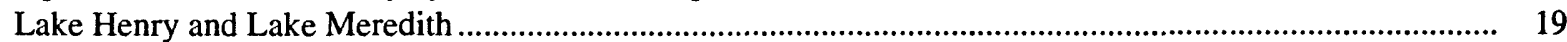

8. Summary of dissolved-oxygen measurements for all sites at Lake Meredith................................................. 23

9. Onsite measurements at the Lake Meredith inlet (MI1) and Bob Creek (MI2) ................................................. 23

10. Light-transparency measurements for all sites at Lake Meredith ................................................................... 25

11. Average concentrations of dissolved-inorganic nitrogen and dissolved orthophosphate as phosphorus and corresponding ratios for site M2B at Lake Meredith.......................................................... 26

12. Concentrations of total-recoverable iron and total-recoverable boron that exceeded the water-quality standards established for Lake Meredith by the Colorado Department of Health (1987) ................................ 26

13. Concentrations of chlorophyll $a$ for sites M2B, M1B, and M4B at Lake Meredith ......................................... 27

14. Trophic-state indices for sites M2B, M1B, and M4B at Lake Meredith....................................................... 29

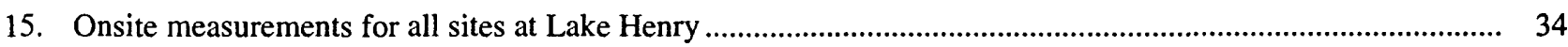

16. Analyses of chemical constituents for site HEW2 at Lake Henry ................................................................. 37

17. Phytoplankton densities for site HEW2 at Lake Henry........................................................................... 39

18. Onsite measurements for all sites at Lake Meredith .......................................................................... 42

19. Analyses of chemical constituents for site M2B at Lake Meredith..............................................................46

20. Analyses of chemical constituents for site M1B at Lake Meredith................................................................4

21. Analyses of chemical constituents for site M4B at Lake Meredith................................................................... 48

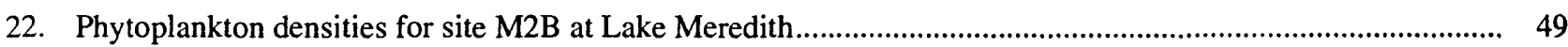

\section{CONVERSION FACTORS AND ABBREVIATED WATER-QUALITY TERMS}

\begin{tabular}{rll}
\hline Multiply & By & To obtain \\
\hline & & \\
acre-foot (acre-ft) & 0.001233 & cubic hectometer \\
foot (ft) & 0.3048 & meter \\
inch (in.) & 25.4 & millimeter \\
liter $(\mathrm{L})$ & 0.2642 & gallon \\
micrometer $(\mu \mathrm{m})$ & 0.00003937 & inch \\
mile $(\mathrm{mi})$ & 1.609 & kilometer \\
\hline
\end{tabular}

Degree Celsius $\left({ }^{\circ} \mathrm{C}\right)$ may be converted to degree Fahrenheit $\left({ }^{\circ} \mathrm{F}\right)$ by using the following equation:

$$
{ }^{\circ} \mathrm{F}=9 / 5\left({ }^{\circ} \mathrm{C}\right)+32 \text {. }
$$

The following terms and abbreviations also are used in this report:

cells per milliliter (cells $/ \mathrm{mL}$ )

microgram per liter $(\mu \mathrm{g} / \mathrm{L})$

microsiemens per centimeter at 25 degrees Celsius $(\mu \mathrm{S} / \mathrm{cm})$

milligram per liter $(\mathrm{mg} / \mathrm{L})$

Sea Level: In this report "sea level" refers to the National Geodetic Vertical Datum of 1929--a geodetic datum derived from a general adjustment of the first-order level nets of the United States and Canada, formerly called Sea Level Datum of 1929. 


\title{
Reconnaissance of Water Quality of Lake Henry and Lake Meredith Reservoir, Crowley County, Southeastern Colorado, April-October 1987
}

\author{
By Joseph R. Sullivan, Jr.
}

\section{Abstract}

Lake Henry and Lake Meredith Reservoir are off-stream storage reservoirs for the Colorado Canal. Water stored in each lake primarily is used for irrigation. Water-quality data were collected from both lakes to assess the physical, chemical, and biological quality of each lake; to compare water-quality data to established standards; to estimate the trophic status of each lake; and to compare the water quality between the two lakes. Onsite measurements of water temperature, dissolved oxygen, $\mathrm{pH}$, specific conductance, and light transparency were made at seven sites in Lake Henry and ten sites in Lake Meredith Reservoir. Onsite measurements of water temperature, dissolved oxygen, $\mathrm{pH}$, and specific conductance were made at the inflow and outflow of Lake Henry and the inflows of Lake Meredith. Water samples were collected near the center of each lake for laboratory analysis of chemical and biological constituents in May, June, August, and October. Additionally, samples were collected near the inflows and outflow of Lake Meredith Reservoir for concentrations of total nutrients, for selected total trace elements, and for chlorophyll $a$ in May, June, and August.

Lake Henry was thermally stratified on May 1 and not stratified on June 29. During the sampling period, dissolved-oxygen concentrations ranged from 4.7 to 7.8 milligrams per liter; the $\mathrm{pH}$ ranged from 8.1 to 8.6. Dissolved-oxygen concentrations and $\mathrm{pH}$ are affected by photosynthesis and respiration. Specific conductance ranged from 889 to 1,010 microsiemens per centimeter but did not vary vertically or areally within the lake.

Secchi-disk measurements were uniform throughout the lake and measured 1.5 feet on May 1 and 0.5 foot during the remainder of the sampling period. Light transparency in Lake Henry is affected by phytoplankton biomass and nonalgal suspended material.

Total-nitrogen concentrations ranged from 0.86 to 1.4 milligrams per liter, and totalphosphorus concentrations ranged from 0.030 to 0.106 milligram per liter during the sampling period. Dissolved-solids concentrations ranged from 598 to 704 milligrams per liter, and calcium and sulfate comprised the largest percentage of the major chemical constituents. Concentrations of total-recoverable iron occasionally exceeded the water-quality standard set for Lake Henry by the Colorado Department of Health. Concentrations of other trace elements were less than the State water-quality standards for Lake Henry or less than the detection limits for the analysis.

Phytoplankton densities in Lake Henry ranged from 33,000 to 930,000 cells per milliliter. Blue-green algae accounted for the greatest percentage of the phytoplankton density. The trophic status of Lake Henry is eutrophic using Secchidisk depth and total phosphorus and is borderline eutrophic using chlorophyll $a$ as indicated by the trophic-state index and is eutrophic as indicated by the fixed-boundary system.

Lake Meredith Reservoir was thermally stratified on May 1 and not stratified on June 30. Dissolved-oxygen concentrations ranged from 1.4 to 10.3 milligrams per liter, and dissolved-oxygen concentrations near the lake bottom on June 30 and August 20 and 21 were less than the waterquality standard. Specific conductance ranged from 2,520 to 3,040 microsiemens per centimeter but did not vary vertically or areally within the lake. Secchi-disk measurements ranged from 0.5 to 1.5 feet and were largest on May 1. Light transparency in Lake Meredith is affected by phytoplankton biomass and nonalgal suspended material. 
Total-nitrogen concentrations were less than 2.0 milligrams per liter, and total-phosphorus concentrations ranged from 0.062 to 0.148 milligram per liter. Dissolved-solids concentrations ranged from 1,870 to 2,370 milligrams per liter, and sodium and sulfate comprised the largest percentage of the major chemical constituents. Concentrations of total-recoverable boron and concentrations of total-recoverable iron occasionally exceeded the water-quality standards set for Lake Meredith Reservoir by the Colorado Department of Health. Concentrations of other trace elements were less than the State water-quality standards for Lake Meredith Reservoir or less than the detection limits for the analysis.

Phytoplankton densities in Lake Meredith Reservoir ranged from 58,000 to $3,900,000$ cells per milliliter. Blue-green algae accounted for the largest percentage of the phytoplankton density. The trophic status of Lake Meredith Reservoir is eutrophic as indicated by the trophic-state index and the fixed-boundary system.

\section{INTRODUCTION}

Lakes and reservoirs in the lower Arkansas River basin in southeastern Colorado historically have been used primarily for storage of irrigation water and for flood control. During the last decade, numerous changes and anticipated changes in land use and in water operations and use in the basin have combined to increase the importance of lake and reservoir water quality. Because the quality of water of lakes and reservoirs can impair water use, there is a need to assess the existing water quality and trophic status of natural lakes and reservoirs in southeastern Colorado. This information is needed to evaluate the suitability of these lakes and reservoirs for existing uses and to serve as a baseline for comparison as changes occur in the basin. However, water quality has not been a major concern in the past, and minimal water-quality data are available for lakes and reservoirs in the area. Additional data are needed for making sound management decisions relative to changes in water use and management and for establishing appropriate in-stream waterquality standards because, as changes in water use and management occur within the basin, the resulting changes in streamflow may affect water quality. Therefore, a study was begun in 1987 by the U.S. Geological Survey, in cooperation with the Southeastern Colorado Water Conservancy District, to determine waterquality conditions of two selected reservoirs in the lower Arkansas River basin that will be used as part of water exchanges by the city of Colorado Springs. Specific objectives of the study were to: (1) Assess the physical, chemical, and biological quality of Lake Henry and Lake Meredith Reservoir; (2) compare physical properties and results of analyses for chemical constituents of the water in these reservoirs with waterquality standards established by the Colorado Department of Health (1987); (3) estimate present trophic status of each reservoir; and (4) compare the water quality between the two reservoirs. Both reservoirs are used as wildlife refuges and provide an important fishery in southeastern Colorado.

\section{Purpose and Scope}

This report describes the water-quality characteristics of Lake Henry and Lake Meredith Reservoir and the comparison between the characteristics and the water-quality standards established for these reservoirs. Lake Meredith Reservoir is locally referred to as Lake Meredith and is hereinafter referred to as Lake Meredith. Measurements of water temperature, dissolved oxygen, $\mathrm{pH}$, specific conductance, and light transparency are reported for numerous sites in each lake. In addition, analyses of samples collected for nutrients (nitrogen and phosphorus), major chemical constituents, trace elements, phytoplankton densities, and chlorophyll $a$ concentrations in Lake Henry and Lake Meredith are included in this report. The report includes a description of some of the water-quality characteristics of each lake, compares the current water quality of Lake Henry and Lake Meredith to the waterquality standards established by the Colorado Department of Health (1987), describes the trophic status of each lake, and compares the water quality between the two lakes. Bathymetric measurements were made at both lakes in April. The onsite measurements and collection of water samples for chemical and biological analyses were done in May, June, August, and October 1987.

\section{Description of Lake Henry and Lake Meredith}

Lake Henry and Lake Meredith are located in Crowley County in southeastern Colorado in an agricultural area of the Arkansas River valley. Lake Henry is about $3 \mathrm{mi}$ northeast of the city of Ordway and Lake Meredith is about 2 mi southeast of the city of Ordway (fig. 1). Both lakes are primarily used as storage reservoirs for irrigation water and water exchanges for the Colorado Canal. Other uses of the lakes include boating and fishing. The city of Colorado Springs is the 


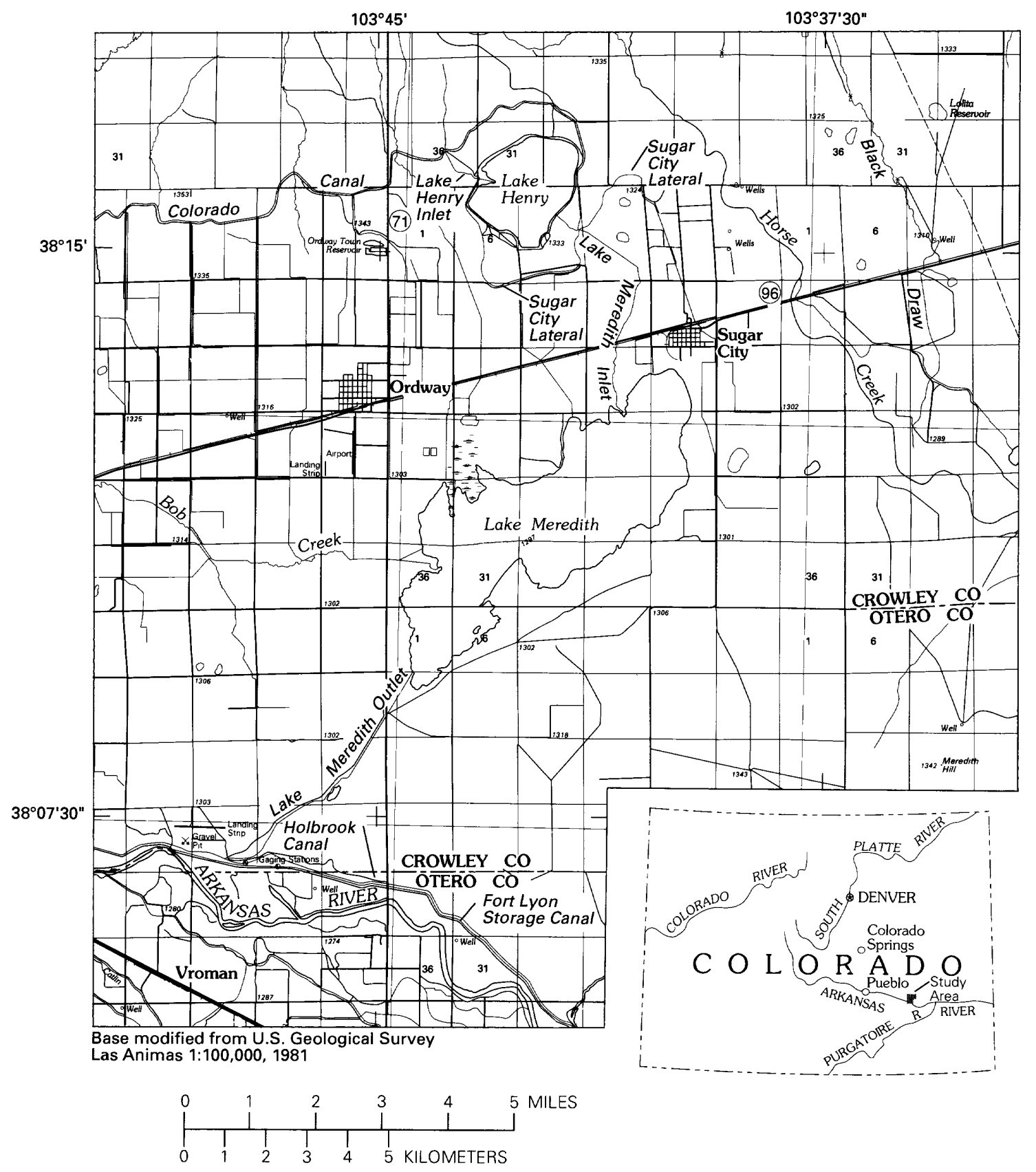

Figure 1. Location of the study area. 
major shareholder in Lake Henry (about 77 percent), Lake Meredith (about 52 percent), and the Colorado Canal (about 56 percent). The remaining shares are owned by other entities.

Water entering Lake Henry is diverted from the Arkansas River by the Colorado Canal about $30 \mathrm{mi}$ west of Ordway. Water is released from Lake Henry into the Sugar City Lateral for irrigation use and also can be diverted from this lateral into the Lake Meredith inlet for storage in Lake Meredith. Lake Meredith also receives water from Bob Creek. Water is stored in Lake Meredith for exchange with the Holbrook Canal, the Fort Lyon Storage Canal, or the Arkansas River (fig. 1). Water from the Lake Meredith outlet can be discharged into both canals. In order to make an exchange, water is released from Lake Meredith and is delivered to the Holbrook Canal, to the Fort Lyon Storage Canal, or to the Arkansas River. The same quantity of water then is diverted from the Arkansas River into the Colorado Canal (Abbott, 1985).

Lake Henry and Lake Meredith are shallow. During the sampling period, the largest depths measured at the time of collection of water samples were $10 \mathrm{ft}$ in Lake Henry and $15 \mathrm{ft}$ in Lake Meredith. A large fluctuation in content occurred in both lakes among the sampling dates-from 7,640 to 2,310 acre-ft in Lake Henry and from 41,380 to 16,920 acre-ft in Lake Meredith. The contents of each lake on the sampling dates are listed in table 1.

Lake Henry and Lake Meredith are classified by the Colorado Department of Health (1987) for class 1 recreation, class 1 warm-water aquatic life, and agriculture. Class 1 recreation is described as water suitable for primary contact where prolonged contact with the body occurs or where small quantities of water may be ingested during recreational activities. Class 1 warm-water aquatic life is described as water suitable

Table 1. Contents of Lake Henry and Lake Meredith for each sampling date

\begin{tabular}{llc}
\hline Lake & $\begin{array}{c}\text { Sampling date, } \\
\mathbf{1 9 8 7}\end{array}$ & $\begin{array}{c}\text { Contents } \\
\text { (acre-feet) }\end{array}$ \\
\hline Henry & May 1 & 7,640 \\
& June 29 & 6,490 \\
& August 19 & 3,560 \\
Meredith & October 6 & 2,310 \\
& May 1 & 38,290 \\
& June 30 & 41,380 \\
& August 20, 21 & 23,210 \\
& October 6 & 16,920 \\
\hline
\end{tabular}

for the protection and maintenance of aquatic-life forms where the water temperature frequently exceeds $20^{\circ} \mathrm{C}$. The agriculture classification is described as water suitable for irrigation of crops and water that is not hazardous as drinking water for livestock (Colorado Department of Health, 1987).

\section{Methods of Investigation}

On April 29-30, 1987, a preliminary reconnaissance of Lake Henry and Lake Meredith was made to select sampling sites (figs. 2 and 3). A depth sounder was used to determine the bathymetry of each lake. Seven sampling sites in Lake Henry and 10 sampling sites in Lake Meredith were selected. Sampling sites on the inflows of each lake and the outflow of Lake Henry also were selected. The outflow of Lake Meredith was not measured because water was not being released on the sampling dates. Each lake was sampled in May, June, August, and October 1987 (table 2).

Onsite measurements of water temperature, dissolved oxygen, $\mathrm{pH}$, specific conductance, and light transparency were made at all sites in each lake on the sampling dates. Water temperature, dissolved oxygen, $\mathrm{pH}$, and specific conductance were measured at 3-ft intervals from the surface to the bottom of the lake using a multiparameter meter. Light transparency was approximated by using a Secchi disk-a white, flat, circular disk about 8 in. in diameter. The light-transparency measurements were made by recording the depth to the nearest $0.5 \mathrm{ft}$ at which the Secchi disk disappeared from view. The depth approximated by the use of the Secchi disk is referred to as the Secchi-disk depth. Water temperature, dissolved oxygen, $\mathrm{pH}$, and specific conductance also were measured at the inflows of each lake and the outflow of Lake Henry (table 2).

Water samples were collected near the center of each lake for laboratory analysis of chemical and biological constituents. Samples for chemical analysis were collected near the lake surface and near the lake bottom using a 4-L, 2-ft-long, polyethylene, watersampling bottle. In addition, water samples were collected near the inflows and outflow of Lake Meredith for analyses of concentrations of total nutrients, selected total trace elements, and chlorophyll $a$. Procedures used for collection, preservation, and analysis of water samples are discussed in Brown and others (1970), Fishman and Friedman (1985), and Britton and Greeson (1989). Chemical constituents were analyzed at the U.S. Geological Survey National Water-Quality Laboratory in Arvada, Colorado. 

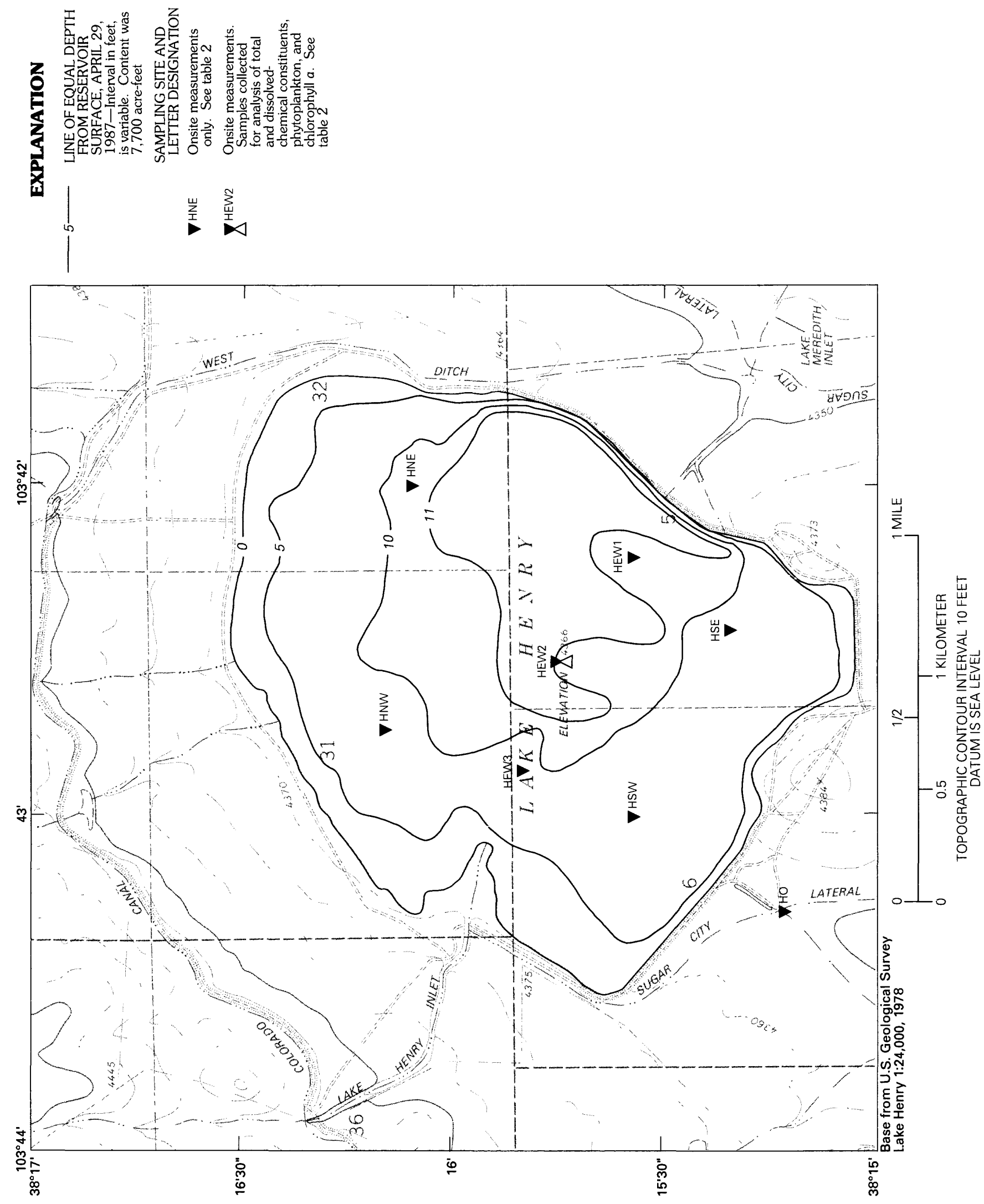

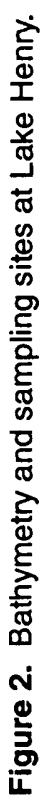




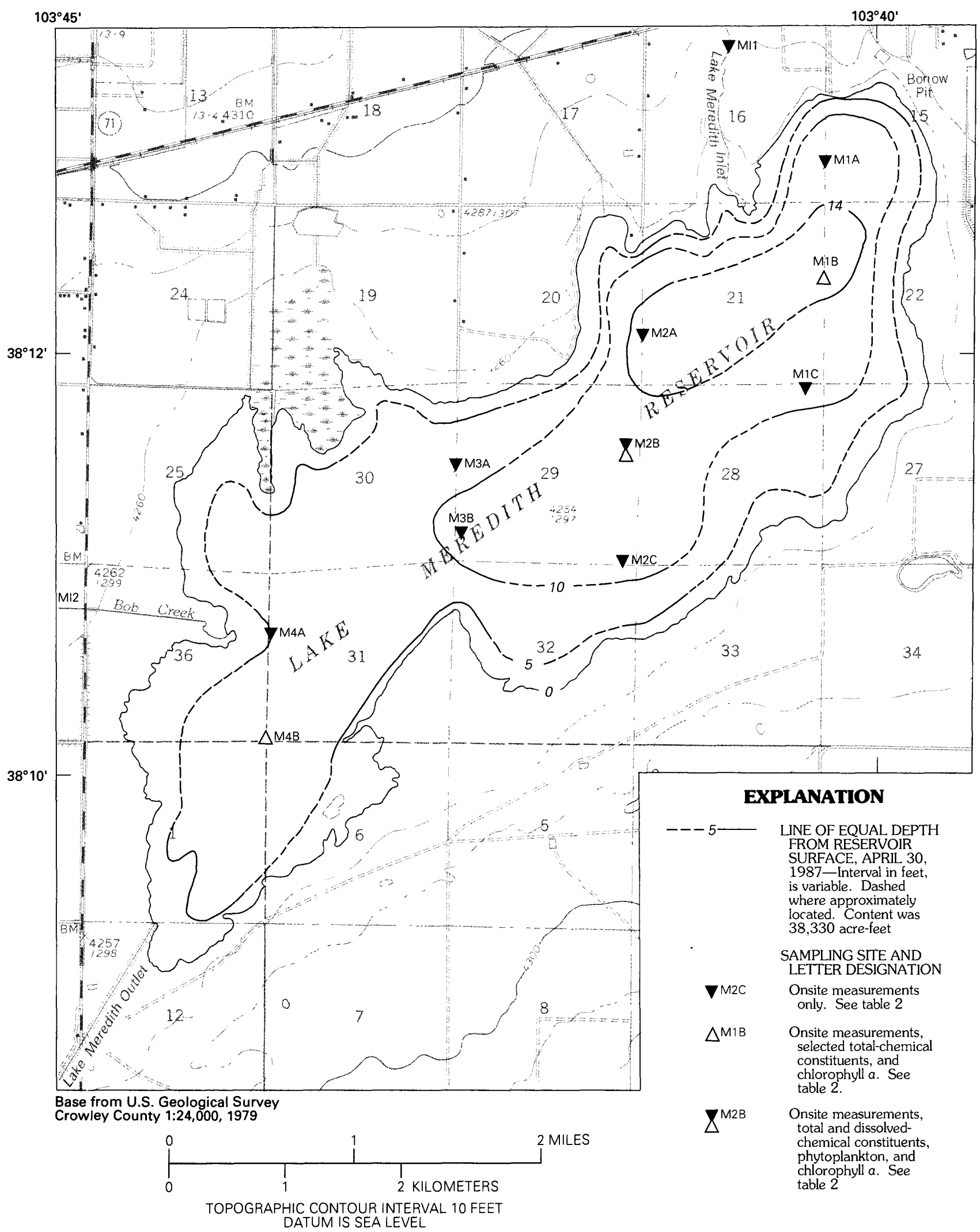

Figure 3. Bathymetry and sampling sites at Lake Meredith. 
Table 2. Sampling-site locations and sampling dates at Lake Henry and Lake Meredith Reservoir

\begin{tabular}{|c|c|c|c|}
\hline \multirow{2}{*}{ Sampling site } & \multicolumn{2}{|c|}{ Location } & \multirow{2}{*}{$\begin{array}{c}\text { Sampling date, } \\
1987\end{array}$} \\
\hline & Latitude & Longitude & \\
\hline \multicolumn{4}{|c|}{ Lake Henry (fig. 2) } \\
\hline HEW2 & $38^{\circ} 15^{\prime} 43^{\prime \prime}$ & $103^{\circ} 42^{\prime} 33^{\prime \prime}$ & $5-1,6-29,8-19,10-6$ \\
\hline HNW & $38^{\circ} 16^{\prime} 11^{\prime \prime}$ & $103^{\circ} 42^{\prime} 36^{\prime \prime}$ & $5-1,6-29,8-19$ \\
\hline HSE & $38^{\circ} 15^{\prime} 34^{\prime \prime}$ & $103^{\circ} 42^{\prime} 25^{\prime \prime}$ & $5-1,6-29,8-19$ \\
\hline HEW1 & $38^{\circ} 15^{\prime} 34^{\prime \prime}$ & $103^{\circ} 42^{\prime} 14^{\prime \prime}$ & $5-1,6-29,8-19$ \\
\hline HEW3 & $38^{\circ} 15^{\prime} 51^{\prime \prime}$ & $103^{\circ} 42^{\prime} 53^{\prime \prime}$ & $5-1,6-19,8-19$ \\
\hline HNE & $38^{\circ} 16^{\prime} 08^{\prime \prime}$ & $103^{\circ} 41^{\prime} 00^{\prime \prime}$ & $5-1,6-29,8-19$ \\
\hline HSW & $38^{\circ} 15^{\prime} 37^{\prime \prime}$ & $103^{\circ} 43^{\prime} 05^{\prime \prime}$ & $5-1,6-29,8-19$ \\
\hline${ }^{1} \mathrm{HI}$ & $38^{\circ} 15^{\prime} 58^{\prime \prime}$ & $103^{\circ} 43^{\prime} 19^{\prime \prime}$ & $6-29,8-19$ \\
\hline${ }^{2} \mathrm{HO}$ & $38^{\circ} 15^{\prime} 14^{\prime \prime}$ & $103^{\circ} 43^{\prime} 14^{\prime \prime}$ & $5-1,6-29,8-19,10-6$ \\
\hline \multicolumn{4}{|c|}{ Lake Meredith Reservoir (fig. 3) } \\
\hline $\mathrm{M} 2 \mathrm{~B}$ & $38^{\circ} 11^{\prime} 40^{\prime \prime}$ & $103^{\circ} 41^{\prime} 31^{\prime \prime}$ & $5-1,6-30,8-20,10-6$ \\
\hline M1B & $38^{\circ} 12^{\prime} 39^{\prime \prime}$ & $103^{\circ} 40^{\prime} 24^{\prime \prime}$ & $5-1,6-30,8-20$ \\
\hline M4B & $38^{\circ} 10^{\prime} 18^{\prime \prime}$ & $103^{\circ} 43^{\prime} 45^{\prime \prime}$ & $5-1,6-30,8-21$ \\
\hline M1A & $38^{\circ} 12^{\prime} 59^{\prime \prime}$ & $103^{\circ} 40^{\prime} 25^{\prime \prime}$ & $6-30,8-20$ \\
\hline $\mathrm{M} 1 \mathrm{C}$ & $38^{\circ} 11^{\prime} 58^{\prime \prime}$ & $103^{\circ} 40^{\prime} 24^{\prime \prime}$ & $6-30,8-20$ \\
\hline $\mathrm{M} 2 \mathrm{~A}$ & $38^{\circ} 12^{\prime} 11^{\prime \prime}$ & $103^{\circ} 41^{\prime} 30^{\prime \prime}$ & $6-30,8-20$ \\
\hline $\mathrm{M} 2 \mathrm{C}$ & $38^{\circ} 11^{\prime} 10^{\prime \prime}$ & $103^{\circ} 41^{\prime} 31^{\prime \prime}$ & $6-30,8-20$ \\
\hline M3A & $38^{\circ} 11^{\prime} 37^{\prime \prime}$ & $103^{\circ} 42^{\prime} 37^{\prime \prime}$ & $6-30,8-21$ \\
\hline M3B & $38^{\circ} 11^{\prime} 17^{\prime \prime}$ & $103^{\circ} 42^{\prime} 37^{\prime \prime}$ & $6-30,8-21$ \\
\hline M4A & $38^{\circ} 10^{\prime} 18^{\prime \prime}$ & $103^{\circ} 43^{\prime} 45^{\prime \prime}$ & $6-30,8-21$ \\
\hline${ }^{1} \mathrm{MI} 1$ & $38^{\circ} 13^{\prime} 46^{\prime \prime}$ & $103^{\circ} 41^{\prime} 01^{\prime \prime}$ & $6-30,8-21$ \\
\hline${ }^{1} \mathrm{MI} 2$ & $38^{\circ} 10^{\prime} 55^{\prime \prime}$ & $103^{\circ} 44^{\prime} 50^{\prime \prime}$ & $6-30,8-20,10-6$ \\
\hline
\end{tabular}

Water samples for phytoplankton analysis were collected using the water-sampling bottle from a single depth near the lake surface. A 1-L sample was preserved using a 37-percent formaldehyde solution. The phytoplankton count was determined by transferring a known part of the sample to a settling chamber and was examined using a 200 to 1,000 power inverted microscope. The chlorophyll $a$ samples were collected from a single depth near the lake surface and from a single depth near the lake bottom using the water-sampling bottle. One to two liters of a sample were filtered through a $0.45 \mu \mathrm{m}$, cellulose-acetate filter. The filter then was placed in a petri dish, wrapped in aluminum foil, and frozen using dry ice. The chlorophyll $a$ analysis was performed by placing the sample in a 90 -percent-aqueous acetone solution. The mixture was steeped in the dark for 24 hours at $4^{\circ} \mathrm{C}$ then centrifuged for $20 \mathrm{~min}$. The supernatant was decanted into stoppered cuvettes and was analyzed with a spectrophotometer (Chadwick and Associates, Littleton, Colorado, written commun., 1985). The phytoplankton and chlorophyll $a$ analyses were done by a private laboratory.

For this study, two trophic-classification systems were used for comparison to assign a relative trophic status to Lake Henry and Lake Meredith. The first system used was the trophic-state index (TSI) developed by Carlson (1977), which categorizes lakes using a 
scale of 0 to 100 ( 0 indicating almost no biomass for chlorophyll). This index can be estimated using summer values of Secchi-disk depth (SD) and summer surface values of total-phosphorus concentration (TP) and chlorophyll $a$ concentration $(\mathrm{Chl})$. These variables, when transformed to the trophic scale, should have the same or nearly the same value. However, a divergence of one or more variables from this value may indicate a need to further study the relations among various components of the lake or reservoir (Carlson, 1977). The best variable ( $\mathrm{SD}, \mathrm{TP}$, or $\mathrm{Chl}$ ) for determining trophic state may vary from lake to lake and may also vary seasonally within a lake.

Because variations in the TSI values between $\mathrm{SD}, \mathrm{TP}$, and $\mathrm{Chl}$ can provide valuable information about a lake, all three variables were used to calculate the trophic-scale values for Lake Henry and Lake Meredith. The trophic-state index was calculated for the three variables using the following equations:

$$
\begin{gathered}
\text { TSI }(\mathrm{SD})=10\left(6-\frac{\ln \mathrm{SD}}{\ln 2}\right) \\
\operatorname{TSI}(\mathrm{TP})=10\left(6-\frac{\ln \frac{48}{\mathrm{TP}}}{\ln 2}\right) \\
\operatorname{TSI}(\mathrm{Chl})=10\left(6-\frac{2.04-0.68 \ln \mathrm{Chl}}{\ln 2}\right)
\end{gathered}
$$

where SD is expressed in meters, TP and Chl are expressed in micrograms per liter, and $\ln$ is the natural logarithm.

The second trophic-classification system used was the fixed-boundary system developed by the Organisation for Economic Co-operation and Development (OECD) (1982). This system attempts to relate specific boundary values for minimum and mean Secchi-disk depth, mean total-phosphorus concentration, and peak and mean chlorophyll $a$ concentration to the descriptive trophic terms oligotrophic, eutrophic, and mesotrophic. The fixed-boundary system is based on opinions of a large group of limnologists from around the world who participated in the OECD program.

\section{SIGNIFICANCE OF WATER-QUALITY VARIABLES}

The physical, chemical, and biological relations in lakes are dynamic. The value of any one property or constituent is affected by the others. The following sections present a general explanation of the physical, chemical, and biological constituents determined during the study.

\section{Onsite Measurements}

The onsite measurements made for water temperature, dissolved oxygen, $\mathrm{pH}$, specific conductance, and light transparency are easily done and serve as a guide for the collection of other water-quality data.

Water temperature affects the physical, chemical, and biological processes that occur in lakes. For example, the solubility of dissolved oxygen is inversely related to temperature; at warmer water temperatures, less oxygen can be dissolved in the water. Temperature also has a direct effect on the density of water. As water temperatures become lesser or greater than $4^{\circ} \mathrm{C}$, the density decreases. Stratification of lakes occurs when less dense water overlies more dense water. Stratification inhibits the mixing of waters of different densities and may result in a difference in the water quality of the water layers.

Dissolved oxygen is necessary for maintaining aquatic life. The dissolved-oxygen concentration is affected by water temperature, barometric pressure, the physical interaction of the water with the atmosphere (aeration), photosynthesis and respiration, and decompositional processes. Phytoplankton and other plants in the water release oxygen during photosynthesis and consume oxygen during respiration. The concentrations of dissolved oxygen may become depleted if respiration exceeds the rate at which oxygen is replaced. Stratification may prevent transfer of dissolved oxygen from the surface water to underlying water, which may then become anoxic.

The solubility of many chemical constituents and the biological activity of many organisms are $\mathrm{pH}$ dependent. The $\mathrm{pH}$ of lake water commonly is affected by photosynthesis and respiration. The use of carbon dioxide during photosynthesis increases the $\mathrm{pH}$, and the release of carbon dioxide during respiration decreases the $\mathrm{pH}$.

Specific conductance is a measure of the ability of water to conduct an electrical current and generally is used to approximate the dissolved-solids concentration of water. As the concentration of dissolved solids increases, specific conductance increases. Because of this relation, concentrations of the individual major chemical constituents may be estimated from the specific conductance.

Light transparency is the ability of water to transmit light and determines the depths at which sufficient light is available for photosynthesis. When light intensity is decreased to about 1 percent of its intensity at the 
surface, oxygen production by photosynthesis approximately equals oxygen consumption by respiration.

\section{Chemical Constituents}

The chemical quality of water in lakes is determined by the presence and concentrations of various chemical constituents. These constituents consist of dissolved and suspended minerals, gases, and organic compounds. The chemical constituents discussed in this report include the nutrients nitrogen and phosphorus, major chemical constituents, and trace elements.

Nitrogen and phosphorus are nutrients essential for the growth and production of plants. They are consumed by phytoplankton and if their concentrations become too small, plant growth is limited. Nutrients naturally enter a lake from rainfall, ground-water inflow, streamflow, and runoff. An increase in nutrient loads to a lake can result from the discharge of treated municipal wastewater and the application of fertilizers on agricultural land that drains into the lake. Nitrate and ammonia are the forms of nitrogen most easily utilized by algae, but ammonia, where present in sufficient quantities, is more readily used by plants for growth. Phosphate is the primary form of phosphorus utilized by phytoplankton (Goldman and Horne, 1983).

The major chemical constituents comprise most of the dissolved solids that commonly occur in water. They consist of the cations-calcium, magnesium, sodium, potassium, and anions-bicarbonate, sulfate, chloride, and fluoride. The concentrations of the major chemical constituents are affected by rainwater and by the solution of minerals in the drainage basin upstream from the lake. However, irrigation return flows and wastewater discharge may add substantial quantities of the constituents to lake water, and evaporation can concentrate the constituents already present.

Trace elements are those substances in water that generally occur in concentrations less than $1 \mathrm{mg} / \mathrm{L}$. However, the presence of some trace elements in large quantities may cause toxic effects on the biota. The concentrations of trace elements in lake water are affected by input from rivers, release from sediments, and uptake by the phytoplankton. These constituents commonly are transported with sediment and settle to the lake bottom. When anoxic conditions occur in the bottom sediments, the trace elements may dissolve and migrate upward toward the overlying water and may be released into the water.

\section{Biological Constituents}

Each lake is regarded as an ecosystem and contains a variety of organisms. The numbers and kinds of organisms present in a lake give an indication of waterquality conditions. A change in the water quality of a lake can have a direct effect on aquatic life.

The organisms that drift passively with the water currents are called plankton. Phytoplankton or algae are the plant portion of plankton. Phytoplankton are important as primary producers in lakes and are used as a food source by zooplankton (the animal portion of plankton) and fish. Through photosynthesis, phytoplankton are a principal source of oxygen on which all animal aquatic life depends (McCoy, 1982). The phytoplankton population is dependent on the waterquality conditions of a lake. Given adequate sunlight, warm-water temperatures, and sufficient nutrients, algae may reproduce quickly, creating an algal bloom. This accumulation of visible, unattached algae near the lake surface can cause numerous problems in a lake. As a result of overproduction, nutrients are depleted, and large numbers of algae may die. The resulting algal decomposition may decrease concentrations of dissolved oxygen resulting in fish kills.

Chlorophyll $a$ is present in all algae and is the primary photosynthetic pigment of all oxygenproducing photosynthetic organisms (Wetzel, 1975). Chlorophyll $a$ is necessary in the production of chemical energy for photosynthesis and growth. The measurement of chlorophyll $a$ is an indicator of the concentration of algae present in a lake and is used in determining trophic status.

\section{Trophic Status}

The terms oligotrophic, eutrophic, and mesotrophic are used to classify lakes and reservoirs. Oligotrophic water bodies are characterized by small nutrient concentrations and a small level of productivity. Eutrophic water bodies have large nutrient concentrations and a large level of productivity. The term mesotrophic is used to describe water bodies in transition between oligotrophic and eutrophic (Ryding, 1988). However, there is not universal agreement among limnologists regarding trophic boundaries. A particular value for a given water-quality variable might indicate an oligotrophic state to one limnologist and mesotrophic state to another limnologist. Also, a lake or reservoir might be classified as oligotrophic on the basis of one variable and as mesotrophic on the basis of another variable. 


\section{WATER-QUALITY CHARACTERISTICS OF LAKE HENRY AND COMPARISON TO WATER-QUALITY STANDARDS}

Water-quality characteristics of Lake Henry were determined by onsite measurements made at seven sites in the lake and by laboratory analysis for selected chemical and biological constituents in water samples collected at site HEW2 (fig. 2). Physical properties and results of analyses for chemical constituents were compared with water-quality standards established by the Colorado Department of Health.

\section{Onsite Measurements}

The water-temperature profiles shown in figure 4 are representative of the thermal characteristics that existed in Lake Henry on the sampling dates. The temperatures in the lake ranged from $14.2^{\circ} \mathrm{C}$ at a depth of $5 \mathrm{ft}$ at site HEW2 on October 6 to $26.4^{\circ} \mathrm{C}$ at the water surface at site HNE on August 19 (table 15, "Supplemental Data" section at the back of this report). Watertemperature measurements on May 1 indicate that the lake was thermally stratified at all sites because of spring warming of the upper water layer. Variations of surface temperatures between sites are attributed to time of measurement. Water temperatures at the surface were cooler earlier in the day than those measured later in the day due to heating from solar radiation. On June 29 , water temperatures were uniform vertically and areally throughout the lake indicating the lake was not thermally stratified. On August 19, water temperatures decreased with depth; at sites HEW2, HNW, and HSW water temperatures measured near the bottom of the lake were cooler than water temperatures measured near the bottom of the lake on June 29. This apparent anomaly may be because of the 4-ft decline in reservoir elevation between June 29 and August 19. This decline may have allowed cooler ground water to mix with the water near the bottom of the lake.

The dissolved-oxygen and $\mathrm{pH}$ profiles shown in figure 5 varied similarly with depth, indicating that dissolved-oxygen concentrations and $\mathrm{pH}$ are affected by photosynthesis and respiration. During periods when photosynthesis predominates, oxygen is produced by algae, which increases dissolved-oxygen concentrations, and carbon dioxide is used by algae, which increases the $\mathrm{pH}$. Conversely, during periods of respiration, the use of oxygen by algae decreases the dissolved-oxygen concentration, and the release of carbon dioxide decreases the $\mathrm{pH}$.

Dissolved-oxygen concentrations in Lake Henry are affected by photosynthesis and respiration, reaera- tion, and water temperature. Dissolved-oxygen concentrations in the lake ranged from $4.7 \mathrm{mg} / \mathrm{L}$ at the lake bottom at site HNW on August 19 to $7.8 \mathrm{mg} / \mathrm{L}$ at the lake surface and at the 3-ft depth at site HEW2 on October 6 (table 15). On May 1, Lake Henry was thermally stratified, and a density barrier prevented transfer of dissolved oxygen from the surface-water layer to the lake bottom resulting in a stratification of dissolved oxygen. On June 29 , the lake was nearly isothermal, and only slight changes in dissolved-oxygen concentrations with depth were measured. As a result of warmer water temperatures on June 29, concentrations of dissolved oxygen were smaller than on May 1. Probably because of increased biological activity on August 19, the largest dissolved-oxygen concentrations were measured at the lake surface due to photosynthesis, and dissolved-oxygen concentrations decreased with depth due to respiration. On October 6, increased dissolved-oxygen concentrations probably are a result of cooler water temperatures.

A minimum allowable dissolved-oxygen concentration of $5.0 \mathrm{mg} / \mathrm{L}$ has been established for Lake Henry by the Colorado Department of Health (1987). The $4.7 \mathrm{mg} / \mathrm{L}$ dissolved-oxygen concentration measured on August 19 at site HNW at the lake bottom was the only measurement less than the State standard for class 1 warm-water aquatic life and agriculture.

The $\mathrm{pH}$ of water in Lake Henry is affected by water that enters the lake from the Lake Henry inlet (table 3) and by photosynthesis and respiration. The $\mathrm{pH}$ of water in the lake ranged from 8.1 to 8.6 on the sampling dates (table 15). Generally, larger $\mathrm{pH}$ values were measured near the lake surface because of photosynthesis, and smaller $\mathrm{pH}$ values were measured near the lake bottom where respiration predominates. On May 1, the $\mathrm{pH}$ tended to increase from the lake surface to about the middle depths and then decrease to the lake bottom (fig. 5). This was possibly because of a concentration of phytoplankton at the top of the density barrier caused by thermal stratification. On June 29, the lake was not stratified, and $\mathrm{pH}$ varied slightly from the lake surface to the lake bottom. The $\mathrm{pH}$ on June 29 generally was smaller than on the other sampling dates, which indicated that less biological activity occurred at this time. The allowable range of $\mathrm{pH}$ established for Lake Henry by the Colorado Department of Health (1987) is 6.5 to 9.0 , and the measured $\mathrm{pH}$ values in the lake during the sampling period were within this range.

Profiles of specific conductance indicate there was minimal vertical and areal variation in measured values (fig. 6). Variations in specific conductance ranging from $889 \mu \mathrm{S} / \mathrm{cm}$ on June 29 to $1,010 \mu \mathrm{S} / \mathrm{cm}$ on October 6 were measured during the sampling period (table 15). A decrease in specific conductance of about 


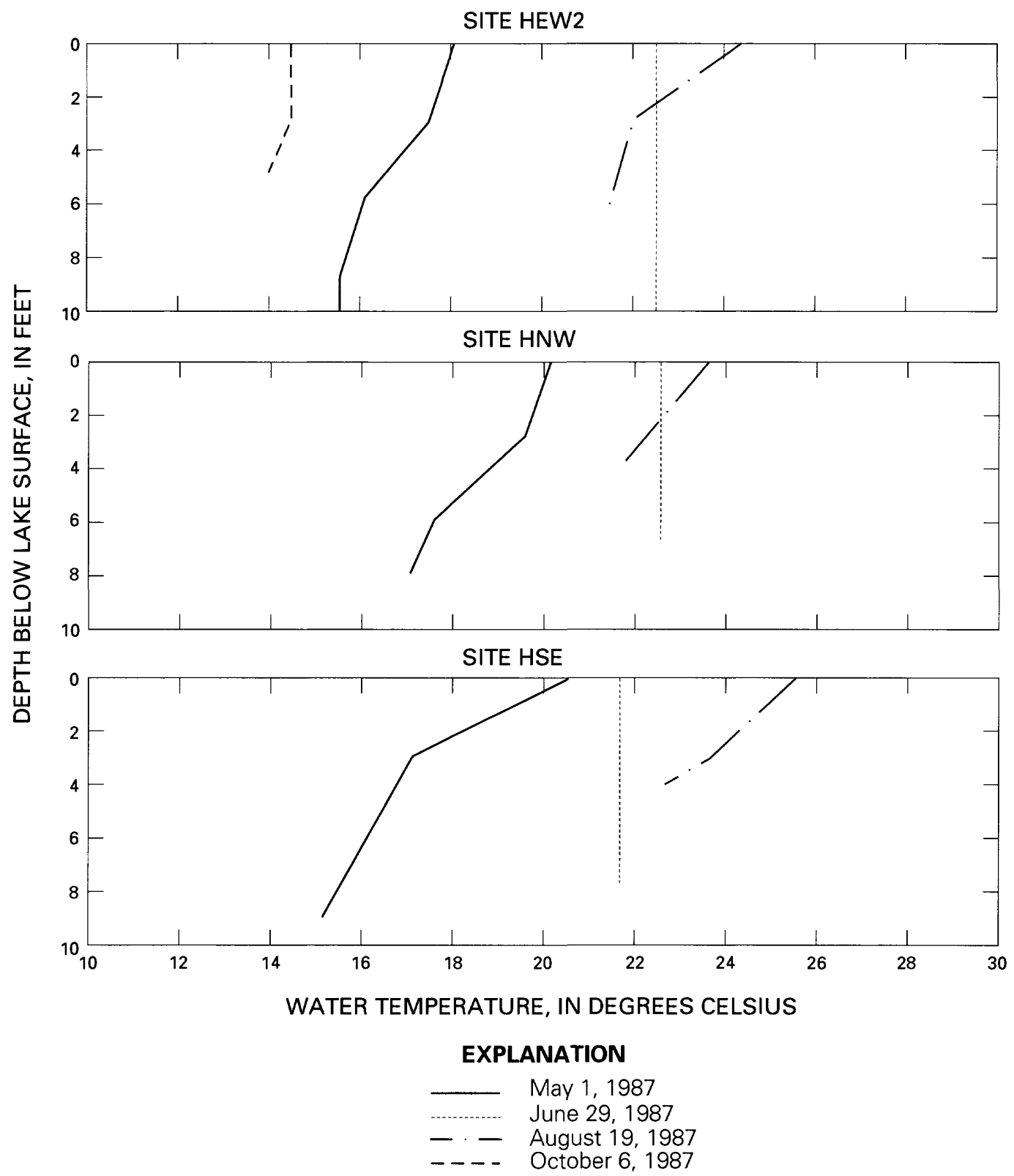

Figure 4. Profiles of water temperature at depth for sites HEW2, HNW, and HSE at Lake Henry. 
SITE HEW2
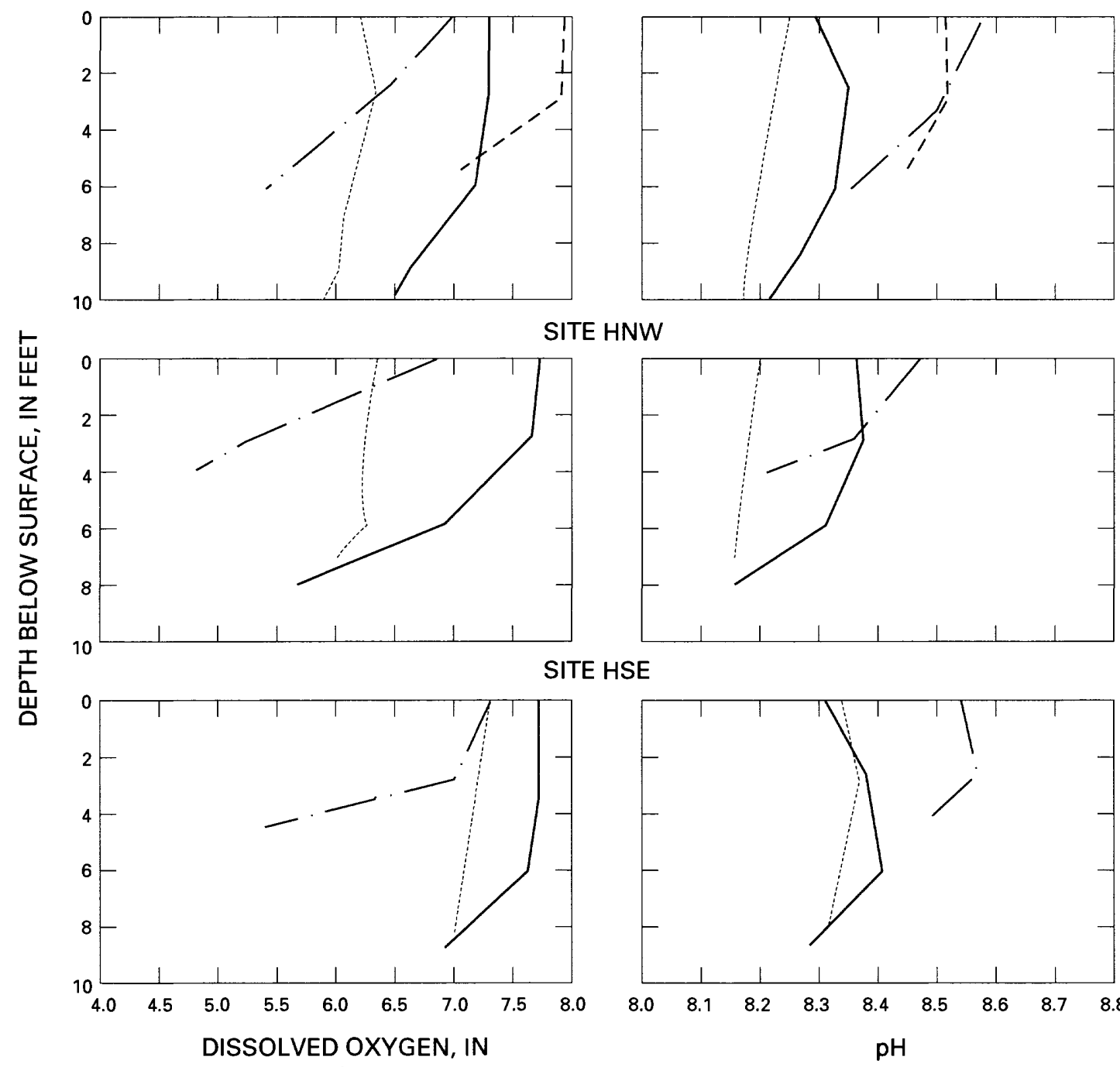

ITE HNW

MILLIGRAMS PER LITER

\section{EXPLANATION}

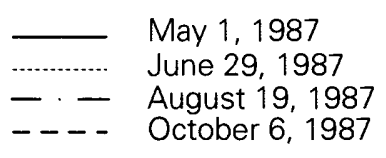

Figure 5. Profiles of dissolved oxygen and pH at depth for sites HEW2, HNW, and HSE at Lake Henry. 


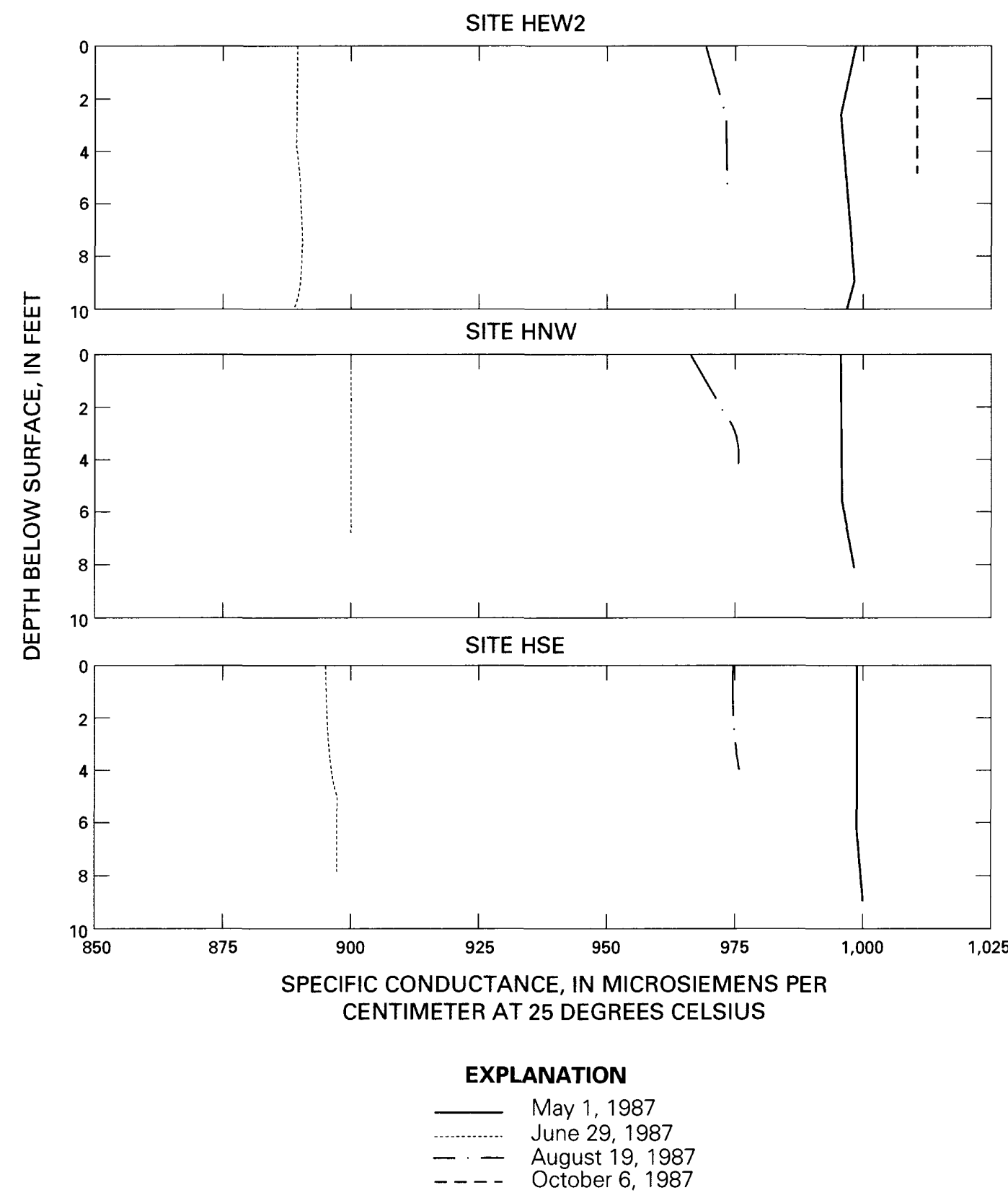

Figure 6. Profiles of specific conductance at depth for sites HEW2, HNW, and HSE at Lake Henry. 
10 percent between the May and June sampling dates probably was caused by dilution from inflowing water. Between the May and June sampling dates, water from the Colorado Canal (fig. 1) was diverted into the lake. On May 1, the mean specific conductance in the lake was $995 \mu \mathrm{S} / \mathrm{cm}$. On June 29 , the specific conductance measured at site HI was $468 \mu \mathrm{S} / \mathrm{cm}$ (table 3 ), and the mean specific conductance for the lake had decreased to $896 \mu \mathrm{S} / \mathrm{cm}$. On August 19, the mean specific conductance in the lake had increased to $974 \mu \mathrm{S} / \mathrm{cm}$. The specific conductance in Lake Henry increased again between the August and October sampling dates. On October 6, there was no inflow to the lake; the lack of inflow combined with a large concentration of dissolved solids due to evaporation may account for the larger specific conductance measured on October 6.

In general, Secchi-disk depths were uniform throughout the lake. On May 1, the Secchi-disk measurements were $1.5 \mathrm{ft}$ at all sites except site HEW3, which was $0.5 \mathrm{ft}$. On the other sampling dates, the Secchi-disk measurements were $0.5 \mathrm{ft}$ at all sites (table 4). Light transparency in Lake Henry probably is most affected by phytoplankton biomass; however, suspended sediments from the inflow and disturbed bottom sediments from wave action also could decrease light transparency.

Table 3. Onsite measurements at the Lake Henry inlet $(\mathrm{HI})$ and the Sugar City lateral (HO)

$\left[{ }^{\circ} \mathrm{C}\right.$, degrees Celsius; $\mathrm{mg} / \mathrm{L}$, milligrams per liter; $\mu \mathrm{S} / \mathrm{cm}$, microsiemens per centimeter at 25 degrees Celsius; dashes indicate no measurement]

\begin{tabular}{cccccc}
\hline $\begin{array}{c}\text { Sampling site } \\
\text { (fig. 2) }\end{array}$ & $\begin{array}{c}\text { Sampling date, } \\
\mathbf{1 9 8 7}\end{array}$ & $\begin{array}{c}\text { Water } \\
\text { temperature } \\
\left({ }^{\circ} \mathbf{C}\right)\end{array}$ & $\begin{array}{c}\text { Dlssolved oxygen } \\
(\mathbf{m g} / \mathbf{L})\end{array}$ & $\mathrm{pH}$ & $\begin{array}{c}\text { Specific } \\
\text { conductance } \\
(\boldsymbol{\mu} \mathbf{S} / \mathbf{c m})\end{array}$ \\
\cline { 2 - 6 } H1 & $05-01$ & -- & -- & -- & -- \\
& $06-29$ & 20.6 & 7.0 & 8.1 & 468 \\
& $08-19$ & 27.0 & 5.1 & 8.2 & 571 \\
& $10-06$ & -- & -- & -- & - \\
HO & & & & 8.3 & 1,000 \\
& $05-01$ & 19.2 & 7.8 & 8.3 & 879 \\
& $06-29$ & 22.9 & 6.8 & 8.4 & 980 \\
& $08-19$ & 21.6 & 6.4 & 8.5 & 996 \\
\hline
\end{tabular}


Table 4. Light-transparency measurements for all sites at Lake Henry

\begin{tabular}{ccc}
\hline $\begin{array}{c}\text { Sampling site } \\
\text { (fig. 2) }\end{array}$ & $\begin{array}{c}\text { Sampling date, } \\
\mathbf{1 9 8 7}\end{array}$ & $\begin{array}{c}\text { Secchl-disk } \\
\text { depth } \\
\text { (feet) }\end{array}$ \\
\hline${ }^{2}$ HEW2 & $05-01$ & 1.5 \\
& $06-29$ & .5 \\
& $08-19$ & .5 \\
HNW & $10-06$ & .5 \\
& $05-01$ & 1.5 \\
& $06-29$ & .5 \\
HSE & $08-19$ & .5 \\
& $05-01$ & 1.5 \\
& $06-29$ & .5 \\
HEW1 & $08-19$ & .5 \\
& $05-01$ & 1.5 \\
& $06-29$ & .5 \\
HEW3 & $08-19$ & .5 \\
& $05-01$ & .5 \\
& $06-29$ & .5 \\
HNE & $08-19$ & .5 \\
& $05-01$ & 1.5 \\
& $06-29$ & .5 \\
HSW & $08-19$ & .5 \\
& $05-01$ & 1.5 \\
& $06-29$ & .5 \\
& $08-19$ & .5 \\
\hline
\end{tabular}

\footnotetext{
Light transparency represents the depth to the nearest 0.5 foot at which the Secchi disk was not visible.

${ }^{2} \mathrm{HEW} 2$ was the only site measured on October 6, 1987.
}

\section{Chemical Constituents}

During the sampling period, total-nitrogen concentrations at site HEW2 in Lake Henry ranged from 0.86 to $1.4 \mathrm{mg} / \mathrm{L}$ and averaged about $1.1 \mathrm{mg} / \mathrm{L}$ (table 16 , "Supplemental Data" section at the back of this report). The principal nitrogen form was organic nitrogen, which averaged about 86 percent of the total nitrogen. Organic nitrogen is less biologically available than are the inorganic forms of nitrogen (ammonia, nitrite, and nitrate). The concentrations of total-inorganic nitrogen (ammonia plus nitrite plus nitrate) were less than $0.2 \mathrm{mg} / \mathrm{L}$ throughout the sampling period.
The Colorado Department of Health (1987) has established a water-quality standard for aquatic life of $0.5 \mathrm{mg} / \mathrm{L}$ of total nitrite and $0.06 \mathrm{mg} / \mathrm{L}$ of un-ionized ammonia for Lake Henry. In greater concentrations, these two forms of nitrogen can be toxic to fish. Totalnitrite concentrations at site HEW2 ranged from 0.003 to $0.012 \mathrm{mg} / \mathrm{L}$, as nitrogen. Un-ionized ammonia is calculated as a percentage of total ammonia, given water temperature and $\mathrm{pH}$ (Willingham, 1976). The percentage of total ammonia that would exist as unionized ammonia increases as water temperature and $\mathrm{pH}$ increase. Calculated un-ionized-ammonia concentrations ranged from 0 to $0.008 \mathrm{mg} / \mathrm{L}$.

During the sampling period, total phosphorus concentrations in Lake Henry ranged from 0.030 to $0.106 \mathrm{mg} / \mathrm{L}$ and averaged about $0.066 \mathrm{mg} / \mathrm{L}$. The biologically available form of phosphorus is orthophosphate, which averaged about 26 percent of the total phosphorus.

According to Ryding (1988), the biologicallyavailable nutrients are better approximated by dissolved-inorganic nitrogen and dissolved orthophosphate as phosphorus. Concentrations of dissolvedinorganic nitrogen less than $0.02 \mathrm{mg} / \mathrm{L}$ indicate possible nitrogen limitation, and concentrations of dissolved orthophosphate as phosphorus less than 0.005 to $0.010 \mathrm{mg} / \mathrm{L}$ indicate possible phosphorus limitation (Ryding, 1988). During the sampling period, concentrations of dissolved-inorganic nitrogen, averaged for the two sampling depths at site HEW2, ranged from less than 0.034 to $0.219 \mathrm{mg} / \mathrm{L}$ (table 5). Concentrations of dissolved orthophosphate as phosphorus, averaged for the two sampling depths at site HEW2, ranged from less than 0.001 to $0.037 \mathrm{mg} / \mathrm{L}$. The concentrations of dissolved-inorganic nitrogen and dissolved orthophosphate as phosphorus listed in table 5 indicate that phosphorus was potentially limiting on May 1, June 29, and August 19. On October 6, neither nitrogen nor phosphorus was potentially limiting.

The ratio of nitrogen to phosphorus also may be used to determine which nutrient may limit algal growth in a lake. A mass ratio of dissolved-inorganic nitrogen to dissolved orthophosphate as phosphorus of 7.2:1 has been used as a boundary for defining the limiting nutrient. If the ratio is less than about $7: 1$, nitrogen may be the limiting nutrient; if the ratio is greater than 7:1, phosphorus may be limiting (Ryding, 1988). The ratios listed in table 5 indicate potential phosphorus limitation in Lake Henry on May 1, June 29, and August 19 and potential nitrogen limitation on October 6. 
Table 5. Average concentrations of dissolved-inorganic nitrogen and dissolved orthophosphate as phosphorus and corresponding ratios for site HEW2 at Lake Henry

[mg/L, milligrams per liter; <, less than]

\begin{tabular}{lccc}
\hline $\begin{array}{c}\text { Sampling date, } \\
\mathbf{1 9 8 7}\end{array}$ & $\begin{array}{c}\text { Dissolved-inorganic nitrogen } \\
(\mathbf{m g} / \mathrm{L})\end{array}$ & $\begin{array}{c}\text { Dissolved orthophosphate } \\
\text { as phosphorus } \\
\text { (mg/L) }\end{array}$ & $\begin{array}{c}\text { Ratio of dissoived-inorganic } \\
\text { nitrogen to dissoived } \\
\text { orthophosphate as } \\
\text { phosphorus }\end{array}$ \\
\hline May 1 & 0.170 & $<0.001$ & $<170: 1$ \\
June 29 & .219 & .002 & $110: 1$ \\
August 19 & $<.034$ & .004 & $<8.5: 1$ \\
October 6 & $<.056$ & .037 & $<1.5: 1$ \\
\hline
\end{tabular}

Dissolved-solids concentrations in Lake Henry ranged from 598 to $704 \mathrm{mg} / \mathrm{L}$ and were smallest on June 29 and largest on May 1 and October 6 (table 16). As indicated by samples collected at site HEW2 near the lake surface and near the lake bottom and from specific-conductance measurements made at the other sites in Lake Henry, no substantial vertical or areal variations in dissolved-solids concentrations occurred on the sampling dates. Dissolved-solids concentrations (in $\mathrm{mg} / \mathrm{L}$ ) for Lake Henry can be approximated from specific-conductance measurements, as indicated from eight samples collected during the sampling period, by multiplying the specific conductance by 0.68 .

On the basis of the analysis of eight water samples collected at site HEW2, the predominant cation in Lake Henry is calcium and the predominant anion is sulfate. Calcium averaged about 47 percent of the cations, and sulfate averaged about 74 percent of the anions (as milliequivalents per liter).

The Colorado Department of Health has not established water-quality standards for the major chemical constituents for water use from Lake Henry. However, dissolved-solids concentration and the percentage of individual cations and anions are important factors in water used for agricultural purposes. Some investigators have recommended an upper limit of dissolved solids of about $5,000 \mathrm{mg} / \mathrm{L}$ for water to be used by livestock (Hem, 1985). Many crops are sensitive to large concentrations of dissolved solids. Dissolvedsolids concentrations from 500 to $1,000 \mathrm{mg} / \mathrm{L}$ can have detrimental effects on sensitive crops. Dissolvedsolids concentrations from 1,000 to $2,000 \mathrm{mg} / \mathrm{L}$ may have adverse effects on many crops (National Academy of Sciences, National Academy of Engineering, 1973).

Water that has a large proportion of sodium to total cations is not suitable as irrigation water. A large sodium content is toxic to some plants and causes the soil to become impermeable to water. The sodiumadsorption ratio of water is used to predict the degree to which sodium may replace adsorbed calcium and magnesium. The sodium-adsorption ratio is calculated using the following equation:

Sodium-adsorption ratio $=$

$$
\frac{\text { Sodium }}{\sqrt{1 / 2[\text { calcium+magnesium }]}}
$$

where sodium, calcium, and magnesium are expressed in milliequivalents per liter. Large sodium-adsorptionratio values imply a hazard of sodium replacing adsorbed calcium and magnesium, a situation that may damage the soil structure (Hem, 1985). The sodiumadsorption ratio for water samples analyzed in Lake Henry averaged about 1.4. Water that has a sodiumadsorption-ratio value less than 4 is safe for irrigating fruit; whereas, for most other crops, sodiumadsorption-ratio values that range from 8 to 18 are considered safe (National Academy of Sciences, National Academy of Engineering, 1973).

The Colorado Department of Health (1987) has established water-quality standards for selected trace elements for Lake Henry. On August 19 and October 6, concentrations of total-recoverable iron at site HEW2 exceeded the water-quality standard for aquatic life of $1,000 \mu \mathrm{g} / \mathrm{L}$. On August 19, totalrecoverable iron concentrations were $1,000 \mu \mathrm{g} / \mathrm{L}$ near the lake surface and $6,300 \mu \mathrm{g} / \mathrm{L}$ near the lake bottom; on October 6, concentrations of total-recoverable iron were $1,900 \mu \mathrm{g} / \mathrm{L}$ near the lake surface and $2,500 \mu \mathrm{g} / \mathrm{L}$ near the lake bottom. Concentrations of other trace elements were less than the water-quality standards or less than the detection limits for the analysis (table 16). 


\section{Biological Constituents}

The biological constituents analyzed in water samples collected from Lake Henry included phytoplankton and chlorophyll $a$. Phytoplankton populations are seldom homogeneous within a lake; therefore, the biological samples collected from Lake Henry may not be representative of the entire lake.

The groups of phytoplankton that occurred in Lake Henry during the sampling period were Bacillariophyta (diatoms), Chlorophyta (green algae), Chrysophyta (golden-brown algae), Cryptophyta (cryptomonads), Cyanophyta (blue-green algae), and Euglenophyta (euglenoids) (table 17, "Supplemental Data" section at the back of this report). The densities of phytoplankton collected near the lake surface at site HEW2 varied from 33,000 cells/mL on June 29 to 930,000 cells $/ \mathrm{mL}$ on August 19 (fig. 7). On each sampling date, blue-green algae comprised the greatest percentage of the phytoplankton density.

Of the total phytoplankton density on May 1, diatoms comprised about 0.4 percent; green algae comprised about 12 percent (Chlorella and Coccomyxa minor were the dominant algae); and cryptomonads comprised about 19 percent (Rhodomonas minuta was the only species detected). Cryptomonads are considered to be common winter algae (Wetzel, 1975), which might account for the larger concentration of this group analyzed on May 1. On May 1, blue-green algae comprised about 69 percent of the total phytoplankton density. Of this group, the most dominant genera were Aphanothece, Chroococcus, Microcystis, and Synechococcus.

The total phytoplankton density of 33,000 cells/mL on June 29 was less than analyzed on May 1 . According to Wetzel (1975), phytoplankton densities commonly increase in the spring and then decrease to a brief summer minimum. Of the total phytoplankton density on June 29 , diatoms comprised about 10 percent (Melosira granulata was the dominant species); green algae comprised about 11 percent (Coccomyxa minor was the dominant species); blue-green algae comprised about 79 percent; and cryptomonads and golden-brown algae comprised the remaining percentage.

A substantial increase in phytoplankton densities occurred between June 29 and August 19. On August 19, the total cell count was 930,000 cells $/ \mathrm{mL}$, and about 98 percent were blue-green algae. In more eutrophic lakes, the brief summer minimum often is followed by a late summer profusion of blue-green algae that lasts into autumn (Wetzel, 1975). Of the blue-green algae collected in August, about 91 percent were of the genus Microcystis. This algae commonly occurs in hard water and tends to develop in nutrientrich, eutrophic lakes during the warmest summer months (Hutchinson, 1967; Greeson, 1982). Various water-quality problems are associated with an abundant Microcystis population. This algae, where present in large masses, is capable of producing a foul odor and taste and may cause the death of fish in heavily infested lakes (Palmer, 1977; Greeson, 1982).

The phytoplankton population remained large on October 6 with a total density of 900,000 cells $/ \mathrm{mL}$. Blue-green algae comprised about 98 percent of the total phytoplankton density. The genus Microcystis was absent from this sample, and the genus Aphanothece was the dominant algae and comprised about 95 percent of the blue-green algae. Aphanothece is common to western lakes and is very small in size. This algae is not known to cause water-quality problems such as taste and odor and, as such, is not an indicator of water quality. Little is known about this algae because of its small size (Chadwick and Associates, oral commun., 1988). Decomposition of the large phytoplankton population present in October potentially could deplete dissolved oxygen.

During the sampling period, chlorophyll $a$ concentrations measured for site HEW2 at Lake Henry ranged from 1.6 to $26.1 \mu \mathrm{g} / \mathrm{L}$ and averaged about $10 \mu \mathrm{g} / \mathrm{L}$. The smallest concentrations were measured on May 1, and the largest concentrations were measured on October 6 (table 6). Concentrations of chlorophyll $a$ are used to determine trophic status.

Tabie 6. Concentrations of chlorophyll a for site HEW2 at Lake Henry

[ $\mu \mathrm{g} / \mathrm{L}$, micrograms per liter]

\begin{tabular}{ccc}
\hline $\begin{array}{c}\text { Sampiing } \\
\text { date, 1987 }\end{array}$ & $\begin{array}{c}\text { Samping depth } \\
\text { (feet) }\end{array}$ & $\begin{array}{c}\text { Chlorophyll } a \\
(\mu \mathrm{g} / \mathrm{L})\end{array}$ \\
\hline May 1 & 2.0 & 1.6 \\
& 8.0 & 4.2 \\
June 29 & 2.0 & 8.2 \\
& 8.0 & 7.1 \\
August 19 & 2.0 & 6.2 \\
& 4.0 & 8.0 \\
October 6 & 2.0 & 26.1 \\
& 5.0 & 19.0 \\
\hline
\end{tabular}


TOTAL CELL COUNT

MAY 1, 1987

52,000

CELLS PER MILLILITER

JUNE 291987

33,000

CELLS PER MILLILITER
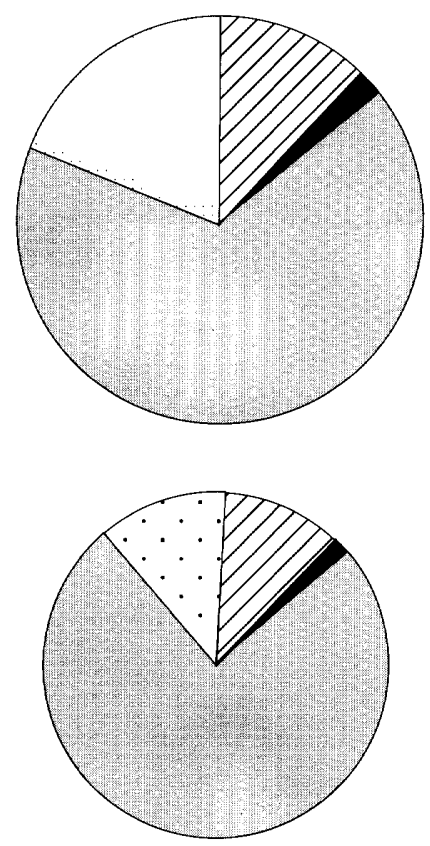

AUGUST 19, 1987

930,000

CELLS PER MILLILITER

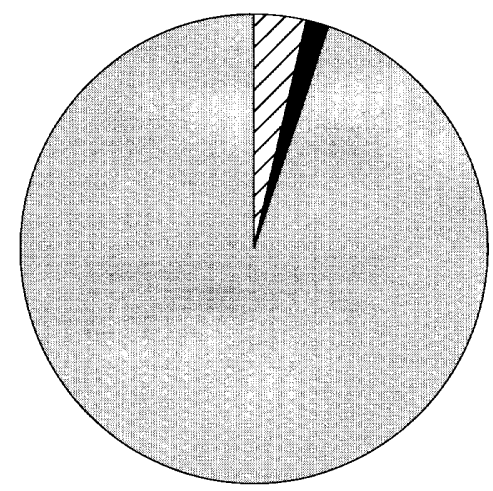

OCTOBER 6,1987

900,000

CELLS PER MILLILITER

\section{EXPLANATION}

TOTAL CELL-COUNT-Size of diagrams is proportional to the common logarithm of total cell counts. Phytoplankton groups with cell counts less than 1 percent of the total are included in OTHER category

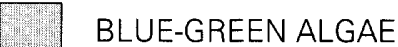

BLUE-GREENALGAE

CRYPTOMONADS

DIATOMS

GREEN ALGAE

OTHER

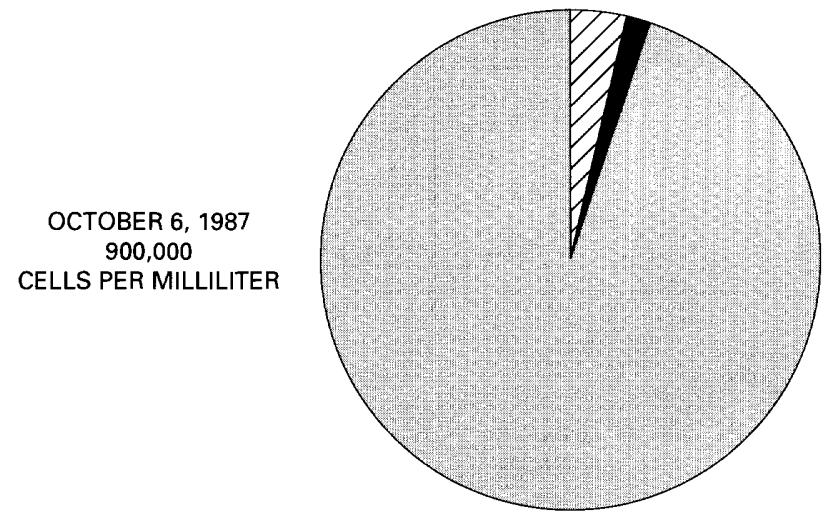

Figure 7. Densities and taxonomic composition of major phytoplankton groups collected from site HEW2 at Lake Henry on May 1, June 29, August 19, and October 6, 1987. 


\section{Trophic Status}

In calculating Carlson's trophic-state index (TSI) for Lake Henry, Secchi-disk depth (SD), average surface concentrations of total phosphorus (TP), and average surface concentrations of chlorophyll $a(\mathrm{Chl})$ were used from samples collected at site HEW2 on June 29 and August 19. The calculated TSI values for each trophic variable are:

$$
\begin{aligned}
& \text { TSI }(\mathrm{SD})=87 \\
& \text { TSI }(\mathrm{TP})=62 \\
& \text { TSI }(\mathrm{Chl})=50
\end{aligned}
$$

According to Carlson (1979), a TSI value of 41 is considered the upper limit for oligotrophy, and a TSI value of 51 is considered the lower limit for eutrophy. Based on the TSI values calculated using all three trophic variables, Lake Henry would be classified as eutrophic using Secchi-disk depth and total phosphorus and would be borderline eutrophic using chlorophyll $a$.

In applying the trophic variables to the fixedboundary system, data were used from samples collected at site HEW2 on May 1, June 29, August 19, and October 6 . The trophic classification for Lake Henry using this system uses mean annual values for the trophic variables and the minimum Secchi-disk measurement and the peak chlorophyll $a$ concentration. The boundary values for trophic categories and the values for the trophic variables for Lake Henry are listed in table 7. Because there were only four sampling dates during the sampling period, the trophic classification based on the mean annual values may be biased. However, the trophic classification for the minimum Secchi-depth measurement and peak chlorophyll $a$ concentration are the same as the trophic classification using the mean values. The resulting trophic classification using the fixed-boundary system agrees closely with the calculations for the trophic-state index. The trophic variables, where applied to the fixed-boundary system, indicate Lake Henry is hypereutrophic with respect to Secchi-disk depth and eutrophic with respect to total-phosphorus concentration and chlorophyll $a$ concentration.

Table 7. Comparison of fixed-boundary-system values to trophic-variable values for Lake Henry and Lake Meredith (modified

\begin{tabular}{|c|c|c|c|c|c|}
\hline \multirow[b]{2}{*}{ Trophic category } & \multicolumn{5}{|c|}{ Trophic variables } \\
\hline & $\begin{array}{c}\text { Minimum } \\
\text { Secchi-disk } \\
\text { depth } \\
\text { (feet) }\end{array}$ & $\begin{array}{c}\text { Mean } \\
\text { Secchi-disk } \\
\text { depth } \\
\text { (feet) }\end{array}$ & $\begin{array}{l}\text { Mean totai- } \\
\text { phosphorus } \\
\text { concentration } \\
\text { (miiligrams } \\
\text { per liter) }\end{array}$ & $\begin{array}{c}\text { Peak } \\
\text { chiorophyli a } \\
\text { concentration } \\
\text { (micrograms } \\
\text { per iiter) }\end{array}$ & $\begin{array}{c}\text { Mean } \\
\text { chiorophyil } a \\
\text { concentration } \\
\text { (micrograms } \\
\text { per ilter) }\end{array}$ \\
\hline Ultra-oligotrophic & $\geqq 19.7$ & $\geq 39.4$ & $\leqq 0.004$ & $\leqq 2.5$ & $\leqq 1.0$ \\
\hline Oligotrophic & $\geq 9.8$ & $\geq 19.7$ & $\leqq .010$ & $\leqq 8.0$ & $\leqq 2.5$ \\
\hline Mesotrophic & $9.8-4.9$ & $19.7-9.8$ & $.010-.035$ & $8.0-25$ & $2.5-8.0$ \\
\hline Eutrophic & $4.9-2.3$ & $9.8-4.9$ & $.035-.10$ & $25-75$ & $8.0-25$ \\
\hline Hypereutrophic & $\leqq 2.3$ & $\leq 4.9$ & $\geq .10$ & $\geq 75$ & $\geq 25$ \\
\hline Lake Henry (site HEW2) ${ }^{1}$ & .5 & .8 & .066 & 26.1 & 10.0 \\
\hline $\begin{array}{l}\text { Lake Meredith (sites M2B, } \\
\text { M1B, M4B) }\end{array}$ & .5 & .8 & .106 & 37.8 & 11.7 \\
\hline
\end{tabular}
from Organisation for Economic Co-operation and Development,1982)

$[\geqq$, greater than or equal to; $\leqq$, less than or equal to] 


\section{WATER-QUALITY CHARACTERISTICS OF LAKE MEREDITH AND COMPARISON TO WATER-QUALITY STANDARDS}

Water-quality characteristics of Lake Meredith were determined by onsite measurements made at 10 sites in the lake and by laboratory analysis for selected chemical and biological constituents in water samples collected at sites M2B, M1B, and M4B (fig. 3). Physical properties and results of analyses for chemical constituents were compared with waterquality standards established by the Colorado Department of Health.

\section{Onsite Measurements}

The water-temperature profiles shown in figure 8 are representative of the thermal characteristics that existed throughout Lake Meredith on the sampling dates. The temperatures in the lake ranged from $15.3^{\circ} \mathrm{C}$ at sites M2B and M1B near the lake bottom on May 1 to $27.9^{\circ} \mathrm{C}$ at site $\mathrm{M} 1 \mathrm{C}$ at the water surface on August 20 (table 18). Temperature measurements on May 1 indicate that the lake was thermally stratified because of spring warming of the upper water layer. The difference in the profile curves between site M2B and sites M1B and M4B on May 1 probably was due to mixing of the upper water layers from wave action caused by wind. On June 30, no thermal stratification occurred, and temperature was uniform vertically and areally throughout the lake. On August 20 and 21 and October 6, water temperatures decreased with depth.

The dissolved-oxygen and $\mathrm{pH}$ profiles shown in figure 9 exhibited similar changes with depth indicating dissolved-oxygen concentrations and $\mathrm{pH}$ are affected by photosynthesis and respiration.

Dissolved-oxygen concentrations in Lake Meredith ranged from $1.4 \mathrm{mg} / \mathrm{L}$ at site $\mathrm{M} 1 \mathrm{~A}$ at the lake bottom on August 20 to $10.3 \mathrm{mg} / \mathrm{L}$ at site M2B at a depth of $3 \mathrm{ft}$ on May 1. On May 1, Lake Meredith was thermally stratified, and a density barrier prevented transfer of dissolved oxygen from the surface waters to the lake bottom resulting in a stratification of dissolved oxygen. The increase in the dissolved-oxygen concentration from the lake surface to a depth of about $3 \mathrm{ft}$ at site M2B on May 1 probably was due to a concentration of phytoplankton at the top of the density barrier caused by thermal stratification. The larger dissolvedoxygen concentrations on May 1 probably were a result of photosynthesis and cooler water temperatures. On June 30 and August 20 and 21, warmer water temperatures contributed to algal blooms, which then caused a depletion of dissolved oxygen near the lake bottom because of decomposing algae. On October 6, dissolved-oxygen concentrations were larger than those on June 30 and August 20 and 21 because of cooler water temperatures.

A minimum allowable dissolved-oxygen concentration of $5.0 \mathrm{mg} / \mathrm{L}$ has been established for Lake Meredith for the maintenance of aquatic life and agriculture by the Colorado Department of Health (1987). Twenty measurements of dissolved-oxygen concentrations less than the $5.0 \mathrm{mg} / \mathrm{L}$ standard were made at lower depths. A summary of dissolved-oxygen measurements including those that were less than $5.0 \mathrm{mg} / \mathrm{L}$ are listed in table 8.

The $\mathrm{pH}$ of the water in Lake Meredith is affected by water that enters the lake from the Lake Meredith inlet and Bob Creek and by photosynthesis and respiration (table 9). The $\mathrm{pH}$ of the water in the lake ranged from 7.9 to 8.7 during the sampling period. Larger $\mathrm{pH}$ values occurred at the lake surface because of photosynthesis, and smaller pH occurred near the lake bottom where respiration predominates. The allowable range of $\mathrm{pH}$ established for Lake Meredith by the Colorado Department of Health (1987) for aquatic life is 6.5 to 9.0 , and the measured $\mathrm{pH}$ in the lake during the sampling period was within this range.

Profiles of specific conductance indicate there was minimal vertical and areal variation in measured values (fig. 10). Specific conductance measured during the sampling period ranged from $2,520 \mu \mathrm{S} / \mathrm{cm}$ on June 30 to $3,040 \mu \mathrm{S} / \mathrm{cm}$ on August 21. Between the June and August sampling dates, an increase in mean specific conductance of about 13 percent (from 2,560 to $2,950 \mu \mathrm{S} / \mathrm{cm}$ ) occurred in the lake. The temporal variations in specific conductance measured in Lake Meredith probably are the result of changes in the specific conductance of the inflows and an increase in the concentration of dissolved solids due to evaporation.

Light transparency in Lake Meredith probably is affected most by phytoplankton biomass; however, suspended sediments from the inflows and disturbed bottom sediments from wave action could decrease light transparency. Secchi-disk measurements varied areally and temporally in Lake Meredith. Secchi-disk depths generally were greater on May 1 than on the other sampling dates. The Secchi-disk depths were either 1.0 or $1.5 \mathrm{ft}$ on May 1 and either 0.5 or $1.0 \mathrm{ft}$ during the remainder of the sampling period (table 10). The areal variations in light transparency probably are due to a nonuniform distribution of phytoplankton within the lake. 


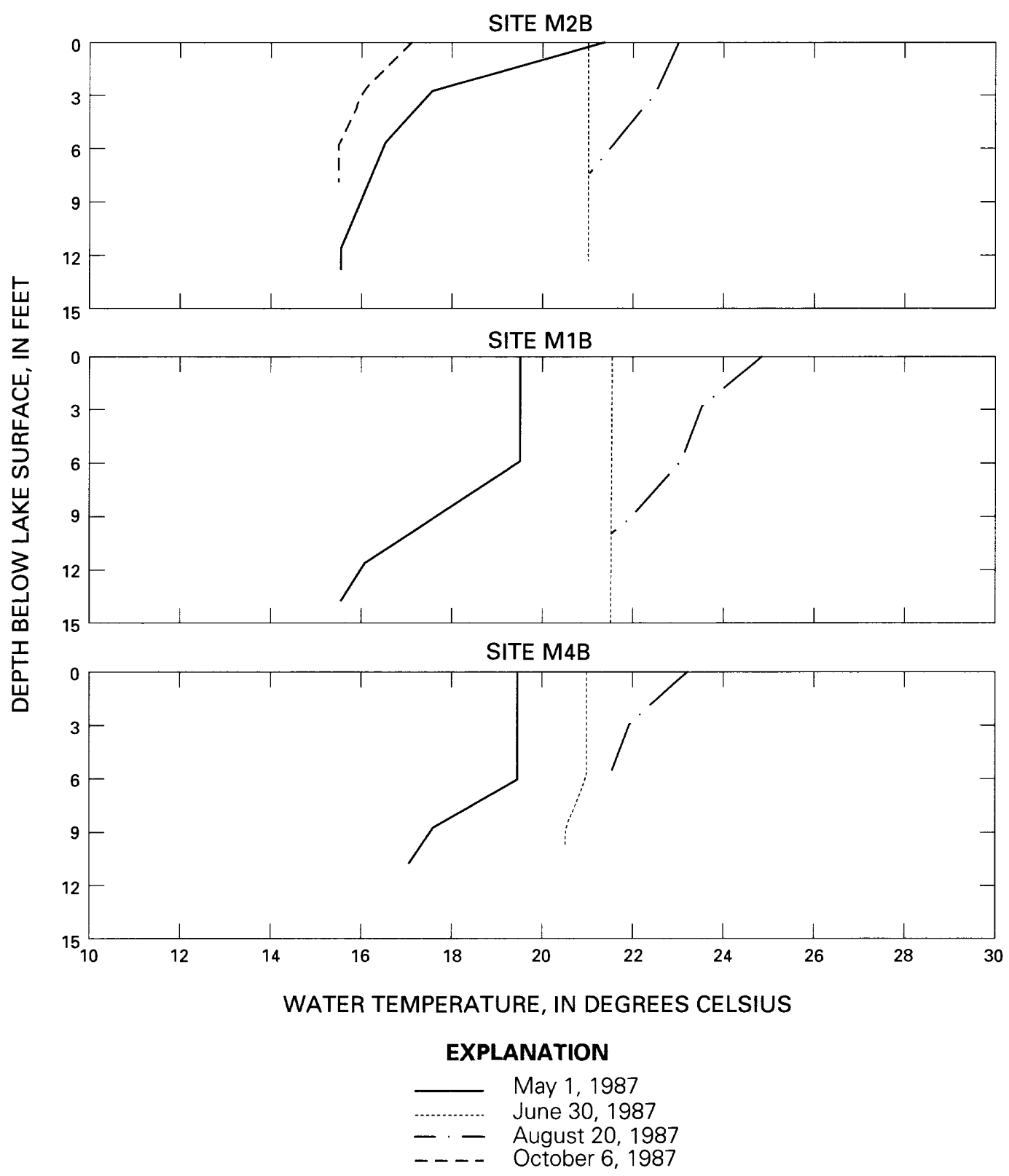

Figure 8. Profiles of water temperature at depth for sites M2B, M1B, and M4B at Lake Meredith. 


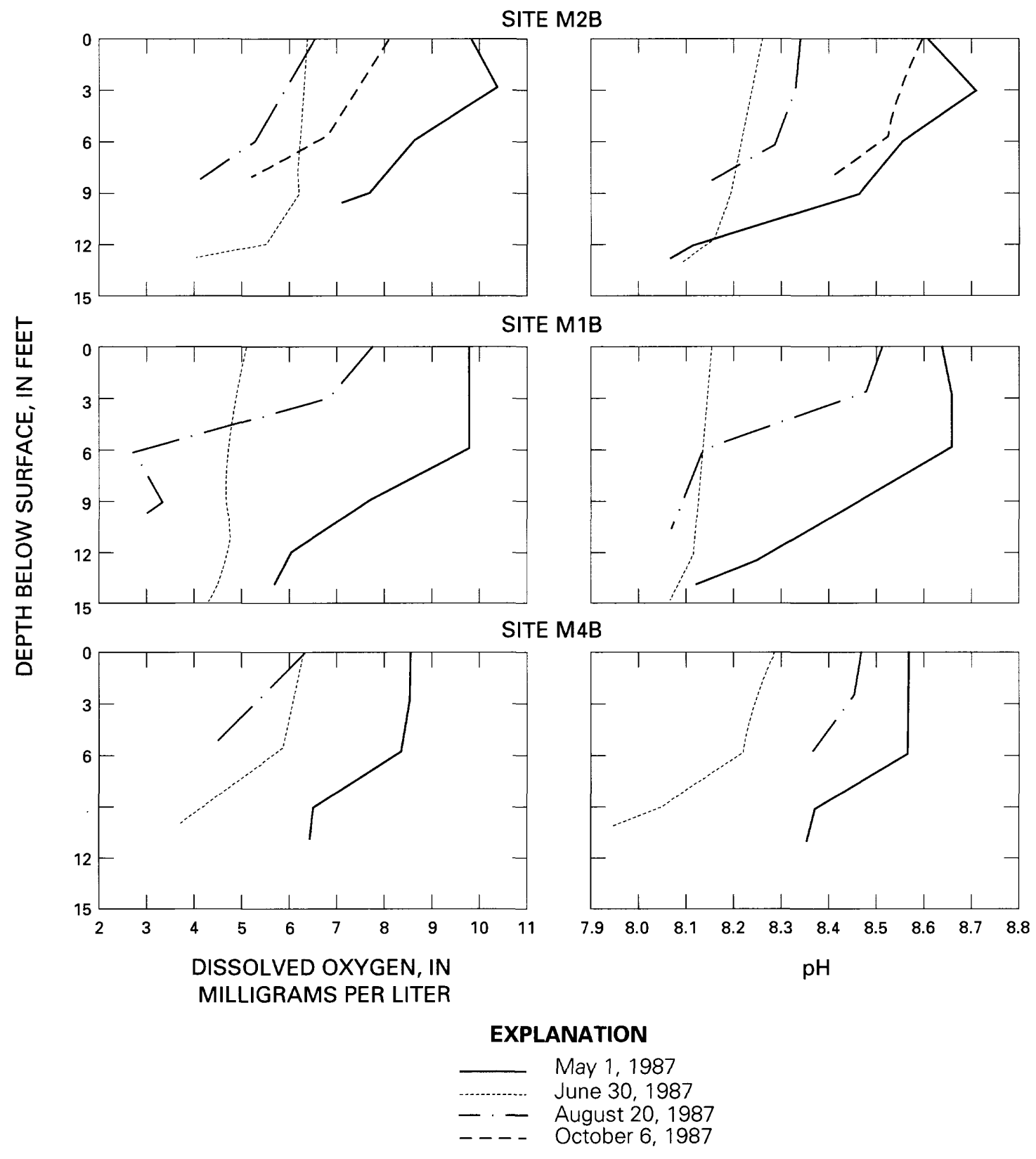

Figure 9. Profiles of dissolved oxygen and pH at depth for sites M2B, M1B, and M4B at Lake Meredith. 
Table 8. Summary of dissolved-oxygen measurements for all sites at Lake Meredith

[ft, feet; $\mathrm{mg} / \mathrm{L}$, milligrams per liter; <, less than; >, greater than]

\begin{tabular}{lccccc}
\hline $\begin{array}{c}\text { Sampling date, } \\
\mathbf{1 9 8 7}\end{array}$ & $\begin{array}{c}\text { Depth } \\
\mathbf{( f t )}\end{array}$ & $\begin{array}{c}\text { Number of } \\
\text { measurements }\end{array}$ & $\begin{array}{c}\text { Minimum } \\
\text { concentration } \\
(\mathbf{m g} / \mathbf{L})\end{array}$ & $\begin{array}{c}\text { Maximum } \\
\text { concentration } \\
(\mathbf{m g} / \mathbf{L})\end{array}$ & $\begin{array}{c}\text { Number of } \\
\text { measurements } \\
<5.0 \text { mg/L }\end{array}$ \\
\hline May 1 & $0-2$ & 3 & 8.6 & 9.9 & 0 \\
& $3-5$ & 3 & 8.6 & 10.3 & 0 \\
& $6-8$ & 3 & 8.4 & 9.9 & 0 \\
June 30 & $9-11$ & 4 & 6.4 & 7.9 & 0 \\
& $>11$ & 4 & 4.7 & 6.1 & 0 \\
& $0-2$ & 10 & 5.2 & 6.7 & 0 \\
& $3-5$ & 10 & 5.0 & 6.6 & 3 \\
August 20-21 & $6-8$ & 10 & 4.9 & 6.4 & 4 \\
& $9-11$ & 13 & 3.8 & 6.3 & 0 \\
& $>11$ & 9 & 4.4 & 6.2 & 0 \\
October 6 & $0-2$ & 11 & 6.0 & 9.1 & 6 \\
& $3-5$ & 9 & 5.5 & 9.4 & 4 \\
\hline
\end{tabular}

Table 9. Onsite measurements at the Lake Meredith inlet (MI1) and Bob Creek (MI2)

$\left[{ }^{\circ} \mathrm{C}\right.$, degrees Celsius; $\mathrm{mg} / \mathrm{L}$, milligrams per liter; $\mu \mathrm{S} / \mathrm{cm}$, microsiemens per centimeter at 25 degrees Celsius; dashes indicate no measurement]

\begin{tabular}{cccccc}
\hline $\begin{array}{c}\text { Sampling site } \\
\text { (fig. 3) }\end{array}$ & $\begin{array}{c}\text { Sampling date, } \\
\mathbf{1 9 8 7}\end{array}$ & $\begin{array}{c}\text { Water } \\
\text { temperature } \\
\left({ }^{\circ} \mathrm{C}\right)\end{array}$ & $\begin{array}{c}\text { Dissolved } \\
\text { oxygen } \\
(\mathbf{m g} / \mathrm{L})\end{array}$ & $\mathrm{pH}$ & $\begin{array}{c}\text { Specific } \\
\text { conductance } \\
(\mu \mathrm{S} / \mathrm{cm})\end{array}$ \\
\hline MI1 & $06-30$ & 20.2 & 7.5 & 8.3 & 513 \\
& $08-21$ & 23.7 & 7.1 & 8.1 & 3,500 \\
MI2 & $10-06$ & -- & -- & -- & - \\
& $06-30$ & 20.6 & 7.7 & 8.1 & 1,200 \\
& $08-20$ & 28.2 & 8.8 & 8.4 & 1,860 \\
& $10-06$ & 19.5 & 9.0 & 8.5 & 4,480 \\
\hline
\end{tabular}



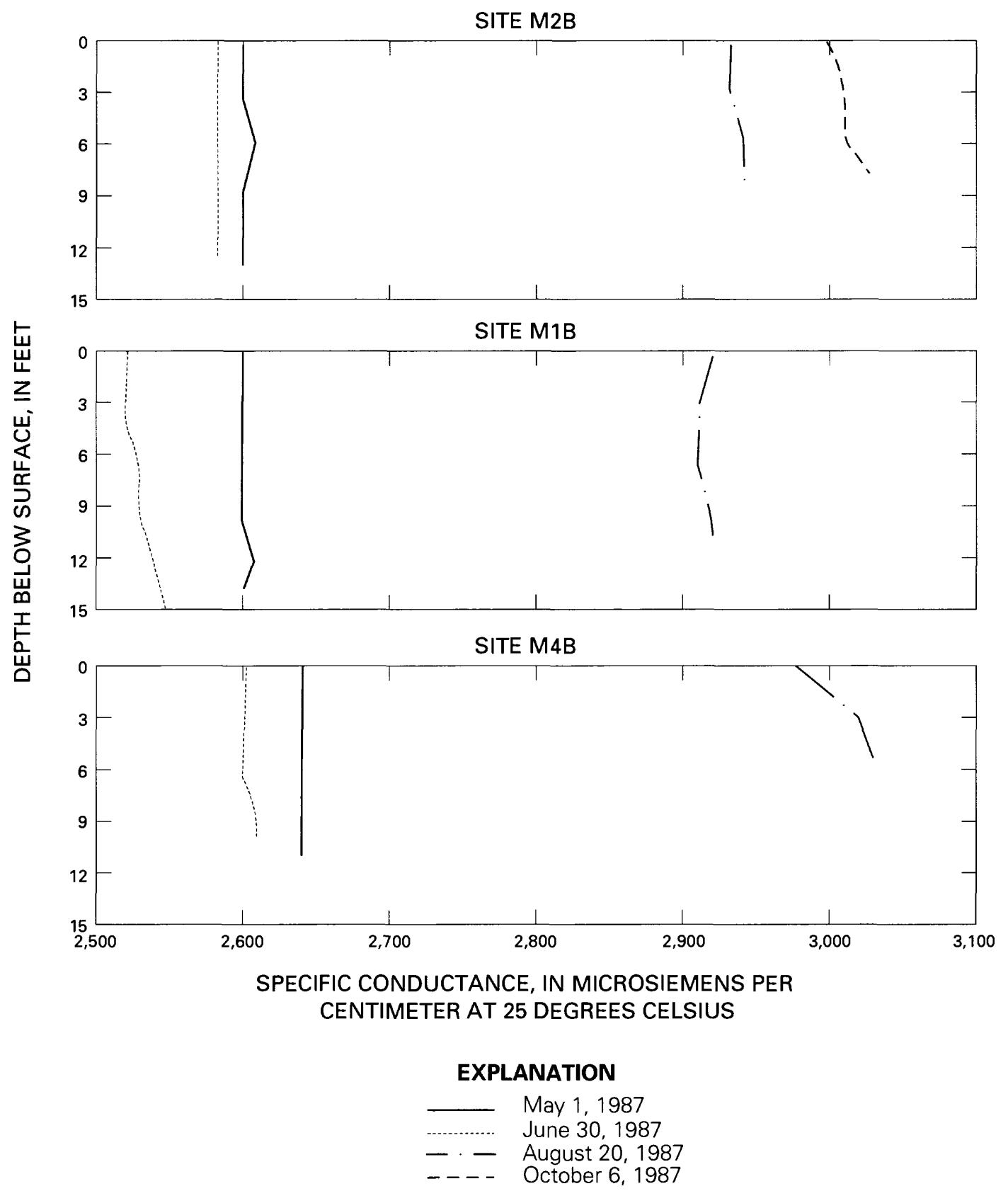

Figure 10. Profiles of specific conductance at depth for sites M2B, M1B, and M4B at Lake Meredith. 
Table 10. Light-transparency measurements for all sites at Lake Meredith

\begin{tabular}{ccc}
\hline $\begin{array}{c}\text { Samping site } \\
\text { (fig. 3) }\end{array}$ & $\begin{array}{c}\text { Sampling date, } \\
1987\end{array}$ & $\begin{array}{c}\text { Secchi- } \\
\text { disk depth' } \\
\text { (feet) }\end{array}$ \\
\hline M2B ${ }^{2}$ & $05-01$ & 1.5 \\
& $06-30$ & .5 \\
& $08-20$ & .5 \\
M1B & $10-06$ & .5 \\
& $05-01$ & 1.5 \\
M4B & $06-30$ & .5 \\
& $08-20$ & 1.0 \\
& $05-01$ & 1.0 \\
M1A & $06-30$ & .5 \\
& $08-21$ & .5 \\
M1C & $06-30$ & .5 \\
& $08-20$ & 1.0 \\
M2A & $06-30$ & .5 \\
& $08-20$ & 1.0 \\
M2C & $06-30$ & .5 \\
& $08-20$ & 1.0 \\
M3A & $06-30$ & .5 \\
& $08-20$ & 1.0 \\
M3B & $06-30$ & .5 \\
& $08-21$ & 1.0 \\
M4A & $06-30$ & .5 \\
& $08-21$ & 1.0 \\
& $06-30$ & .5 \\
\hline
\end{tabular}

'Light transparency represents the depth to the nearest 0.5 foot at which the Secchi disk was not visible.

${ }^{2} \mathrm{M} 2 \mathrm{~B}$ was the only site measured on October 6, 1987.

\section{Chemical Constituents}

During the sampling period, concentrations of total nitrogen at site $\mathrm{M} 2 \mathrm{~B}$ ranged from less than $1.3 \mathrm{mg} / \mathrm{L}$ to less than $2.0 \mathrm{mg} / \mathrm{L}$ and averaged less than about $1.6 \mathrm{mg} / \mathrm{L}$ (table 19). The principal nitrogen form was organic nitrogen, which averaged about 90 percent of the total nitrogen. The concentrations of totalinorganic nitrogen were less than $0.2 \mathrm{mg} / \mathrm{L}$ throughout the sampling period.

The Colorado Department of Health (1987) has established water-quality standards for aquatic life of $0.5 \mathrm{mg} / \mathrm{L}$ of total nitrite and $0.06 \mathrm{mg} / \mathrm{L}$ of un-ionized ammonia for Lake Meredith. Concentrations of total nitrite at sites M2B, M1B, and M4B ranged from 0.001 to $0.022 \mathrm{mg} / \mathrm{L}$ (tables $19-21$ ). Un-ionized ammonia is calculated as a percentage of total ammonia, given water temperature and $\mathrm{pH}$ (Willingham, 1976), and concentrations ranged from 0.003 to $0.031 \mathrm{mg} / \mathrm{L}$ at sites M2B, M1B, and M4B.

Concentrations of total phosphorus at sites M2B, $\mathrm{M} 1 \mathrm{~B}$, and M4B ranged from 0.062 to $0.148 \mathrm{mg} / \mathrm{L}$ and averaged $0.106 \mathrm{mg} / \mathrm{L}$. Orthophosphate as phosphorus (the biologically available form of phosphorus) averaged about 14 percent of the total phosphorus.

During the sampling period, concentrations of dissolved-inorganic nitrogen at site M2B were greater than $0.02 \mathrm{mg} / \mathrm{L}$ indicating nitrogen was not a limiting nutrient (Ryding, 1988). Concentrations of dissolved orthophosphate as phosphorus at site M2B were less than $0.010 \mathrm{mg} / \mathrm{L}$ on May 1 , June 30 , and August 20 indicating potential phosphorus limitation (Ryding, 1988). On October 6, the average dissolved orthophosphate as phosphorus concentration was $0.022 \mathrm{mg} / \mathrm{L}$ indicating phosphorus was not a limiting nutrient.

The mass ratio of dissolved-inorganic nitrogen to dissolved orthophosphate as phosphorus was greater than 7:1 on the May, June, and August sampling dates (table 11) indicating potential phosphorus limitation (Ryding, 1988). On the October sampling date, the mass ratio of dissolved-inorganic nitrogen to dissolved orthophosphate as phosphorus was less than 7:1 indicating potential nitrogen limitation (Ryding, 1988).

Dissolved-solids concentrations at site M2B ranged from 1,870 to $2,370 \mathrm{mg} / \mathrm{L}$ and were smallest on June 30 and largest on October 6 (table 19). As indicated by samples collected at site M2B near the lake surface and near the lake bottom and from specificconductance measurements made at the other sites in Lake Meredith, no substantial vertical or areal variations in dissolved solids occurred on the sampling dates. Dissolved-solids concentrations (in $\mathrm{mg} / \mathrm{L}$ ) in Lake Meredith can be approximated from specificconductance measurements, as indicated from eight samples collected at site M2B during the sampling period, by multiplying the specific-conductance measurement by 0.76 .

Based on analysis of eight water samples collected at site M2B, the predominant cation in Lake Meredith is sodium and the predominant anion is sulfate. Sodium averaged about 47 percent of the cations, and sulfate averaged about 83 percent of the anions (as milliequivalents per liter).

The Colorado Department of Health has not established water-quality standards for the major chemical constituents for water use from Lake Meredith. However, dissolved-solids concentrations and the percentage of individual cations and anions are important factors in water used for agricultural purposes as discussed for Lake Henry. 
Table 11. Average concentrations of dissolved-inorganic nitrogen and dissolved orthophosphate as phosphorus and corresponding ratios for site M2B at Lake Meredith

[mg/L, milligrams per liter; <, less than]

\begin{tabular}{rcrr}
\hline $\begin{array}{c}\text { Samping date, } \\
1987\end{array}$ & $\begin{array}{c}\text { Dissoived-inorganic } \\
\text { nitrogen } \\
(\mathbf{m g} / \mathrm{L})\end{array}$ & $\begin{array}{c}\text { Dissoived } \\
\text { orthophosphate } \\
\text { as phosphorus } \\
\text { (mg/L) }\end{array}$ & $\begin{array}{c}\text { Ratio of dissoived- } \\
\text { inorganic nitrogen to } \\
\text { dissoived orthophosphate } \\
\text { as phosphorus }\end{array}$ \\
\hline May 1 & $<0.165$ & $<0.001$ & $<165: 1$ \\
June 30 & $<.110$ & .004 & $<27.5: 1$ \\
August 20 & .108 & .006 & $18: 1$ \\
October 6 & .122 & .022 & $5.5: 1$ \\
\hline
\end{tabular}

The sodium-adsorption ratio for water samples analyzed in Lake Meredith averaged about 5. Water that has a sodium-adsorption-ratio value less than 4 is safe for irrigating fruit; whereas, for most other crops, sodium-adsorption-ratio values that range from 8 to 18 are considered safe (National Academy of Sciences, National Academy of Engineering, 1973).

The Colorado Department of Health (1987) has established water-quality standards for selected trace elements in Lake Meredith. Concentrations of totalrecoverable iron at sites M1B and M4B exceeded the standard for aquatic life of $1,000 \mu \mathrm{g} / \mathrm{L}$, and concentrations of total-recoverable boron occasionally exceeded the standard of $750 \mu \mathrm{g} / \mathrm{L}$ at site M2B. Data in table 12 list the concentrations of total-recoverable iron and total recoverable boron that exceeded the water-quality standards established by the Colorado Department of Health (1987). Concentrations of other trace elements were less than the water-quality standards or less than the detection limit for the analysis (tables 19-21).

Table 12. Concentrations of total-recoverable iron and total-recoverable boron that exceeded the water-quality standards established for Lake Meredith by the Colorado Department of Health (1987)

$[\mu \mathrm{g} / \mathrm{L}$, micrograms per liter; --, concentrations did not exceed the water-quality standard]

\begin{tabular}{|c|c|c|c|c|}
\hline $\begin{array}{l}\text { Sampling site } \\
\text { (fig. 3) }\end{array}$ & $\begin{array}{c}\text { Sampiing date, } \\
1987\end{array}$ & $\begin{array}{l}\text { Depth } \\
\text { (feet) }\end{array}$ & $\begin{array}{c}\text { Total-recoverabie } \\
\text { iron } \\
(\mu g / L)\end{array}$ & $\begin{array}{c}\text { Totai-recoverabie } \\
\text { boron } \\
(\mu g / L)\end{array}$ \\
\hline M2B & $08-20$ & 2 & -- & 770 \\
\hline M2B & $08-20$ & 6 & -- & 770 \\
\hline M2B & $10-06$ & 2 & -- & 810 \\
\hline M2B & $10-06$ & 7 & -- & 810 \\
\hline M1B & $06-30$ & 12 & 1,300 & -- \\
\hline M4B & $06-30$ & 2 & 1,300 & -- \\
\hline M4B & $06-30$ & 8 & 1,800 & -- \\
\hline M4B & $08-21$ & 2 & 1,500 & -- \\
\hline M4B & $08-21$ & 4 & 1,500 & -. \\
\hline & Standard & & 1,000 & 750 \\
\hline
\end{tabular}




\section{Biological Constituents}

The biological constituents analyzed in water samples collected from Lake Meredith included phytoplankton and chlorophyll $a$. Phytoplankton populations are seldom homogeneous within a lake; therefore, the biological samples collected from Lake Meredith may not be representative of the entire lake.

The groups of phytoplankton that occurred in Lake Meredith during the sampling period were Bacillariophyta (diatoms), Chlorophyta (green algae), Chrysophyta (golden-brown algae), Cryptophyta (cryptomonads), Cyanophyta (blue-green algae), Euglenophyta (euglenoids), and Pyrrhophyta (dinoflagellates) (table 22, "Supplemental Data" section at the back of this report). The densities of phytoplankton collected near the surface at site M2B ranged from 58,000 cells $/ \mathrm{mL}$ on May 1 to 3,900,000 cells $/ \mathrm{mL}$ on October 6 (fig. 11). On each sampling date, bluegreen algae comprised the largest percentage of the phytoplankton density.

Of the total phytoplankton density on May 1, diatoms comprised about 7.5 percent, and Cyclotella stelligera comprised about 94 percent of this group; green algae comprised about 24 percent; and blue-green algae comprised about 65 percent, and Aphanothece and Aphanocapsa comprised about 75 percent of this group. The remainder of the total phytoplankton density consisted of golden-brown algae, euglenoids, dinoflagellates, and cryptomonads.

The phytoplankton density on June 30 increased to $2,100,000$ cells $/ \mathrm{mL}$ of which about 99 percent were blue-green algae. Microcystis incerta comprised about 87 percent of the blue-green algae. This species is common in hard water and tends to develop in nutrientrich, eutrophic lakes during the warmest summer months (Hutchinson, 1967; Greeson, 1982). Various water-quality problems are associated with an abundant Microcystis population. This algae, where present in large masses, is capable of producing a foul odor and taste and may cause the death of fish in heavily infested lakes (Palmer, 1977; Greeson, 1982). The remainder of the phytoplankton consisted of diatoms, green algae, and euglenoids.

On August 20, the phytoplankton density was $2,400,000$ cells $/ \mathrm{mL}$. Green algae comprised about 2.5 percent of the total, and blue-green algae comprised more than 96 percent of the total. The remainder of the phytoplankton were diatoms, euglenoids, and cryptomonads.

The largest phytoplankton density of 3,900,000 cells $/ \mathrm{mL}$ was analyzed for October 6 . Green algae comprised about 1.3 percent of the total, and bluegreen algae comprised more than 98 percent of the total. The remainder of the phytoplankton population consisted of diatoms, euglenoids, and cryptomonads.
During the sampling period, concentrations of chlorophyll $a$ measured in Lake Meredith ranged from 0 to $37.8 \mu \mathrm{g} / \mathrm{L}$ and averaged about $11.7 \mu \mathrm{g} / \mathrm{L}$. The smallest concentrations were measured on May 1 , and the largest concentrations were measured on October 6 (table 13).

Table 13. Concentrations of chlorophyll a for sites M2B, $M 1 B$, and M4B at Lake Meredith

$[\mu \mathrm{g} / \mathrm{L}$, micrograms per liter]

\begin{tabular}{clrc}
\hline $\begin{array}{c}\text { Sampiing } \\
\text { site } \\
\text { (fig. 3) }\end{array}$ & $\begin{array}{c}\text { Sampling } \\
\text { date, } \\
\mathbf{1 9 8 7}\end{array}$ & $\begin{array}{c}\text { Samping } \\
\text { depth } \\
\text { (feet) }\end{array}$ & $\begin{array}{c}\text { Chiorophyii a } \\
(\mu \mathrm{g} / \text { ) }\end{array}$ \\
\hline M2B & May 1 & 2 & 4.0 \\
& & 10 & 20.6 \\
& June 30 & 2 & 7.4 \\
& August 20 & 11 & 8.0 \\
& & 6 & 7.3 \\
& October 6 & 2 & 7.5 \\
& & 7 & 37.8 \\
M1B & May 1 & 2 & 2.6 \\
& June 30 & 2 & 5.5 \\
& & 12 & 7.6 \\
& August 20 & 2 & 16.9 \\
& & 8 & 6.2 \\
M4B & May 1 & 2 & 0.0 \\
& June 30 & 2 & 8.3 \\
& & 8 & 8.8 \\
& August 21 & 2 & 21.0 \\
& & 4 & 23.0 \\
\hline
\end{tabular}

\section{Trophic Status}

In calculating Carlson's trophic-state index (TSI) for Lake Meredith, Secchi-disk depth (SD), average surface concentrations of total phosphorus (TP), and average surface concentrations of chlorophyll $a(\mathrm{Chl})$ were used from samples collected at sites M2B, M1B, and M4B on June 30 and August 20 and 21. The average TSI values were greater than 51 for each trophic variable (table 14), which is considered by Carlson (1979) to be eutrophic.

In applying the trophic variables to the fixedboundary system, data were used from samples collected at sites M2B, M1B, and M4B on May 1, June 30, and August 20-21, and at site M2B on October 6 (table 7). The resulting trophic classification agrees closely with the calculations for the trophic-state index. The trophic classification, using the fixed-boundary system, indicates 
TOTAL CELL COUNT

MAY 1, 1987 58,000

CELLS PER MILLILITER

JUNE 30, 1987 $2,100,000$

CELLS PER MILLILITER
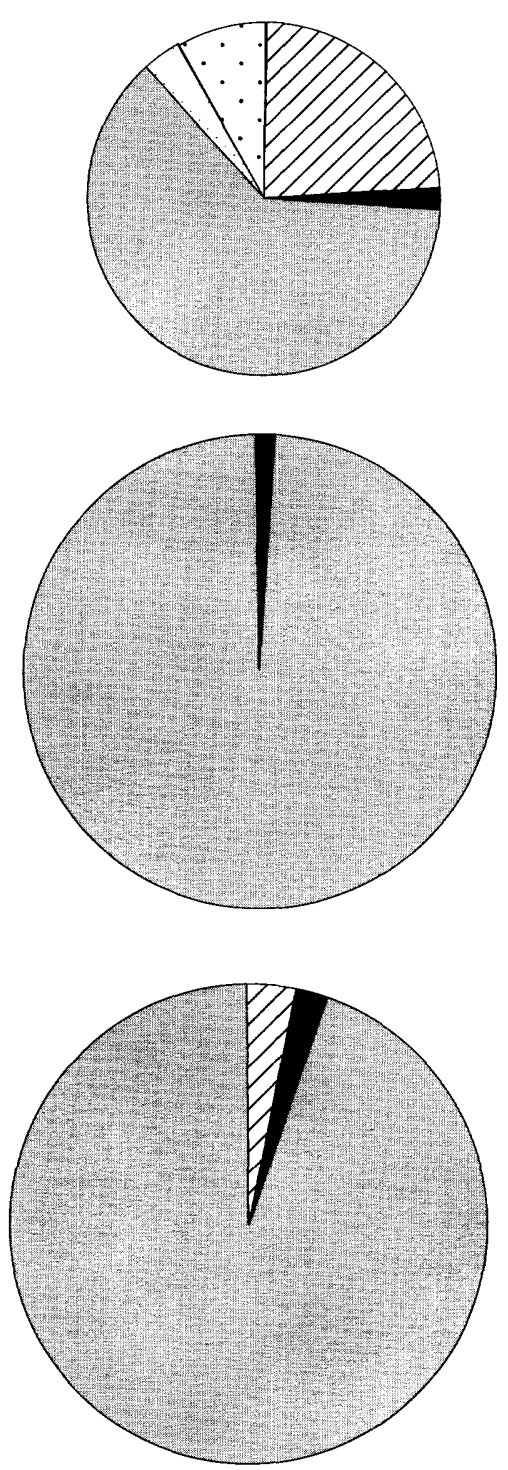

2,400,000
AUGT 20, 1987

CELLS PER MILLILITER
OCTOBER 6,1987

$3,900,000$

CELLS PER MILLILITER

\section{EXPLANATION}

TOTAL CELL-COUNT-Size of diagrams is proportional to the common logarithm of total cell counts. Phytoplankton groups with cell counts less than 1 percent of the total are included in OTHER category

\section{BLUE-GREEN ALGAE}

CRYPTOMONADS

$\therefore$ DIATOMS

VA

GREEN ALGAE

OTHER

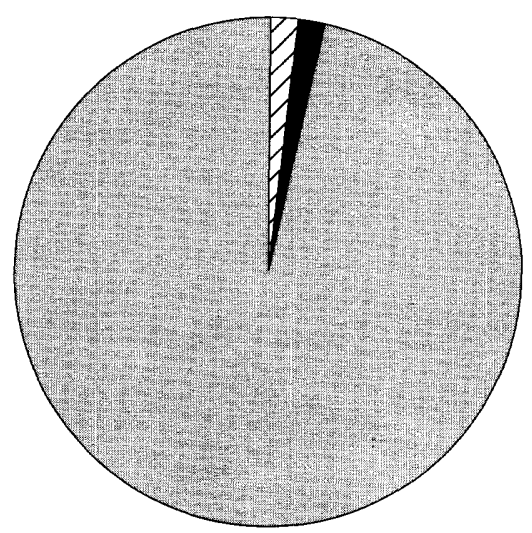

Figure 11. Densities and taxonomic composition of major phytoplankton groups collected from site M2B at Lake Meredith on May 1, June 30, August 20, and October 6, 1987. 
Table 14. Trophic-state indices for sites M2B, M1B, and M4B at Lake Meredith

[TSI, trophic-state index; SD, Secchi-disk depth; TP, total phosphorus; Chl, chlorophyll $a$ ]

\begin{tabular}{lccc}
\hline $\begin{array}{c}\text { Sampling site } \\
\text { (fig. 3) }\end{array}$ & $\begin{array}{c}\text { TSI } \\
\text { (SD) }\end{array}$ & $\begin{array}{c}\text { TSI } \\
\text { (TP) }\end{array}$ & $\begin{array}{c}\text { TSI } \\
\text { (Chl) }\end{array}$ \\
\hline M2B & 87 & 70 & 50 \\
M1B & 82 & 72 & 52 \\
M4B & 87 & 76 & 56 \\
Average (all sites) & 85 & 73 & 53 \\
\hline
\end{tabular}

Lake Meredith is hypereutrophic with respect to Secchidisk depth and total-phosphorus concentration and eutrophic with respect to chlorophyll $a$ concentration.

\section{COMPARISON OF SELECTED WATER- QUALITY CHARACTERISTICS BETWEEN LAKE HENRY AND LAKE MEREDITH}

Water released from Lake Henry can be diverted into one of the inflows to Lake Meredith (fig. 1); therefore, the water quality of Lake Henry may have an effect on the water quality of Lake Meredith.

During the sampling period, the thermal properties of Lake Henry and Lake Meredith were similar. Both lakes were thermally stratified on the May sampling date and not stratified on the June sampling date, and temperature profiles of both lakes were similar on the August and October sampling dates. Dissolved-oxygen concentrations and $\mathrm{pH}$ values in Lake Henry and in Lake Meredith were larger near the lake surface and were smaller near the lake bottom because of the effect of photosynthesis and respiration by phytoplankton. Average specific conductance in Lake Henry was about one-third the average specific conductance in Lake Meredith indicating that Lake Henry had smaller dissolved-solids concentrations than did Lake Meredith.

Nitrogen and phosphorus concentrations varied between Lake Henry and Lake Meredith. Concentrations of total nitrogen averaged about $1.1 \mathrm{mg} / \mathrm{L}$ in Lake Henry and less than about $1.6 \mathrm{mg} / \mathrm{L}$ in Lake Meredith. Concentrations of total phosphorus averaged about $0.066 \mathrm{mg} / \mathrm{L}$ in Lake Henry and about $0.106 \mathrm{mg} / \mathrm{L}$ in Lake Meredith. The ratios of dissolved-inorganic nitrogen to dissolved orthophosphate as phosphorus for Lake Henry and Lake Meredith indicate that phosphorus has the potential of being the limiting plant nutrient in both lakes. However, the large algal biomass sampled in each lake indicates neither nitrogen nor phosphorus are limiting nutrients. The predominant chemical constituents were calcium and sulfate in Lake Henry and sodium and sulfate in Lake Meredith. The water in both lakes had a small sodium-adsorption ratio. However, the sodium-adsorption ratio values for Lake Meredith (average about 5) were substantially larger than for Lake Henry (average about 1.4). Concentrations of total-recoverable iron in Lake Henry and totalrecoverable iron and total-recoverable boron in Lake Meredith were the only chemical constituents that occasionally exceeded the water-quality standards established by the Colorado Department of Health (1987). The larger concentrations of totalrecoverable iron and total-recoverable boron may have been caused by reducing conditions in the lower depths of the lakes under depleted dissolvedoxygen concentrations or concentration by evaporation.

The average phytoplankton densities in Lake Henry were about 38 percent of the average phytoplankton densities in Lake Meredith. During the sampling period, blue-green algae comprised the largest percentage of the phytoplankton densities in both lakes. The trophic status of both lakes would be considered eutrophic using trophic-classification systems developed by Carlson (1977) and the Organisation for Economic Co-operation and Development (1982); however, Lake Meredith could be considered more eutrophic than Lake Henry.

\section{SUMMARY}

Lake Henry and Lake Meredith are shallow, off-stream storage reservoirs for the Colorado Canal. Water stored in each lake primarily is used for agricultural purposes. The Colorado Department of Health has established water-quality standards pertaining to the uses of both lakes.

Lake Henry and Lake Meredith were sampled four times during 1987 for the purposes of: (1) Evaluating selected water-quality characteristics of each lake; (2) comparing the current water quality of Lake Henry and Lake Meredith to waterquality standards established by the Colorado Department of Health (1987); (3) describing the trophic status of each lake; and (4) comparing the water-quality between the two lakes.

During the study period, water temperature in Lake Henry ranged from 14.2 to $26.4^{\circ} \mathrm{C}$. The lake was thermally stratified on May 1 and not stratified on June 29 . Concentrations of dissolved oxygen ranged from 4.7 to $7.8 \mathrm{mg} / \mathrm{L}$; the $\mathrm{pH}$ 
ranged from 8.1 to 8.6 during the sampling period. Dissolved-oxygen concentrations and $\mathrm{pH}$ were largest near the lake surface as a result of photosynthesis and smallest near the lake bottom, where respiration occurs. Specific conductance in Lake Henry ranged from $889 \mu \mathrm{S} / \mathrm{cm}$ on June 29 to $1,010 \mu \mathrm{S} / \mathrm{cm}$ on October 6 but did not vary vertically and areally in the lake. Secchi-disk measurements indicated uniform light transparency throughout the lake. On May 1, Secchi-disk depths were $1.5 \mathrm{ft}$, and during the remainder of the study period Secchi-disk depths were $0.5 \mathrm{ft}$. Light transparency in Lake Henry is affected by phytoplankton biomass and nonalgal suspended material.

Total-nitrogen concentrations ranged from 0.86 to $1.4 \mathrm{mg} / \mathrm{L}$, and total-phosphorus concentrations ranged from 0.030 to $0.106 \mathrm{mg} / \mathrm{L}$ during the sampling period. Dissolved-solids concentrations ranged from 598 to $704 \mathrm{mg} / \mathrm{L}$, and calcium and sulfate comprised the largest percentage of the major chemical constituents. At site HEW2, concentrations of totalrecoverable iron occasionally exceeded the Colorado Department of Health water-quality standard of $1,000 \mu \mathrm{g} / \mathrm{L}$. On August 19, total-recoverable iron concentrations were $1,000 \mu \mathrm{g} / \mathrm{L}$ near the lake surface and $6,300 \mu \mathrm{g} / \mathrm{L}$ near the lake bottom; on October 6 , concentrations of total-recoverable iron were $1,900 \mu \mathrm{g} / \mathrm{L}$ near the lake surface and $2,500 \mu \mathrm{g} / \mathrm{L}$ near the lake bottom. Concentrations of other trace elements were less than the water-quality standards or less than the detection limits for the analysis.

The groups of phytoplankton sampled in Lake Henry during the sampling period were diatoms, green algae, golden-brown algae, cryptomonads, blue-green algae, and euglenoids. The concentrations of phytoplankton collected at site HEW2 ranged from 33,000 cells/mL on June 29 to 930,000 cells/mL on August 19. On each sampling date, blue-green algae accounted for the greatest percentage of the phytoplankton density. The trophic status of Lake Henry is eutrophic as indicated by the trophic-state index and the fixed-boundary system.

During the sampling period, water temperatures in Lake Meredith ranged from 15.3 to $27.9^{\circ} \mathrm{C}$. The lake was thermally stratified on May 1 and was not stratified on June 30. Concentrations of dissolved oxygen ranged from 1.4 to $10.3 \mathrm{mg} / \mathrm{L}$. Concentrations of dissolved oxygen less than the $5.0 \mathrm{mg} / \mathrm{L}$ water-quality standard were measured near the lake bottom on May 1, June 30, and August 20 and 21. The $\mathrm{pH}$ of the water in Lake Meredith ranged from 7.9 to 8.7. Dissolved-oxygen concentrations and $\mathrm{pH}$ in Lake Meredith were largest near the lake surface as a result of photosynthesis and smallest near the lake bottom where respiration occurs. Specific conductance in the lake ranged from $2,520 \mu \mathrm{S} / \mathrm{cm}$ on June 30 to $3,040 \mu \mathrm{S} /$ $\mathrm{cm}$ on August 21 but did not vary vertically and areally. Secchi-disk measurements ranged from 0.5 to $1.5 \mathrm{ft}$ and were largest on May 1. Light transparency in Lake Meredith is affected by phytoplankton biomass and nonalgal suspended material.

Concentrations of total nitrogen at site M2B ranged from less than $1.3 \mathrm{mg} / \mathrm{L}$ to less than $2.0 \mathrm{mg} / \mathrm{L}$ during the sampling period. At sites $\mathrm{M} 2 \mathrm{~B}, \mathrm{M} 1 \mathrm{~B}$, and $\mathrm{M} 4 \mathrm{~B}$, concentrations of total phosphorus ranged from 0.062 to $0.148 \mathrm{mg} / \mathrm{L}$. Dissolved-solids concentrations at site $\mathrm{M} 2 \mathrm{~B}$ ranged from 1,870 to $2,370 \mathrm{mg} / \mathrm{L}$, and sodium and sulfate comprised the largest percentage of the major chemical constituents. At sites M1B and M4B on June 30 and August 21, concentrations of total-recoverable iron ranged from 1,300 to $1,800 \mu \mathrm{g} / \mathrm{L}$, which exceeded the $1,000 \mu \mathrm{g} / \mathrm{L}$ Colorado Department of Health water-quality standard. Concentrations of total-recoverable boron at site M2B on August 20 and October 6 ranged from 770 to $810 \mu \mathrm{g} / \mathrm{L}$, which exceeded the $750 \mu \mathrm{g} / \mathrm{L}$ water-quality standard. Concentrations of other trace elements were less than the water-quality standards or less than the detection limits for the analysis.

The groups of phytoplankton sampled at site M2B during the sampling period were diatoms, green algae, golden-brown algae, cryptomonads, blue-green algae, euglenoids, and dinoflagellates. The concentrations of phytoplankton collected at site $\mathrm{M} 2 \mathrm{~B}$ ranged from 58,000 cells $/ \mathrm{mL}$ on May 1 to $3,900,000$ cells $/ \mathrm{mL}$ on October 6. On each sampling date, blue-green algae comprised the largest percentage of the phytoplankton density. The trophic status of Lake Meredith as determined using the trophic-state index and the fixedboundary system indicates Lake Meredith is a eutrophic lake.

During the sampling period, the thermal properties of Lake Henry and Lake Meredith were similar. Dissolved-oxygen concentrations and $\mathrm{pH}$ values in Lake Henry and in Lake Meredith were larger near the lake surface and smaller near the lake bottom because of the effect of photosynthesis and respiration by phytoplankton. Average specific conductance in Lake Henry was about one-third the average specific conductance in Lake Meredith.

Nutrient concentrations varied between Lake Henry and Lake Meredith. Nutrient concentrations were generally smaller in Lake Henry than in Lake Meredith. The predominant chemical constituents were calcium and sulfate in Lake Henry and sodium and sulfate in Lake Meredith. Concentrations of totalrecoverable iron in Lake Henry and total-recoverable iron and total-recoverable boron in Lake Meredith 
were the only chemical constituents that occasionally exceeded the water-quality standards established by the Colorado Department of Health (1987).

The average phytoplankton densities in Lake Henry were about 38 percent of the average phytoplankton densities in Lake Meredith. Blue-green algae comprised the largest percentage of the phytoplankton densities in both lakes. The trophic status of both lakes is eutrophic; however, Lake Meredith could be considered more eutrophic than Lake Henry.

\section{SELECTED REFERENCES}

Abbott, P. O., 1985, Description of water-systems operations in the Arkansas River basin, Colorado: U.S. Geological Survey Water-Resources Investigations Report 85-4092, 67 p.

Britton, L. J., Averett, R.C., and Ferreira, R.F., 1975, An introduction to the processes, problems, and management of urban lakes: U.S. Geological Survey Circular 601-K, $22 \mathrm{p}$.

Britton, L. J., and Greeson, P.E., 1989, Methods for collection and analyses of aquatic biological and microbiological samples: U.S. Geological Survey Techniques of Water-Resources Investigations, bk. 5, chap. A4, 363 p.

Britton, L. J., and Wentz, D.A., 1980, Water-quality characteristics of selected lakes and reservoirs in Colorado: U.S. Geological Survey Water-Resources Investigations Open-File Report 80-436, 139 p.

Brown, Eugene, Skougstad, M.W., and Fishman, M.J., 1970, Methods for collection and analysis of water samples for dissolved minerals and gases: U.S. Geological Survey Techniques of Water-Resources Investigations, bk. 5, chap. A1, 160 p.

Cain, Doug, 1985, Quality of the Arkansas River and irrigation-return flows in the lower Arkansas River Valley, Colorado: U.S. Geological Survey Water-Resources Investigations Report 84-4273, 85 p.

Carlson, R.E., 1977, A trophic state index for lakes: Limnology and Oceanography, v. 22, no. 2, p. 361-369. 1979, A review of the philosophy and construction of trophic state indices, in Maloney, T.E., ed., Lake and reservoir classification systems: Corvallis, Oreg., U.S. Environmental Protection Agency, EPA-600/3-79-074, p. 1-52.

Colorado Department of Health, 1987, Classifications and numeric standards, Arkansas River basin: Denver, Colorado Department of Health, Water Quality Control Commission, $72 \mathrm{p}$.

Dillon, P.J., and Rigler, F.H., 1974, The phosphoruschlorophyll relationship in lakes: Limnology and Oceanography, v. 19, no. 5, p. 767-773.

Fishman, M. J., and Friedman, L.C., eds., 1985, Methods for determination of inorganic substances in water and flu- vial sediments: U.S. Geological Survey Open-File Report 85-495, 709 p.

Goldman, C.R., and Horne, A.J., 1983, Limnology: New York, McGraw-Hill, 464 p.

Greeson, P.E., 1971, The limnology of Oneida Lake with emphasis on factors contributing to algal blooms: U.S. Geological Survey Open-File Report, 185 p.

1982, An annotated key to the identification of commonly occurring and dominant genera of algae observed in the phytoplankton of the United States: U.S. Geological Survey Water-Supply Paper 2079, $138 \mathrm{p}$.

Hem, J.D., 1985, Study and interpretation of the chemical characteristics of natural water (3d ed.): U.S. Geological Survey Water-Supply Paper 2254, 263 p.

Hutchinson, G.E., 1957, A treatise on limnology, v. 1-Geography, physics and chemistry: New York, John Wiley, 1,015 p.

1967, A treatise on limnology, v. 2-Introduction to lake biology and the limnoplankton: New York, John Wiley, $1,115 \mathrm{p}$.

Knowlton, M.F., Hoyer, M.V., and Jones, J.R., 1984, Sources of variability in phosphorus and chlorophyll and their effects on use of lake survey data: Water Resources Bulletin, v. 20, no. 3, p. 397-407.

Lerman, Abraham, ed., 1978, Lakes-chemistry, geology, physics: New York, Springer-Verlag, $363 \mathrm{p}$.

McCoy, G.A., 1982, Phytoplankton, in Greeson, P.E., ed., Biota and biological principles of the aquatic environment: U.S. Geological Survey Circular 848-A, p. A17-A21.

National Academy of Sciences, National Academy of Engineering, 1973, Water quality criteria, 1972: Washington, D.C., U.S. Environmental Protection Agency, EPA-R3-73-033, 594 p.

Nicholls, K.H., and Dillon, P.J., 1978, An evaluation of phosphorus-chlorophyll-phytoplankton relationships for lakes: International Revue der Gesamten Hydrobiologie, v. 63, no. 2, p. 141-154.

Organisation for Economic Co-operation and Development, 1982, Eutrophication of water-monitoring, assessment and control: Paris, $154 \mathrm{p}$.

Palmer, C.M., 1977, Algae and water pollution: Cincinnati, Ohio, U.S. Environmental Protection Agency, EPA-600/9-77-036, 123 p.

Ryding, Sven-Olof, 1988, Control of eutrophication of lakes and reservoirs: Cambridge, Eng., Cambridge University Press, 1 v., [UNESCO Man and Biosphere series].

Smith, V.H., 1983, Low nitrogen to phosphorus ratios favor dominance by blue-green algae in lake phytoplankton: Science, v. 221, no. 4611, p. 669-671.

U.S. Environmental Protection Agency, 1986, Quality criteria for water, 1986: EPA 440/5-86-001, 1 v. 
Verduin, Jacob, 1956, Primary production in lakes: Limnology and Oceanography, v. 1, no. 2, p. 85-91.

Wetzel, R. G., 1975, Limnology: Philadelphia, W.B. Saunders, 743 p.

Willingham, W.T., 1976, Ammonia toxicity: U.S. Environmental Protection Agency, EPA-908/3-76-001, 96 p. 


\section{SUPPLEMENTAL DATA}


Table 15. Onsite measurements for all sites at Lake Henry

$\left[{ }^{\circ} \mathrm{C}\right.$, degrees Celsius; $\mathrm{mg} / \mathrm{L}$, milligrams per liter; $\mu \mathrm{S} / \mathrm{cm}$, microsiemens per centimeter at 25 degrees Celsius]

\begin{tabular}{|c|c|c|c|c|c|c|c|}
\hline $\begin{array}{l}\text { Sampling site } \\
\text { (fig. 2) }\end{array}$ & $\begin{array}{l}\text { Sampling } \\
\text { date, } \\
1987\end{array}$ & Time & $\begin{array}{l}\text { Sampling } \\
\text { depth } \\
\text { (feet) }\end{array}$ & $\begin{array}{c}\text { Water } \\
\text { temperature } \\
\left({ }^{\circ} \mathrm{C}\right)\end{array}$ & $\begin{array}{l}\text { Dissolved } \\
\text { oxygen } \\
\text { (mg/L) }\end{array}$ & pH & $\begin{array}{c}\text { Specific } \\
\text { conductance } \\
(\mu \mathrm{S} / \mathrm{cm})\end{array}$ \\
\hline \multirow[t]{16}{*}{ HEW2 } & $05-01$ & 1040 & 0 & 18.0 & 7.3 & 8.3 & 998 \\
\hline & 05-01 & 1041 & 3 & 17.4 & 7.3 & 8.4 & 995 \\
\hline & $05-01$ & 1042 & 6 & 16.1 & 7.2 & 8.3 & 996 \\
\hline & $05-01$ & 1043 & 9 & 15.4 & 6.6 & 8.3 & 998 \\
\hline & 05-01 & 1044 & 10 & 15.3 & 6.5 & 8.2 & 997 \\
\hline & $06-29$ & 1310 & 0 & 22.5 & 6.2 & 8.2 & 889 \\
\hline & $06-29$ & 1311 & 3 & 22.5 & 6.3 & 8.2 & 889 \\
\hline & $06-29$ & 1312 & 6 & 22.5 & 6.1 & 8.2 & 890 \\
\hline & $06-29$ & 1313 & 9 & 22.5 & 6.0 & 8.2 & 890 \\
\hline & $06-29$ & 1314 & 10 & 22.5 & 5.9 & 8.2 & 889 \\
\hline & $08-19$ & 1355 & 0 & 24.7 & 6.9 & 8.6 & 969 \\
\hline & $08-19$ & 1356 & 3 & 22.1 & 6.3 & 8.5 & 973 \\
\hline & 08-19 & 1357 & 6 & 21.5 & 5.3 & 8.4 & 973 \\
\hline & $10-06$ & 1105 & 0 & 14.4 & 7.8 & 8.5 & 1,010 \\
\hline & $10-06$ & 1106 & 3 & 14.4 & 7.8 & 8.5 & 1,010 \\
\hline & $10-06$ & 1107 & 5 & 14.2 & 7.0 & 8.5 & 1,010 \\
\hline \multirow[t]{11}{*}{ HNW } & $05-01$ & 1345 & 0 & 20.2 & 7.7 & 8.4 & 995 \\
\hline & $05-01$ & 1346 & 3 & 19.7 & 7.6 & 8.4 & 995 \\
\hline & $05-01$ & 1347 & 6 & 17.4 & 6.8 & 8.3 & 996 \\
\hline & $05-01$ & 1348 & 8 & 16.9 & 5.6 & 8.2 & 998 \\
\hline & $06-29$ & 1500 & 0 & 22.3 & 6.3 & 8.2 & 900 \\
\hline & $06-29$ & 1501 & 3 & 22.3 & 6.2 & 8.2 & 900 \\
\hline & $06-29$ & 1502 & 6 & 22.3 & 6.2 & 8.2 & 900 \\
\hline & $06-29$ & 1503 & 7 & 22.3 & 6.0 & 8.2 & 900 \\
\hline & $08-19$ & 1530 & 0 & 23.5 & 6.8 & 8.5 & 966 \\
\hline & $08-19$ & 1531 & 3 & 21.9 & 5.2 & 8.4 & 975 \\
\hline & $08-19$ & 1532 & 4 & 21.3 & 4.7 & 8.2 & 976 \\
\hline \multirow[t]{7}{*}{ HSE } & $05-01$ & 1425 & 0 & 20.6 & 7.7 & 8.3 & 998 \\
\hline & $05-01$ & 1426 & 3 & 17.0 & 7.7 & 8.4 & 998 \\
\hline & $05-01$ & 1427 & 6 & 15.8 & 7.6 & 8.4 & 998 \\
\hline & $05-01$ & 1428 & 9 & 14.9 & 6.8 & 8.3 & 1,000 \\
\hline & $06-29$ & 1535 & 0 & 21.4 & 7.3 & 8.3 & 894 \\
\hline & $06-29$ & 1536 & 3 & 21.4 & 7.2 & 8.4 & 895 \\
\hline & $06-29$ & 1537 & 6 & 21.4 & 7.1 & 8.3 & 897 \\
\hline
\end{tabular}


Table 15. Onsite measurements for all sites at Lake Henry--Continued

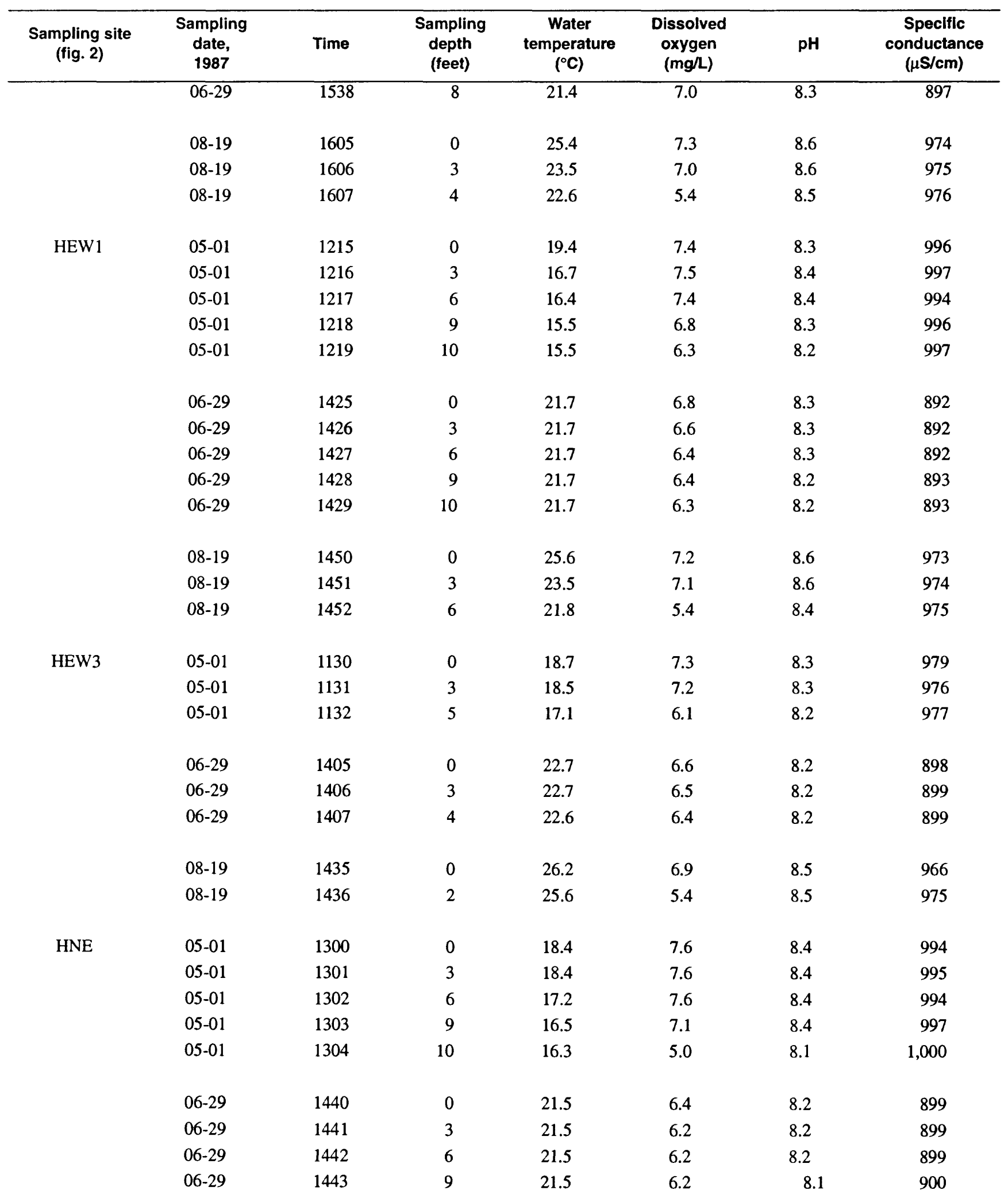


Table 15. Onsite measurements for all sites at Lake Henry--Continued

\begin{tabular}{|c|c|c|c|c|c|c|c|}
\hline $\begin{array}{l}\text { Sampling site } \\
\text { (fig. 2) }\end{array}$ & $\begin{array}{c}\text { Sampling } \\
\text { date, } \\
1987\end{array}$ & Time & $\begin{array}{l}\text { Sampling } \\
\text { depth } \\
\text { (feet) }\end{array}$ & $\begin{array}{c}\text { Water } \\
\text { temperature } \\
\left({ }^{\circ} \mathrm{C}\right)\end{array}$ & $\begin{array}{c}\text { Dissolved } \\
\text { oxygen } \\
\text { (mg/L) }\end{array}$ & $\mathrm{pH}$ & $\begin{array}{c}\text { Specific } \\
\text { conductance } \\
(\mu \mathrm{S} / \mathrm{cm})\end{array}$ \\
\hline & $06-29$ & 1444 & 10 & 21.5 & 6.0 & 8.1 & 900 \\
\hline & $08-19$ & 1510 & 0 & 26.4 & 7.5 & 8.5 & 971 \\
\hline & $08-19$ & 1511 & 3 & 23.2 & 7.0 & 8.5 & 973 \\
\hline & $08-19$ & 1512 & 6 & 22.1 & 5.7 & 8.4 & 980 \\
\hline \multirow[t]{11}{*}{ HSW } & $05-01$ & 1400 & 0 & 20.4 & 7.6 & 8.3 & 998 \\
\hline & $05-01$ & 1401 & 3 & 18.6 & 7.2 & 8.3 & 1,000 \\
\hline & $05-01$ & 1402 & 6 & 16.4 & 6.8 & 8.3 & 998 \\
\hline & $05-01$ & 1403 & 8 & 15.9 & 6.1 & 8.3 & 1,000 \\
\hline & $06-29$ & 1520 & 0 & 22.3 & 6.5 & 8.3 & 899 \\
\hline & $06-29$ & 1521 & 3 & 22.3 & 6.5 & 8.3 & 900 \\
\hline & $06-29$ & 1522 & 6 & 22.3 & 6.7 & 8.2 & 901 \\
\hline & $06-29$ & 1523 & 8 & 22.3 & 6.8 & 8.2 & 901 \\
\hline & $08-19$ & 1550 & 0 & 23.9 & 6.9 & 8.6 & 976 \\
\hline & $08-19$ & 1551 & 3 & 22.9 & 5.0 & 8.4 & 982 \\
\hline & 08-19 & 1552 & 4 & 21.8 & 5.2 & 8.4 & 982 \\
\hline
\end{tabular}


Table 16. Analyses of chemical constituents for site HEW2 at Lake Henry

[NTU, nephelometric turbidity units; mg/L, milligrams per liter; --, no data; <, less than; $\mu \mathrm{g} / \mathrm{L}$, micrograms per liter]

\begin{tabular}{|c|c|c|c|c|c|c|c|c|c|c|}
\hline $\begin{array}{l}\text { Sam- } \\
\text { pling } \\
\text { date, } \\
1987\end{array}$ & Time & $\begin{array}{l}\text { Sam- } \\
\text { pling } \\
\text { depth } \\
\text { (feet) }\end{array}$ & $\begin{array}{l}\text { Turbidity } \\
\text { (NTU) }\end{array}$ & $\begin{array}{l}\text { Nitro- } \\
\text { gen, } \\
\text { nitrate } \\
\text { total } \\
(\mathrm{mg} / \mathrm{L} \\
\text { as } \mathrm{N} \text { ) }\end{array}$ & $\begin{array}{l}\text { Nitro- } \\
\text { gen, } \\
\text { nitrite } \\
\text { total } \\
\text { (mg/L } \\
\text { as } N \text { ) }\end{array}$ & $\begin{array}{c}\text { Nitro- } \\
\text { gen, } \\
\mathrm{NO}_{2}+\mathrm{NO}_{3} \\
\text { total } \\
(\mathrm{mg} / \mathrm{L} \text { as } \\
\mathrm{N})\end{array}$ & $\begin{array}{c}\text { Nitro- } \\
\text { gen, } \\
\mathrm{NO}_{2}+\mathrm{NO}_{3} \\
\text { dissoived } \\
(\mathrm{mg} / \mathrm{L} \text { as } \\
\mathrm{N})\end{array}$ & $\begin{array}{c}\text { Nitro- } \\
\text { gen, } \\
\text { ammonia } \\
\text { total } \\
(\mathrm{mg} / \mathrm{L} \text { as } \\
\mathrm{N})\end{array}$ & $\begin{array}{l}\text { Nitro- } \\
\text { gen, } \\
\text { ammonia } \\
\text { dissoived } \\
\text { (mg/l as } \\
\mathrm{N} \text { ) }\end{array}$ & $\begin{array}{c}\text { Nitro- } \\
\text { gen, } \\
\text { organic } \\
\text { totai } \\
\text { (mg/l } \\
\text { as N) }\end{array}$ \\
\hline $05-01$ & 1100 & 2 & 7.5 & -- & 0.004 & $<0.010$ & 0.017 & 0.130 & 0.147 & 1.2 \\
\hline 05-01 & 1200 & 8 & 12 & 0.009 & .005 & .014 & .044 & .132 & .131 & .87 \\
\hline $06-29$ & 1330 & 2 & 27 & .080 & .011 & .091 & .109 & .092 & .120 & 1.2 \\
\hline $06-29$ & 1400 & 8 & 32 & .082 & .012 & .094 & .102 & .068 & .107 & .83 \\
\hline $08-19$ & 1315 & 2 & 18 & .058 & .005 & .063 & $<.010$ & $<.002$ & .003 & -- \\
\hline $08-19$ & 1415 & 4 & 97 & -- & .007 & $<.010$ & $<.010$ & .045 & .045 & 1.1 \\
\hline $10-06$ & 1120 & 2 & 32 & -- & .003 & $<.010$ & .018 & .074 & .048 & 1.3 \\
\hline $10-06$ & 1125 & 5 & 43 & -- & .004 & $<.010$ & $<.010$ & .054 & .035 & .95 \\
\hline
\end{tabular}

\begin{tabular}{|c|c|c|c|c|c|c|c|c|c|c|c|c|}
\hline $\begin{array}{l}\text { Sam- } \\
\text { pling } \\
\text { date, } \\
1987\end{array}$ & $\begin{array}{c}\text { Nitro- } \\
\text { gen, } \\
\text { ammo- } \\
\text { nia + } \\
\text { organic } \\
\text { total } \\
\text { (mg/L } \\
\text { as } \mathrm{N})\end{array}$ & $\begin{array}{l}\text { Nitro- } \\
\text { gen, } \\
\text { totai } \\
\text { (mg/L } \\
\text { as N) }\end{array}$ & $\begin{array}{c}\text { Phos- } \\
\text { phorus, } \\
\text { totai } \\
\text { (mg/L } \\
\text { as P) }\end{array}$ & $\begin{array}{l}\text { Phos } \\
\text { phoru } \\
\text { dis- } \\
\text { soive } \\
\text { (mg/l } \\
\text { as P) }\end{array}$ & & $\begin{array}{l}\text { Phos- } \\
\text { ohorus, } \\
\text { ortho, } \\
\text { total } \\
\text { (mg/L } \\
\text { as P) }\end{array}$ & $\begin{array}{l}\text { Phos- } \\
\text { phorus, } \\
\text { ortho, } \\
\text { dis- } \\
\text { soived } \\
\text { (mg/L } \\
\text { as P) }\end{array}$ & $\begin{array}{l}\text { Cai- } \\
\text { cium, } \\
\text { dis- } \\
\text { soived } \\
\text { (mg/L } \\
\text { as Ca) }\end{array}$ & $\begin{array}{c}\text { Magne- } \\
\text { sium, } \\
\text { dis- } \\
\text { soived } \\
(\mathrm{mg} / \mathrm{L} \\
\text { as } \mathrm{Mg})\end{array}$ & $\begin{array}{l}\text { Sodi- } \\
\text { um, } \\
\text { dis- } \\
\text { soived } \\
\text { (mg/L } \\
\text { as } \mathrm{Na} \text { ) }\end{array}$ & $\begin{array}{l}\text { Potas- } \\
\text { sium, } \\
\text { dis- } \\
\text { solved } \\
\text { (mg/L } \\
\text { as K) }\end{array}$ & $\begin{array}{c}\text { Alka- } \\
\text { iinity } \\
\text { iab } \\
(\mathrm{mg} / \mathrm{L} \\
\text { as } \\
\left.\mathrm{CaCO}_{3}\right)\end{array}$ \\
\hline $05-01$ & 1.3 & -. & 0.075 & 0.01 & & 0.009 & $<0.001$ & 100 & 31 & 65 & 4.2 & 108 \\
\hline 05-01 & 1.0 & 1.0 & .080 & .00 & 08 & .017 & .001 & 110 & 33 & 67 & 4.4 & 109 \\
\hline $06-29$ & 1.3 & 1.4 & .103 & .02 & 21 & .009 & .002 & 93 & 28 & 57 & 4.7 & 106 \\
\hline $06-29$ & .90 & .99 & .106 & $<.00$ & & .011 & .002 & 90 & 27 & 55 & 4.6 & 107 \\
\hline $08-19$ & .80 & .86 & .031 & .00 & 09 & .014 & .003 & 92 & 31 & 64 & 5.4 & 104 \\
\hline $08-19$ & 1.1 & -- & .030 & .01 & 10 & .015 & .004 & 82 & 27 & 58 & 5.1 & 104 \\
\hline $10-06$ & 1.4 & - & .050 & .08 & 80 & .020 & .051 & 99 & 33 & 72 & 4.9 & 109 \\
\hline $10-06$ & 1.0 & -- & .049 & .04 & 40 & .010 & .023 & 90 & 30 & 65 & 4.4 & 110 \\
\hline $\begin{array}{l}\text { Sam- } \\
\text { pling } \\
\text { date, } \\
1987\end{array}$ & $\begin{array}{c}\text { Sui- } \\
\text { fate, } \\
\text { dis- } \\
\text { solved } \\
\mathrm{(mg/L}^{\text {as }} \\
\text { as } \\
\left.\mathrm{SO}_{4}\right)\end{array}$ & $\begin{array}{l}\text { Chio- } \\
\text { ride, } \\
\text { dis- } \\
\text { soived } \\
\text { (mg/L } \\
\text { as Ci) }\end{array}$ & $\begin{array}{l}\text { Fiuo- } \\
\text { ride, } \\
\text { dis- } \\
\text { soived } \\
\text { (mg/L } \\
\text { as F) }\end{array}$ & $\begin{array}{c}\text { Silica, } \\
\text { dis- } \\
\text { solved } \\
\text { (mg/L } \\
\text { as } \\
\mathrm{SiO}_{2} \text { ) }\end{array}$ & $\begin{array}{c}\text { Solids, } \\
\text { sum } \\
\text { of } \\
\text { consti- } \\
\text { tuents, } \\
\text { dis- } \\
\text { soived } \\
\text { (mg/L) }\end{array}$ & $\begin{array}{c}\text { Arse- } \\
\text { nic, } \\
\text { total } \\
(\mu g / L \\
\text { as As) }\end{array}$ & $\begin{array}{c}\text { Arse- } \\
\text { nic, } \\
\text { dis- } \\
\text { soived } \\
\text { ( } \mu \mathrm{g} / \mathrm{L} \\
\text { as As) }\end{array}$ & $\begin{array}{c}\text { Bari- } \\
\text { um, } \\
\text { totai } \\
\text { recov- } \\
\text { erable } \\
(\mu g / L \\
\text { as } \mathrm{Ba})\end{array}$ & $\begin{array}{c}\text { Bari- } \\
\text { um, } \\
\text { dis- } \\
\text { soived } \\
(\mu g / \mathrm{L} \\
\text { as } \mathrm{Ba})\end{array}$ & $\begin{array}{c}\text { Boron, } \\
\text { total } \\
\text { recov- } \\
\text { erabie } \\
\text { ( } \mu \mathrm{g} / \mathrm{L} \\
\text { as B) }\end{array}$ & $\begin{array}{c}\text { Boron, } \\
\text { dis- } \\
\text { soived } \\
(\mu g / L \\
\text { as B) }\end{array}$ & $\begin{array}{c}\text { Cad- } \\
\text { mium, } \\
\text { totai } \\
\text { recov- } \\
\text { erable } \\
(\mu g / L \\
\text { as Cd) }\end{array}$ \\
\hline $05-01$ & 400 & 25 & 1.0 & 1.4 & 693 & 1 & - & 100 & -- & 120 & -- & $<1$ \\
\hline $05-01$ & 400 & 22 & 0.90 & 1.1 & 704 & $<1$ & -- & 100 & -- & 110 & -- & $<1$ \\
\hline $06-29$ & 340 & 24 & 1.0 & 2.5 & 614 & 2 & 1 & 100 & 83 & 120 & 110 & $<1$ \\
\hline $06-29$ & 330 & 23 & 0.80 & 2.6 & 598 & 2 & 1 & 100 & 86 & 90 & 110 & $<1$ \\
\hline $08-19$ & 370 & 18 & 1.1 & 5.4 & 650 & 2 & 1 & 200 & 92 & 150 & 130 & 1 \\
\hline $08-19$ & 370 & 18 & 1.1 & 4.9 & 629 & 4 & 1 & 200 & 83 & 130 & 130 & 1 \\
\hline $10-06$ & 400 & 21 & 1.1 & 7.0 & 704 & 4 & -- & 100 & -- & 150 & -- & $<1$ \\
\hline $10-06$ & 410 & 21 & 1.1 & 6.3 & 694 & 4 & -- & 100 & -- & 140 & -- & $<1$ \\
\hline
\end{tabular}


Table 16. Analyses of chemical constituents for site HEW2 at Lake Henry--Continued

\begin{tabular}{|c|c|c|c|c|c|c|c|c|c|c|c|}
\hline $\begin{array}{l}\text { Sam- } \\
\text { pling } \\
\text { date, } \\
1987\end{array}$ & $\begin{array}{l}\text { Cad- } \\
\text { mium } \\
\text { dis- } \\
\text { solved } \\
(\mu g / L \text { as } \\
\text { Cd) }\end{array}$ & $\begin{array}{c}\text { Chro- } \\
\text { mium, } \\
\text { total } \\
\text { recov- } \\
\text { erabie } \\
(\mu \mathrm{g} / \mathrm{L} \text { as } \\
\mathrm{Cr})\end{array}$ & $\begin{array}{l}\text { Chro- } \\
\text { mium, } \\
\text { dis- } \\
\text { solved } \\
(\mu \mathrm{g} / \mathrm{L} \text { as } \\
\text { Cr) }\end{array}$ & $\begin{array}{c}\text { Copper, } \\
\text { total } \\
\text { recov- } \\
\text { erable } \\
\text { ( } \mu \text { g/Las } \\
\text { Cu) }\end{array}$ & $\begin{array}{l}\text { Copper, } \\
\text { dis- } \\
\text { solved } \\
(\mu g / L a s \\
\text { Cu) }\end{array}$ & $\begin{array}{c}\text { Iron, } \\
\text { totai } \\
\text { recov- } \\
\text { erable } \\
\text { ( } \mu \text { g/Las } \\
\text { Fe) }\end{array}$ & $\begin{array}{c}\text { Iron, } \\
\text { dis- } \\
\text { solved } \\
(\mu \mathrm{g} / \mathrm{L} \text { as } \\
\text { Fe) }\end{array}$ & $\begin{array}{c}\text { Lead, } \\
\text { total } \\
\text { recov- } \\
\text { erable } \\
\text { ( } \mu \mathrm{g} / \mathrm{L} \text { as } \\
\text { Pb) }\end{array}$ & $\begin{array}{l}\text { Lead, } \\
\text { dis- } \\
\text { solved } \\
(\mu \mathrm{g} / \mathrm{Las} \\
\mathrm{Pb})\end{array}$ & $\begin{array}{c}\text { Manga- } \\
\text { nese, } \\
\text { total } \\
\text { recov- } \\
\text { erable } \\
(\mu \mathrm{g} / \mathrm{L} \text { as } \\
\mathrm{Mn})\end{array}$ & $\begin{array}{c}\text { Manga- } \\
\text { nese, } \\
\text { dis- } \\
\text { solved } \\
\text { ( } \mu \text { g/las } \\
\text { Mn) }\end{array}$ \\
\hline $05-01$ & -- & 5 & - & 6 & -- & 440 & - & $<5$ & -- & 50 & - \\
\hline $05-01$ & - & 25 & - & 8 & -- & 420 & -- & $<5$ & -- & 50 & -- \\
\hline $06-29$ & $<1$ & $<10$ & $<10$ & 3 & 2 & 860 & 11 & $<5$ & $<5$ & 70 & 16 \\
\hline $06-29$ & $<1$ & - & $<10$ & 4 & 1 & 990 & 55 & $<5$ & $<5$ & 70 & 14 \\
\hline 08-19 & $<1$ & $<10$ & 10 & 4 & 1 & 1,000 & $<3$ & $<5$ & $<5$ & 160 & 3 \\
\hline $08-19$ & $<1$ & 10 & 10 & 11 & 1 & 6,300 & 9 & 7 & $<5$ & 260 & 9 \\
\hline $10-06$ & -- & 4 & -- & 5 & -- & 1,900 & -- & 6 & -- & 240 & -- \\
\hline $10-06$ & -. & 3 & -- & 5 & - & 2,500 & -- & 6 & -- & 240 & -- \\
\hline $\begin{array}{l}\text { Sam- } \\
\text { pling } \\
\text { date, } \\
1987\end{array}$ & $\begin{array}{c}\text { Mercury, } \\
\text { total } \\
\text { recov- } \\
\text { erable } \\
(\mu \mathrm{g} / \mathrm{L} \text { as } \\
\mathrm{Hg})\end{array}$ & $\begin{array}{c}\text { Mercury, } \\
\text { dis- } \\
\text { solved } \\
(\mu \mathrm{g} / \mathrm{L} \text { as } \\
\mathrm{Hg})\end{array}$ & $\begin{array}{c}\text { Nickel, } \\
\text { total } \\
\text { recov- } \\
\text { erabie } \\
(\mu \mathrm{g} / \mathrm{L} \text { as } \\
\mathrm{Ni})\end{array}$ & $\begin{array}{c}\text { Nickel, } \\
\text { dis- } \\
\text { solved } \\
(\mu \mathrm{g} / \mathrm{L} \text { as } \\
\mathrm{Ni})\end{array}$ & & & $\begin{array}{l}\text { ile- } \\
\text { um, } \\
\text { is- } \\
\text { ved } \\
\text { L as } \\
\text { e) }\end{array}$ & $\begin{array}{c}\text { Silver, } \\
\text { total } \\
\text { recov- } \\
\text { erable } \\
(\mu \mathrm{g} / \mathrm{L} \text { as } \\
\mathrm{Ag})\end{array}$ & $\begin{array}{c}\text { Silver, } \\
\text { dis- } \\
\text { solved } \\
(\mu \mathrm{g} / \mathrm{L} \text { as } \\
\mathrm{Ag})\end{array}$ & $\begin{array}{c}\text { Zinc, } \\
\text { totai } \\
\text { recov- } \\
\text { erable } \\
(\mu \mathrm{g} / \mathrm{L} \text { as } \\
\mathrm{Zn})\end{array}$ & $\begin{array}{c}\text { Zinc, } \\
\text { dis- } \\
\text { solved } \\
(\mu \mathrm{g} / \mathrm{L} \text { as } \\
\mathrm{Zn})\end{array}$ \\
\hline $05-01$ & $<0.1$ & -- & 3 & -- & & & - & $<1$ & -- & 20 & -- \\
\hline $05-01$ & $<.1$ & -- & 7 & -- & & & -- & $<1$ & -- & 20 & - \\
\hline $06-29$ & $<.1$ & $<0.1$ & $<1$ & 3 & & & 3 & $<1$ & $<1.0$ & $<10$ & 6 \\
\hline $06-29$ & $<.1$ & $<.1$ & 3 & 4 & & & 3 & $<1$ & $<1.0$ & 10 & 9 \\
\hline 08-19 & $<.1$ & $<.1$ & 4 & $<1$ & & & 3 & $<1$ & $<1.0$ & 40 & 3 \\
\hline 08-19 & $<.1$ & $<.1$ & 13 & $<1$ & & & 3 & $<1$ & $<1.0$ & 40 & 4 \\
\hline $10-06$ & -- & $\cdots$ & 6 & -- & & & -- & $<1$ & -- & $<10$ & -- \\
\hline $10-06$ & $<.1$ & -- & 6 & -- & & & -- & $<1$ & -- & $<10$ & -- \\
\hline
\end{tabular}


Table 17. Phytoplankton densities for site HEW2 at Lake Henry

[cells/mL, cells per milliliter; dashes indicate taxa not detected; var., identifies a variation in the species; sp., species are distinguishable but not identifiable. Densities are rounded to standard significant figures (Britton and Greeson, 1989]

\begin{tabular}{|c|c|c|c|c|}
\hline \multirow{2}{*}{ Taxa } & \multicolumn{4}{|c|}{ Densities (cells/mL) for indicated sampling date } \\
\hline & $05-01-87$ & $06-29-87$ & 08-19-87 & $10-06-87$ \\
\hline \multicolumn{5}{|l|}{ BACILLARIOPHYTA (Diatoms) } \\
\hline \multicolumn{5}{|l|}{ Order Centrales } \\
\hline Attheya zachariasi & -- & 57 & -- & -- \\
\hline Cyclotella kutzingiana & -- & - & 110 & -- \\
\hline Cyclotella meneghiniana & - & -- & 110 & -- \\
\hline Cyclotella ocellata & 14 & -- & -- & -- \\
\hline Cyclotella stelligera & 110 & 110 & -- & -- \\
\hline Melosira granulata & - & 230 & -- & -- \\
\hline Melosira granulata var. angustissima & -- & 1,600 & 110 & 1,900 \\
\hline Melosira italica & -- & 450 & -- & -- \\
\hline Stephanodiscus dubius & -- & -- & 800 & - \\
\hline Stephanodiscus niagarae & 28 & -- & -- & -- \\
\hline Stephanodiscus sp. & -- & - & -- & 340 \\
\hline \multicolumn{5}{|l|}{ Order Pennales } \\
\hline Fragilaria crotonensis & 28 & 910 & -- & -- \\
\hline Neidium sp. & -- & -- & 110 & -- \\
\hline Nitzschia acicularis & 7 & 57 & -- & 110 \\
\hline Nitzschia intermedia & -- & -- & -- & 110 \\
\hline Nitzschia longissi & -- & - & 110 & -- \\
\hline Nitzschia palea & -- & -. & 110 & -- \\
\hline Nitzschia sp. & - & 57 & -- & - \\
\hline Synedra acus & - & -- & 57 & - \\
\hline \multicolumn{5}{|l|}{ CHLOROPHYTA (Green algae) } \\
\hline Ankistrodesmus braunii & 57 & -- & -- & - \\
\hline Ankistrodesmus convolutus & -- & -- & -- & 800 \\
\hline Ankistrodesmus falcatus & - & -- & 57 & -- \\
\hline Ankistrodesmus falcatus var. falcatus & -- & -- & -- & 450 \\
\hline Ankistrodesmus falcatus var. mirabilis & -- & -- & - & 110 \\
\hline Ankistrodesmus nannoselene & -- & -- & 340 & -- \\
\hline Chlamydomonas sp. & - & 57 & 230 & -- \\
\hline Chlamydomonas sp. 1 & -- & - & -- & 450 \\
\hline Chlorella sp. & 3,300 & -- & 450 & 450 \\
\hline Chlorococcum sp. & 170 & 230 & -- & 230 \\
\hline Chodatella longiseta & -- & - & 110 & -- \\
\hline Chodatella quadriseta & -- & - & -- & 450 \\
\hline Chodatella wratislawiensis & -- & -- & 57 & 230 \\
\hline Closterium sp. & -- & -- & -- & 230 \\
\hline Coccomyxa minor & 1,400 & 1,800 & -- & -- \\
\hline Crucigena tetrapedia & - & -- & -- & 450 \\
\hline
\end{tabular}


Table 17. Phytoplankton densities for site HEW2 at Lake Henry--Continued

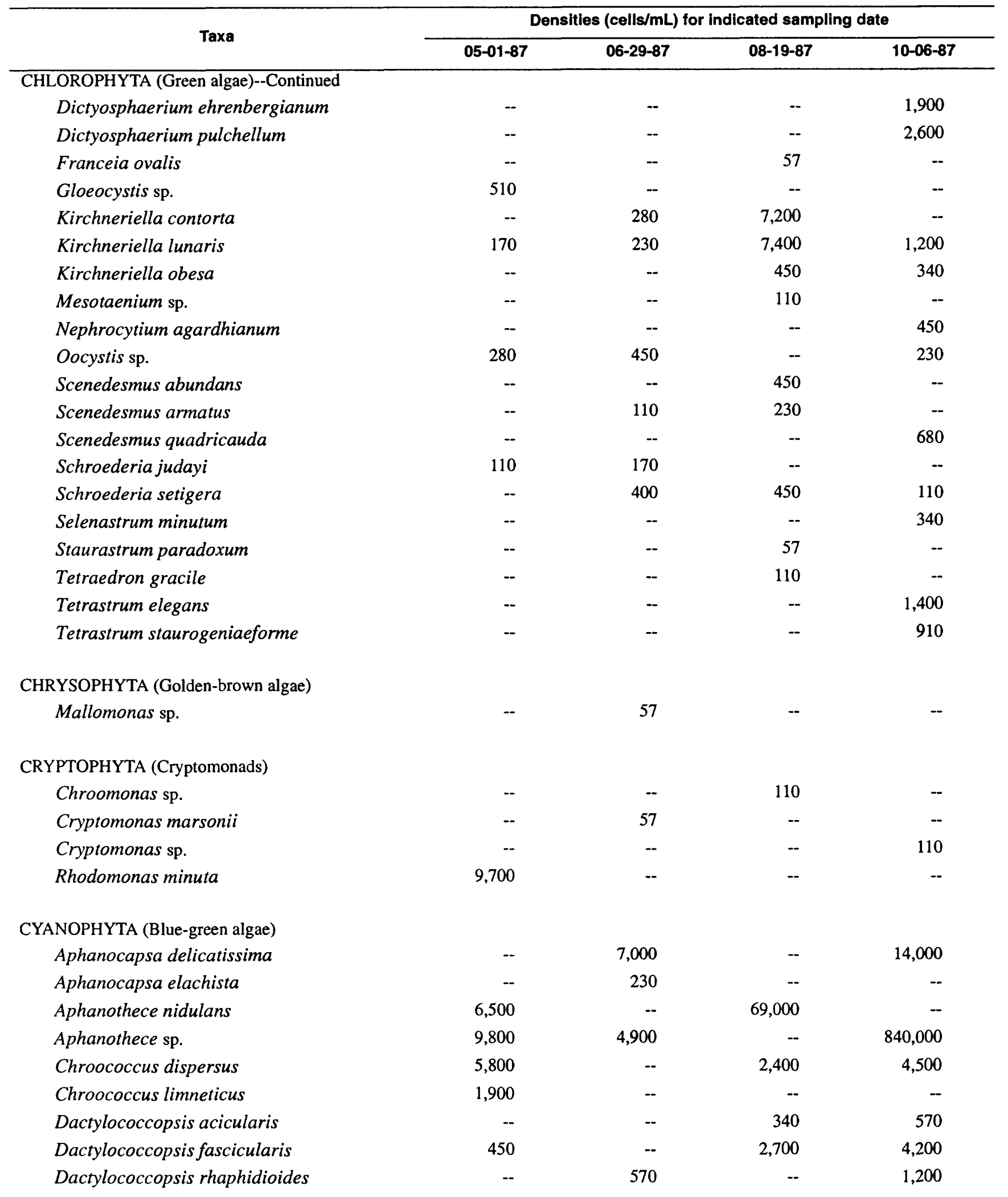

40 Reconnaissance of Water Quality of Lake Henry and Lake Meredith Reservoir, Crowley County, Southeastern Colorado, April-October 1987 
Table 17. Phytoplankton densities for site HEW2 at Lake Henry--Continued

\begin{tabular}{|c|c|c|c|c|}
\hline \multirow{2}{*}{ Taxa } & \multicolumn{4}{|c|}{ Densities (ceiis $/ \mathrm{mL}$ ) for indicated sampiing date } \\
\hline & $05-01-87$ & 06-29-87 & $08-19-87$ & $10-06-87$ \\
\hline \multicolumn{5}{|c|}{ CYANOPHYTA (Blue-green algae)--Continued } \\
\hline Dactylococcopsis sp. & 570 & 340 & - & -- \\
\hline Lyngbya limnetica & -- & -- & - & 5,700 \\
\hline Merismopedia tenuissima & -- & -- & 4,300 & - \\
\hline Microcystis incerta & -- & -- & 830,000 & -- \\
\hline Microcystis sp. & 4,500 & -- & - & - \\
\hline Oscillatoria angustissima & -- & -- & 4,100 & 12,000 \\
\hline Oscillatoria limnetica & - & - & -- & 2,300 \\
\hline Oscillatoria tenuis & -- & -. & 1,800 & -- \\
\hline Synechococcus sp. & 6,500 & 13,000 & -- & -- \\
\hline \multicolumn{5}{|l|}{ EUGLENOPHYTA (Euglenoids) } \\
\hline Euglena acus & -- & $-\cdot$ & 110 & 57 \\
\hline Euglena oxyuris var. minor & -- & -- & 110 & 340 \\
\hline Trachelomonas gibberosa & -- & -- & 110 & -- \\
\hline Trachelomonas planctonica & -- & -- & 57 & 110 \\
\hline Total, cells/mL & 52,000 & 33,000 & 930,000 & 900,000 \\
\hline Number of species & 22 & 25 & 37 & 38 \\
\hline
\end{tabular}


Table 18. Onsite measurements for all sites at Lake Meredith

$\left[{ }^{\circ} \mathrm{C}\right.$, degrees Celsius; $\mathrm{mg} / \mathrm{L}$, milligrams per liter; $\mu \mathrm{S} / \mathrm{cm}$, microsiemens per centimeter at 25 degrees Celsius]

\begin{tabular}{|c|c|c|c|c|c|c|c|}
\hline $\begin{array}{l}\text { Sampling site } \\
\text { (fig. } 3 \text { ) }\end{array}$ & $\begin{array}{c}\text { Sampiing } \\
\text { date, } \\
1987\end{array}$ & Time & $\begin{array}{l}\text { Sampiing } \\
\text { depth } \\
\text { (feet) }\end{array}$ & $\begin{array}{c}\text { Water } \\
\text { temperature } \\
\left({ }^{\circ} \mathrm{C}\right)\end{array}$ & $\begin{array}{l}\text { Dissoived } \\
\text { oxygen } \\
\text { (mg/L) }\end{array}$ & pH & $\begin{array}{c}\text { Specific } \\
\text { conductance } \\
(\mu \mathrm{S} / \mathrm{cm})\end{array}$ \\
\hline \multirow[t]{20}{*}{ M2B } & $05-01$ & 1550 & 0 & 21.7 & 9.8 & 8.6 & 2,600 \\
\hline & $05-01$ & 1551 & 3 & 17.5 & 10.3 & 8.7 & 2,600 \\
\hline & $05-01$ & 1552 & 6 & 16.7 & 8.6 & 8.6 & 2,610 \\
\hline & $05-01$ & 1553 & 9 & 16.1 & 7.6 & 8.4 & 2,600 \\
\hline & $05-01$ & 1554 & 12 & 15.4 & 4.9 & 8.1 & 2,600 \\
\hline & $05-01$ & 1555 & 13 & 15.3 & 4.7 & 8.0 & 2,600 \\
\hline & $06-30$ & 1040 & 0 & 21.1 & 6.5 & 8.3 & 2,580 \\
\hline & $06-30$ & 1041 & 3 & 21.1 & 6.4 & 8.2 & 2,580 \\
\hline & $06-30$ & 1042 & 6 & 21.1 & 6.3 & 8.2 & 2,580 \\
\hline & $06-30$ & 1043 & 9 & 21.1 & 6.3 & 8.2 & 2,580 \\
\hline & $06-30$ & 1044 & 12 & 21.0 & 5.6 & 8.1 & 2,580 \\
\hline & $06-30$ & 1045 & 13 & 21.1 & 5.1 & 8.1 & 2,580 \\
\hline & $08-20$ & 1050 & 0 & 22.9 & 6.7 & 8.4 & 2,930 \\
\hline & $08-20$ & 1051 & 3 & 22.3 & 6.0 & 8.3 & 2,930 \\
\hline & $08-20$ & 1052 & 6 & 21.5 & 5.4 & 8.3 & 2,940 \\
\hline & $08-20$ & 1053 & 8 & 21.0 & 4.1 & 8.2 & 2,940 \\
\hline & $10-06$ & 1425 & 0 & 17.2 & 8.1 & 8.6 & 3,000 \\
\hline & $10-06$ & 1426 & 3 & 16.0 & 7.4 & 8.6 & 3,010 \\
\hline & $10-06$ & 1427 & 6 & 15.6 & 6.8 & 8.5 & 3,010 \\
\hline & $10-06$ & 1428 & 8 & 15.4 & 5.2 & 8.4 & 3,030 \\
\hline \multirow[t]{17}{*}{ M1B } & $05-01$ & 1720 & 0 & 19.7 & 9.9 & 8.6 & 2,600 \\
\hline & $05-01$ & 1721 & 3 & 19.6 & 9.9 & 8.7 & 2,600 \\
\hline & $05-01$ & 1722 & 6 & 19.3 & 9.9 & 8.7 & 2,600 \\
\hline & $05-01$ & 1723 & 9 & 17.6 & 7.9 & 8.5 & 2,600 \\
\hline & $05-01$ & 1724 & 12 & 15.8 & 6.1 & 8.3 & 2,610 \\
\hline & $05-01$ & 1725 & 14 & 15.3 & 5.8 & 8.1 & 2,600 \\
\hline & $06-30$ & 1305 & 0 & 21.7 & 5.2 & 8.2 & 2,520 \\
\hline & $06-30$ & 1306 & 3 & 21.8 & 5.0 & 8.1 & 2,520 \\
\hline & $06-30$ & 1307 & 6 & 21.8 & 4.9 & 8.1 & 2,530 \\
\hline & $06-30$ & 1308 & 9 & 21.7 & 4.9 & 8.1 & 2,530 \\
\hline & $06-30$ & 1309 & 12 & 21.8 & 4.9 & 8.1 & 2,540 \\
\hline & $06-30$ & 1310 & 15 & 21.8 & 4.4 & 8.1 & 2,550 \\
\hline & $08-20$ & 1300 & 0 & 25.1 & 7.8 & 8.5 & 2,920 \\
\hline & $08-20$ & 1301 & 3 & 23.6 & 7.0 & 8.5 & 2,910 \\
\hline & $08-20$ & 1302 & 6 & 22.9 & 2.8 & 8.1 & 2,910 \\
\hline & $08-20$ & 1303 & 9 & 22.1 & 3.4 & 8.1 & 2,920 \\
\hline & $08-20$ & 1304 & 10 & 21.7 & 2.9 & 8.1 & 2,920 \\
\hline
\end{tabular}


Table 18. Onsite measurements for all sites at Lake Meredith--Continued

\begin{tabular}{|c|c|c|c|c|c|c|c|}
\hline $\begin{array}{l}\text { Sampling site } \\
\text { (fig. 3) }\end{array}$ & $\begin{array}{l}\text { Sampling } \\
\text { date, } \\
1987\end{array}$ & Time & $\begin{array}{l}\text { Sampling } \\
\text { depth } \\
\text { (feet) }\end{array}$ & $\begin{array}{c}\text { Water } \\
\text { temperature } \\
\left({ }^{\circ} \mathrm{C}\right)\end{array}$ & $\begin{array}{l}\text { Dissolved } \\
\text { oxygen } \\
\text { (mg/L) }\end{array}$ & $\mathrm{pH}$ & $\begin{array}{c}\text { Specific } \\
\text { conductance } \\
(\mu S / \mathrm{cm})\end{array}$ \\
\hline \multirow[t]{13}{*}{ M4B } & $05-01$ & 1850 & 0 & 19.3 & 8.6 & 8.6 & 2,640 \\
\hline & $05-01$ & 1851 & 3 & 19.3 & 8.6 & 8.6 & 2,640 \\
\hline & $05-01$ & 1852 & 6 & 19.3 & 8.4 & 8.6 & 2,640 \\
\hline & $05-01$ & 1853 & 9 & 17.3 & 6.5 & 8.4 & 2,640 \\
\hline & $05-01$ & 1854 & 11 & 17.2 & 6.4 & 8.4 & 2,640 \\
\hline & $06-30$ & 1455 & 0 & 21.0 & 6.4 & 8.3 & 2,600 \\
\hline & $06-30$ & 1456 & 3 & 21.0 & 6.2 & 8.3 & 2,600 \\
\hline & $06-30$ & 1457 & 6 & 21.0 & 6.0 & 8.2 & 2,600 \\
\hline & $06-30$ & 1458 & 9 & 20.7 & 4.2 & 8.0 & 2,610 \\
\hline & $06-30$ & 1459 & 10 & 20.6 & 3.8 & 8.0 & 2,610 \\
\hline & $08-21$ & 1010 & 0 & 23.2 & 6.4 & 8.5 & 2,980 \\
\hline & $08-21$ & 1011 & 3 & 22.0 & 5.5 & 8.5 & 3,020 \\
\hline & $08-21$ & 1012 & 6 & 21.4 & 4.4 & 8.4 & 3,030 \\
\hline \multirow[t]{10}{*}{ M1A } & $06-30$ & 1205 & 0 & 21.7 & 5.7 & 8.2 & 2,540 \\
\hline & $06-30$ & 1206 & 3 & 21.7 & 5.6 & 8.1 & 2,540 \\
\hline & $06-30$ & 1207 & 6 & 21.7 & 5.5 & 8.1 & 2,550 \\
\hline & $06-30$ & 1208 & 9 & 21.7 & 5.4 & 8.1 & 2,550 \\
\hline & $06-30$ & 1209 & 12 & 21.7 & 5.3 & 8.1 & 2,560 \\
\hline & $06-30$ & 1210 & 14 & 21.7 & 4.7 & 8.1 & 2,570 \\
\hline & $08-20$ & 1350 & 0 & 25.9 & 7.8 & 8.5 & 2,910 \\
\hline & $08-20$ & 1351 & 3 & 24.2 & 6.9 & 8.5 & 2,920 \\
\hline & $08-20$ & 1352 & 6 & 23.6 & 5.9 & 8.4 & 2,920 \\
\hline & $08-20$ & 1353 & 9 & 22.7 & 1.4 & 7.9 & 2,930 \\
\hline \multirow[t]{9}{*}{$\mathrm{M} 1 \mathrm{C}$} & $06-30$ & 1245 & 0 & 21.5 & 5.7 & 8.2 & 2,530 \\
\hline & $06-30$ & 1246 & 3 & 21.5 & 5.6 & 8.2 & 2,520 \\
\hline & $06-30$ & 1247 & 6 & 21.6 & 5.7 & 8.2 & 2,520 \\
\hline & $06-30$ & 1248 & 9 & 21.6 & 5.5 & 8.2 & 2,520 \\
\hline & $06-30$ & 1249 & 12 & 21.6 & 5.3 & 8.1 & 2,530 \\
\hline & $08-20$ & 1420 & 0 & 27.9 & 9.1 & 8.6 & 2,930 \\
\hline & $08-20$ & 1421 & 3 & 24.7 & 9.4 & 8.6 & 2,930 \\
\hline & $08-20$ & 1422 & 6 & 23.5 & 8.0 & 8.6 & 2,940 \\
\hline & $08-20$ & 1423 & 7 & 22.7 & 5.9 & 8.4 & 2,960 \\
\hline \multirow[t]{3}{*}{$\mathrm{M} 2 \mathrm{~A}$} & $06-30$ & 1110 & 0 & 21.3 & 6.4 & 8.2 & 2,570 \\
\hline & $06-30$ & 1111 & 3 & 21.3 & 6.3 & 8.2 & 2,570 \\
\hline & $06-30$ & 1112 & 6 & 21.3 & 6.2 & 8.2 & 2,570 \\
\hline
\end{tabular}


Table 18. Onsite measurements for all sites at Lake Meredith--Continued

\begin{tabular}{|c|c|c|c|c|c|c|c|}
\hline $\begin{array}{l}\text { Sampling site } \\
\text { (fig. 3) }\end{array}$ & $\begin{array}{c}\text { Sampling } \\
\text { date, } \\
1987\end{array}$ & Time & $\begin{array}{l}\text { Sampling } \\
\text { depth } \\
\text { (feet) }\end{array}$ & $\begin{array}{c}\text { Water } \\
\text { temperature } \\
\left({ }^{\circ} \mathrm{C}\right)\end{array}$ & $\begin{array}{l}\text { Dissoived } \\
\text { oxygen } \\
\text { (mg/L) }\end{array}$ & $\mathrm{pH}$ & $\begin{array}{c}\text { Specific } \\
\text { conductance } \\
(\mu \mathrm{S} / \mathrm{cm})\end{array}$ \\
\hline \multicolumn{8}{|c|}{ M2A--Continued } \\
\hline & $06-30$ & 1113 & 9 & 21.3 & 6.2 & 8.2 & 2,570 \\
\hline & $06-30$ & 1114 & 12 & 21.3 & 6.2 & 8.2 & 2,570 \\
\hline & $06-30$ & 1115 & 15 & 21.3 & 4.4 & 8.0 & 2,580 \\
\hline & $08-20$ & 1205 & 0 & 23.9 & 7.9 & 8.6 & 2,920 \\
\hline & $08-20$ & 1206 & 3 & 23.0 & 5.6 & 8.4 & 2,910 \\
\hline & $08-20$ & 1207 & 6 & 22.1 & 5.3 & 8.4 & 2,930 \\
\hline & $08-20$ & 1208 & 9 & 21.6 & 4.5 & 8.2 & 2,940 \\
\hline \multirow[t]{9}{*}{$\mathrm{M} 2 \mathrm{C}$} & $06-30$ & 1135 & 0 & 21.0 & 6.5 & 8.3 & 2,570 \\
\hline & $06-30$ & 1136 & 3 & 21.0 & 6.4 & 8.3 & 2,580 \\
\hline & $06-30$ & 1137 & 6 & 21.0 & 6.3 & 8.3 & 2,580 \\
\hline & $06-30$ & 1138 & 9 & 21.0 & 6.2 & 8.3 & 2,580 \\
\hline & $06-30$ & 1139 & 10 & 21.0 & 6.1 & 8.2 & 2,580 \\
\hline & $08-20$ & 1140 & 0 & 22.5 & 6.9 & 8.4 & 2,930 \\
\hline & $08-20$ & 1141 & 3 & 22.3 & 6.7 & 8.4 & 2,940 \\
\hline & $08-20$ & 1142 & 6 & 21.2 & 5.6 & 8.3 & 2,940 \\
\hline & $08-20$ & 1143 & 8 & 20.9 & 4.8 & 8.2 & 2,940 \\
\hline \multirow[t]{8}{*}{ M3A } & $06-30$ & 1425 & 0 & 21.9 & 6.0 & 8.2 & 2,570 \\
\hline & $06-30$ & 1426 & 3 & 21.9 & 5.9 & 8.2 & 2,580 \\
\hline & $06-30$ & 1427 & 6 & 21.8 & 5.7 & 8.2 & 2,580 \\
\hline & $06-30$ & 1428 & 9 & 21.7 & 5.4 & 8.1 & 2,580 \\
\hline & $06-30$ & 1429 & 10 & 21.7 & 5.0 & 8.1 & 2,580 \\
\hline & $08-21$ & 1115 & 0 & 24.0 & 7.0 & 8.5 & 2,950 \\
\hline & $08-21$ & 1116 & 3 & 23.0 & 6.9 & 8.5 & 2,950 \\
\hline & $08-21$ & 1117 & 6 & 22.5 & 4.9 & 8.3 & 2,950 \\
\hline \multirow[t]{8}{*}{ M3B } & $06-30$ & 1405 & 0 & 21.7 & 6.7 & 8.3 & 2,550 \\
\hline & $06-30$ & 1406 & 3 & 21.7 & 6.6 & 8.3 & 2,550 \\
\hline & $06-30$ & 1407 & 6 & 21.7 & 6.4 & 8.2 & 2,560 \\
\hline & $06-30$ & 1408 & 9 & 21.6 & 5.7 & 8.2 & 2,560 \\
\hline & $06-30$ & 1409 & 10 & 21.6 & 5.5 & 8.1 & 2,570 \\
\hline & $08-21$ & 1100 & 0 & 23.0 & 6.6 & 8.5 & 2,940 \\
\hline & $08-21$ & 1101 & 3 & 22.3 & 6.2 & 8.5 & 2,950 \\
\hline & $08-21$ & 1102 & 6 & 21.8 & 4.5 & 8.3 & 2,980 \\
\hline \multirow[t]{2}{*}{ M4A } & $06-30$ & 1515 & 0 & 21.6 & 6.6 & 8.3 & 2,570 \\
\hline & $06-30$ & 1516 & 3 & 21.6 & 6.5 & 8.3 & 2,570 \\
\hline
\end{tabular}


Table 18. Onsite measurements for all sites at Lake Meredith--Continued

\begin{tabular}{|c|c|c|c|c|c|c|c|}
\hline $\begin{array}{l}\text { Sampling site } \\
\text { (fig. 3) }\end{array}$ & $\begin{array}{c}\text { Sampling } \\
\text { date, } \\
1987\end{array}$ & Time & $\begin{array}{l}\text { Sampling } \\
\text { depth } \\
\text { (feet) }\end{array}$ & $\begin{array}{c}\text { Water } \\
\text { temperature } \\
\left({ }^{\circ} \mathrm{C}\right)\end{array}$ & $\begin{array}{c}\text { Dissolved } \\
\text { oxygen } \\
(\mathrm{mg} / \mathrm{L})\end{array}$ & $\mathrm{pH}$ & $\begin{array}{c}\text { Speclfic } \\
\text { conductance } \\
(\mu \mathrm{S} / \mathrm{cm})\end{array}$ \\
\hline \multicolumn{8}{|c|}{ M4A--Continued } \\
\hline & $06-30$ & 1517 & 6 & 21.5 & 6.4 & 8.3 & 2,570 \\
\hline & $08-21$ & 1025 & 0 & 23.9 & 6.1 & 8.5 & 3,040 \\
\hline & $08-21$ & 1026 & 2 & 22.8 & 6.0 & 8.5 & 3,040 \\
\hline
\end{tabular}


Table 19. Analyses of chemical constituents for site M2B at Lake Meredith

[NTU, nephelometric turbidity units; $\mathrm{mg} / \mathrm{L}$, milligrams per liter; dashes indicate no data; <, less than; $\mu \mathrm{g} / \mathrm{L}$, micrograms per liter]

\begin{tabular}{|c|c|c|c|c|c|c|c|c|c|c|c|}
\hline $\begin{array}{l}\text { Sam- } \\
\text { pling } \\
\text { date, } \\
1987\end{array}$ & Time & $\begin{array}{l}\text { Sam- } \\
\text { pling } \\
\text { depth } \\
\text { (feet) }\end{array}$ & $\begin{array}{c}\text { Turbid- } \\
\text { ity } \\
\text { (NTU) }\end{array}$ & $\begin{array}{l}\text { Nitro- } \\
\text { gen, } \\
\text { nitrate } \\
\text { total } \\
\text { (mg/L } \\
\text { as N) }\end{array}$ & $\begin{array}{l}\text { Nitro- } \\
\text { gen, } \\
\text { nitrite } \\
\text { total } \\
\text { (mg/L } \\
\text { as N) }\end{array}$ & $\begin{array}{l}\text { Nitro- } \\
\text { gen, } \\
\mathrm{NO}_{2+} \\
\mathrm{NO}_{3} \\
\text { total } \\
\text { (mg/l } \\
\text { as } \mathrm{N} \text { ) }\end{array}$ & $\begin{array}{c}\text { Nitro- } \\
\text { gen, } \\
\mathrm{NO}_{2+} \\
\mathrm{NO}_{3} \\
\text { dis- } \\
\text { solved } \\
\text { (mg/ } \\
\text { as } \mathrm{N} \text { ) }\end{array}$ & $\begin{array}{l}\text { Nitro- } \\
\text { gen, } \\
\text { ammo- } \\
\text { nia } \\
\text { total } \\
\text { (mg/L } \\
\text { as } \mathrm{N} \text { ) }\end{array}$ & $\begin{array}{c}\text { Nitro- } \\
\text { gen, } \\
\text { ammo- } \\
\text { nia } \\
\text { dis- } \\
\text { solved } \\
\text { (mg/L } \\
\text { as } \mathrm{N} \text { ) }\end{array}$ & $\begin{array}{c}\text { Nitro- } \\
\text { gen, } \\
\text { organlc } \\
\text { total } \\
\text { (mg/L } \\
\text { as N) }\end{array}$ & $\begin{array}{c}\text { Nitro- } \\
\text { gen, } \\
\text { ammo- } \\
\text { nla + } \\
\text { organic } \\
\text { total } \\
\text { (mg/l } \\
\text { as } \mathrm{N} \text { ) }\end{array}$ \\
\hline $05-01$ & 1620 & 10 & 7.0 & -- & .003 & $<.010$ & $<.010$ & .173 & .143 & 1.4 & 1.6 \\
\hline $06-30$ & 1015 & 2 & 17 & -- & .004 & $<.010$ & $<.010$ & .115 & .091 & 1.6 & 1.7 \\
\hline $06-30$ & 1100 & 11 & 18 & -- & .004 & $<.010$ & .015 & .103 & .104 & 1.2 & 1.3 \\
\hline $08-20$ & 1045 & 2 & 16 & 0.010 & .007 & .017 & .011 & .082 & .102 & 1.2 & 1.3 \\
\hline $08-20$ & 1130 & 6 & 17 & -- & .007 & $<.010$ & .018 & .092 & .084 & 1.4 & 1.5 \\
\hline
\end{tabular}

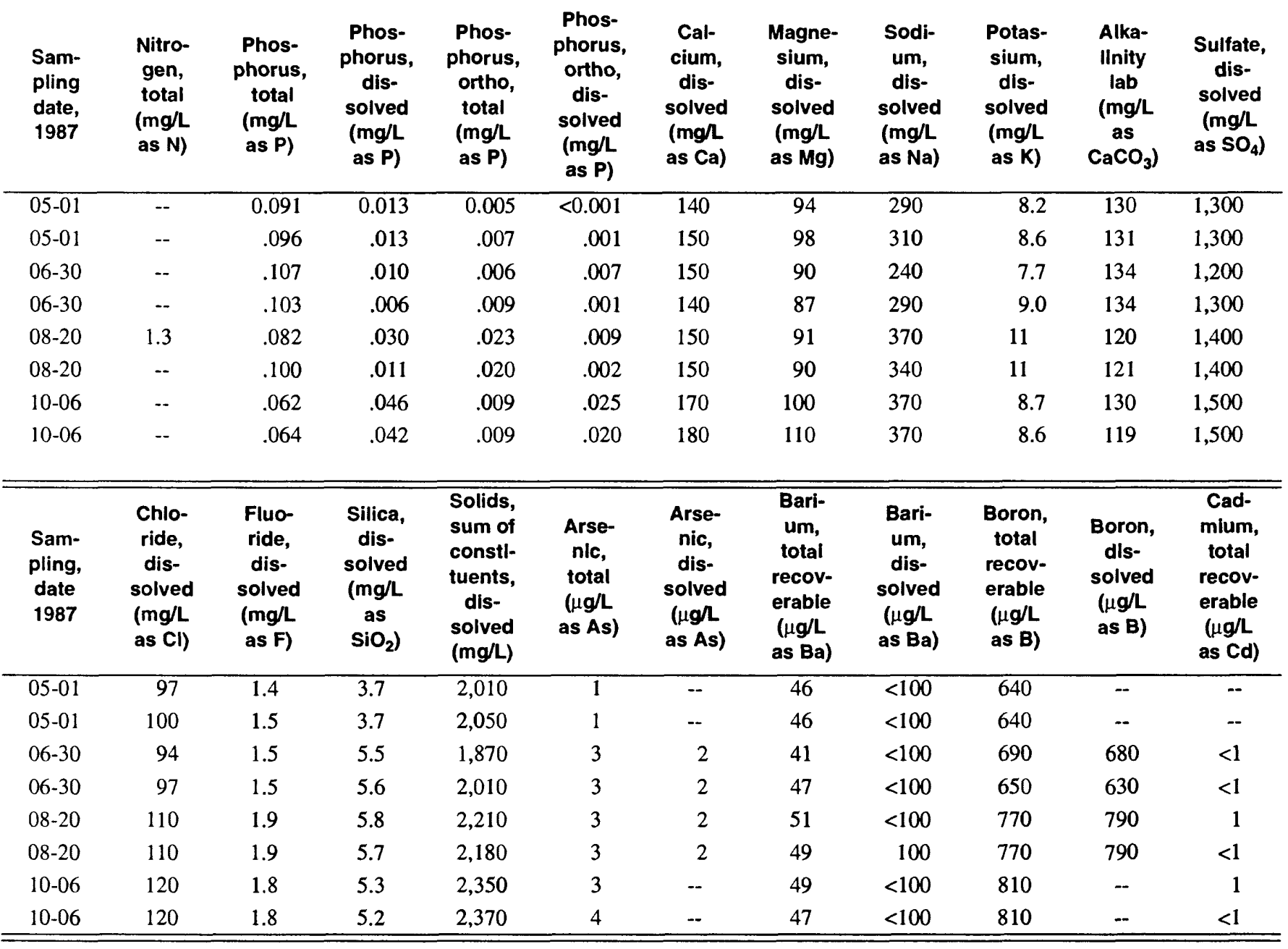


Table 19. Analyses of chemical constituents for site M2B at Lake Meredith--Continued

\begin{tabular}{|c|c|c|c|c|c|c|c|c|c|c|c|}
\hline $\begin{array}{c}\text { Sam- } \\
\text { pling } \\
\text { date } \\
1987\end{array}$ & $\begin{array}{l}\text { Cad- } \\
\text { mium } \\
\text { dis- } \\
\text { solved } \\
(\mu \mathrm{g} / \mathrm{L} \\
\text { as Cd) }\end{array}$ & $\begin{array}{l}\text { Chro- } \\
\text { mium, } \\
\text { total } \\
\text { recov- } \\
\text { erable } \\
(\mu g / L \text { as } \\
\text { Cr })\end{array}$ & $\begin{array}{l}\text { Chro- } \\
\text { mium, } \\
\text { dis- } \\
\text { solved } \\
(\mu \mathrm{g} / \mathrm{L} \\
\text { as Cr) }\end{array}$ & $\begin{array}{c}\text { Copper, } \\
\text { total } \\
\text { recov- } \\
\text { erable } \\
(\mu g / L \\
\text { as Cu) }\end{array}$ & $\begin{array}{c}\text { Copper, } \\
\text { dis- } \\
\text { solved } \\
(\mu g / L \\
\text { as } \mathrm{Cu})\end{array}$ & $\begin{array}{l}\text { Iron, } \\
\text { total } \\
\text { recov- } \\
\text { erable } \\
\text { ( } \mu \mathrm{g} / \mathrm{L} \\
\text { as Fe) }\end{array}$ & $\begin{array}{l}\text { Iron, } \\
\text { dis- } \\
\text { solved } \\
(\mu \mathrm{g} / \mathrm{L} \\
\text { as Fe) }\end{array}$ & $\begin{array}{c}\text { Lead, } \\
\text { total } \\
\text { recov- } \\
\text { erable } \\
(\mu \mathrm{g} / \mathrm{L} \\
\text { as } \mathrm{Pb})\end{array}$ & $\begin{array}{l}\text { Lead, } \\
\text { dis- } \\
\text { solved } \\
(\mu g / L \\
\text { as Pb) }\end{array}$ & $\begin{array}{l}\text { Manga- } \\
\text { nese, } \\
\text { total } \\
\text { recov- } \\
\text { erable } \\
\text { ( } \mu \mathrm{g} / \mathrm{L} \\
\text { as } \mathrm{Mn} \text { ) }\end{array}$ & $\begin{array}{c}\text { Manga- } \\
\text { nese, } \\
\text { dis- } \\
\text { solved } \\
(\mu \mathrm{g} / \mathrm{L} \\
\text { as } \mathrm{Mn})\end{array}$ \\
\hline $05-01$ & -- & 6 & - & 5 & - & 180 & - & 5 & - & 100 & -- \\
\hline $05-01$ & -- & 14 & -- & 5 & - & 320 & -- & $<5$ & -- & 140 & -- \\
\hline $06-30$ & 2 & $<10$ & $<10$ & 2 & 1 & 700 & 20 & $<5$ & $<5$ & 120 & 30 \\
\hline $06-30$ & $<1$ & $<10$ & $<10$ & 5 & 1 & 730 & 20 & 5 & $<5$ & 120 & 20 \\
\hline $08-20$ & $<1$ & 10 & $<10$ & 3 & 1 & 720 & $<10$ & $<5$ & $<5$ & 150 & 30 \\
\hline $08-20$ & 1 & $<10$ & $<10$ & 3 & 1 & 660 & 20 & $<5$ & $<5$ & 160 & 30 \\
\hline $10-06$ & -- & 11 & -- & 3 & -- & 840 & -- & $<5$ & -- & 250 & -- \\
\hline $10-06$ & -- & 4 & - & 6 & -- & 1,000 & -- & $<5$ & -- & 270 & - \\
\hline $\begin{array}{c}\text { Sam- } \\
\text { pling, } \\
\text { date } \\
1987\end{array}$ & $\begin{array}{c}\text { Mercury } \\
\text { total } \\
\text { recov- } \\
\text { erable } \\
(\mu \mathrm{g} / \mathrm{L} \\
\text { as } \mathrm{Hg})\end{array}$ & $\begin{array}{c}\text { Mercury } \\
\text { dis- } \\
\text { solved } \\
(\mu \mathrm{g} / \mathrm{L} \\
\text { as } \mathrm{Hg})\end{array}$ & $\begin{array}{c}\text { Nickel, } \\
\text { total } \\
\text { recov- } \\
\text { erable } \\
\text { ( } \mu \mathrm{g} / \mathrm{L} \\
\text { as } \mathrm{Ni})\end{array}$ & $\begin{array}{c}\text { Nickel, } \\
\text { dis- } \\
\text { solved } \\
\text { ( } \mu \mathrm{g} / \mathrm{L} \\
\text { as Ni) }\end{array}$ & & & $\begin{array}{c}\text { Sele- } \\
\text { nium, } \\
\text { dis- } \\
\text { solved } \\
(\mu \mathrm{g} / \mathrm{L} \\
\text { as Se) }\end{array}$ & $\begin{array}{c}\text { Silver, } \\
\text { total } \\
\text { recov- } \\
\text { erable } \\
(\mu \mathrm{g} / \mathrm{L} \\
\text { as Ag) }\end{array}$ & $\begin{array}{l}\text { Silver, } \\
\text { dis- } \\
\text { solved } \\
(\mu g / \mathrm{L} \\
\text { as Ag) }\end{array}$ & $\begin{array}{c}\text { Zinc, } \\
\text { total } \\
\text { recov- } \\
\text { erable } \\
(\mu \mathrm{g} / \mathrm{L} \\
\text { as } \mathrm{Zn})\end{array}$ & $\begin{array}{c}\text { Zinc, } \\
\text { dis- } \\
\text { solved } \\
(\mu \mathrm{g} / \mathrm{L} \\
\text { as } \mathrm{Zn})\end{array}$ \\
\hline $05-01$ & $<0.1$ & - & 2 & -- & & & -- & $<1$ & -- & 20 & - \\
\hline $05-01$ & $<.1$ & -- & 3 & -- & & & -- & $<1$ & -- & 10 & -- \\
\hline $06-30$ & $<.1$ & $<0.1$ & $<1$ & 2 & & & 4 & $<1$ & $<1.0$ & $<10$ & 20 \\
\hline $06-30$ & $<.1$ & $<.1$ & $<1$ & 2 & & & 4 & $<1$ & $<1.0$ & 10 & 20 \\
\hline $08-20$ & $<.1$ & -- & 8 & 7 & & & 4 & $<1$ & $<1.0$ & 30 & $<10$ \\
\hline $08-20$ & $<.1$ & $<.1$ & 4 & 4 & & & 4 & $<1$ & $<1.0$ & 20 & 10 \\
\hline $10-06$ & $<.1$ & -- & 11 & -- & & & -- & $<1$ & -. & $<10$ & - \\
\hline $10-06$ & $<.1$ & -- & 6 & -. & & & -- & $<1$ & -- & 10 & -- \\
\hline
\end{tabular}


Table 20. Analyses of chemical constituents for site M1B at Lake Meredith [mg/L, milligrams per liter; dashes indicate no data; <, less than; $\mu \mathrm{g} / \mathrm{L}$, micrograms per liter]

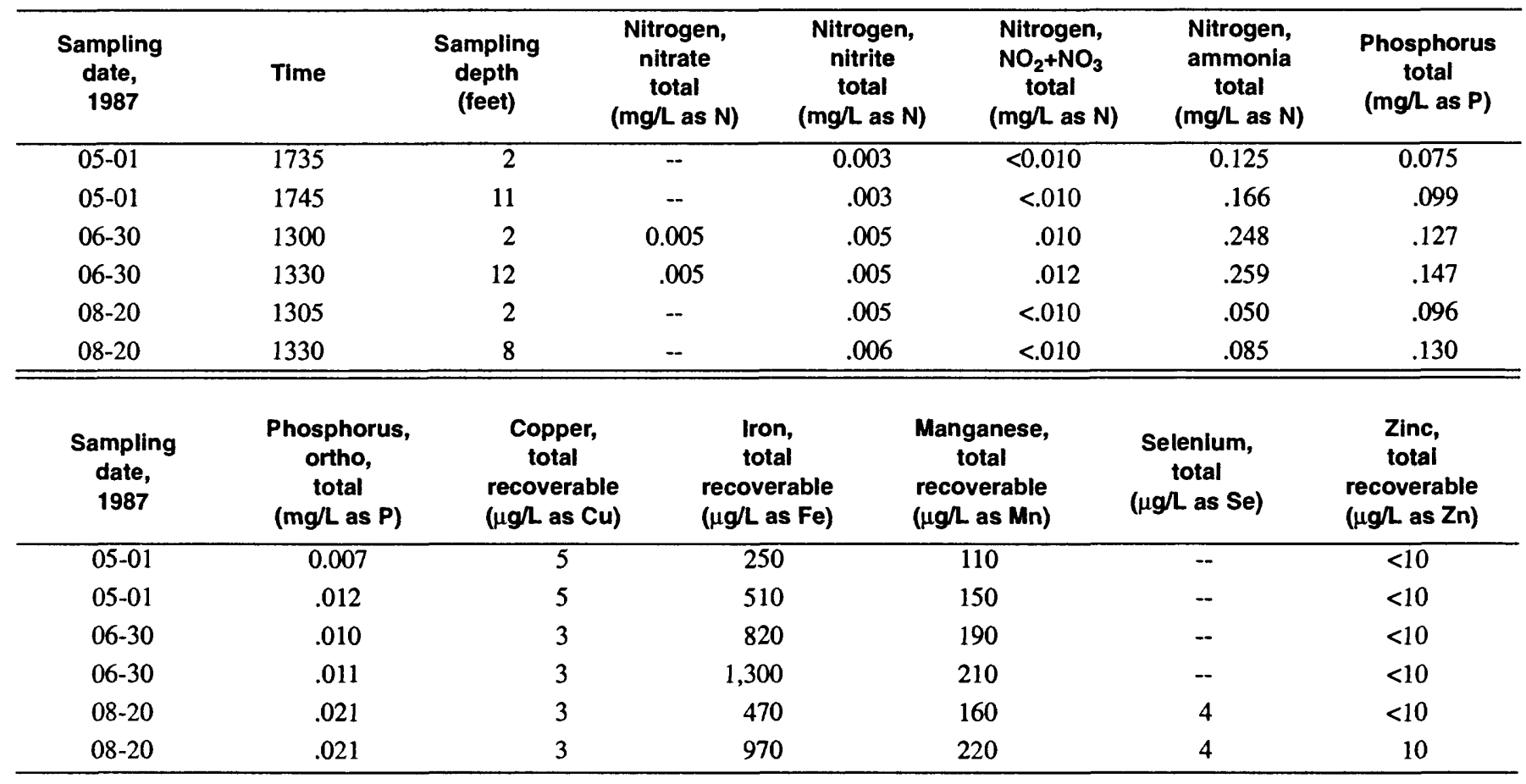

Table 21. Analyses of chemical constituents for site M4B at Lake Meredith

[mg/L, milligrams per liter; dashes indicate no data; <, less than; $\mu \mathrm{g} / \mathrm{L}$, micrograms per liter]

\begin{tabular}{|c|c|c|c|c|c|c|c|c|c|}
\hline \multirow{2}{*}{$\begin{array}{c}\text { Sampling } \\
\text { date, } \\
1987\end{array}$} & Time & $\begin{array}{l}\text { Sampling } \\
\text { depth } \\
\text { (feet) }\end{array}$ & \multicolumn{2}{|c|}{$\begin{array}{l}\text { Nitrogen, } \\
\text { nitrate } \\
\text { total } \\
\text { (mg/L as N) }\end{array}$} & \multicolumn{2}{|c|}{$\begin{array}{l}\text { Nitrogen, } \\
\text { nitrite } \\
\text { total } \\
\text { (mg/l as } N \text { ) }\end{array}$} & \multirow{2}{*}{$\begin{array}{c}\begin{array}{c}\text { Nitrogen, } \\
\mathrm{NO}_{2}+\mathrm{NO}_{3} \\
\text { total } \\
\text { (mg/L as } \mathrm{N} \text { ) }\end{array} \\
<0.010\end{array}$} & \multirow{2}{*}{$\begin{array}{c}\begin{array}{c}\text { Nitrogen, } \\
\text { ammonia } \\
\text { total } \\
\text { (mg/L as N) }\end{array} \\
0.168\end{array}$} & \multirow{2}{*}{$\begin{array}{c}\begin{array}{c}\text { Phosphorus, } \\
\text { total } \\
\text { (mg/ as P) }\end{array} \\
0.101\end{array}$} \\
\hline & 1840 & 2 & \multicolumn{2}{|c|}{--} & \multicolumn{2}{|c|}{0.004} & & & \\
\hline $05-01$ & 1845 & 8 & \multicolumn{2}{|c|}{-} & \multicolumn{2}{|c|}{.004} & $<.010$ & .166 & .108 \\
\hline $06-30$ & 1450 & 2 & \multicolumn{2}{|c|}{-} & \multicolumn{2}{|c|}{.004} & $<.010$ & .072 & .148 \\
\hline $06-30$ & 1505 & 8 & \multicolumn{2}{|c|}{-- } & \multicolumn{2}{|c|}{.005} & $<.010$ & .106 & .093 \\
\hline $08-21$ & 0945 & 2 & \multicolumn{2}{|c|}{-} & \multicolumn{2}{|c|}{.005} & $<.010$ & .034 & .147 \\
\hline $08-21$ & 1000 & 4 & \multicolumn{2}{|c|}{0.003} & \multicolumn{2}{|c|}{.022} & .025 & .053 & .144 \\
\hline $\begin{array}{c}\text { Sampling } \\
\text { date, } \\
1987\end{array}$ & $\begin{array}{c}\text { Phosphorus, } \\
\text { ortho, } \\
\text { total } \\
\text { (mg/L as P) }\end{array}$ & $\begin{array}{r}\text { Co } \\
t \\
\text { reco } \\
(\mu g / l\end{array}$ & & $\begin{array}{r}1 \\
\text { reco } \\
(\mu g /)\end{array}$ & $\begin{array}{l}\text { i, } \\
\text { rable } \\
\text { s Fe) }\end{array}$ & & $\begin{array}{l}\text { anese, } \\
\text { tal } \\
\text { erable } \\
\text { as Mn) }\end{array}$ & $\begin{array}{c}\text { Selenium, } \\
\text { total } \\
\text { ( } \mu \mathrm{g} / \mathrm{L} \text { as } \mathrm{Se})\end{array}$ & $\begin{array}{c}\text { Zinc, } \\
\text { total } \\
\text { recoverable } \\
\text { ( } \mu g / L \text { as } Z n)\end{array}$ \\
\hline $05-01$ & 0.012 & & & & & & 10 & -- & $<10$ \\
\hline $05-01$ & .013 & & & & & & 20 & -- & $<10$ \\
\hline $06-30$ & .010 & & & & & & 60 & -- & 10 \\
\hline $06-30$ & .011 & & & & & & 30 & -- & $<10$ \\
\hline $08-21$ & .048 & & & & & & 90 & 4 & 20 \\
\hline $08-21$ & .051 & & & & & & 00 & 4 & 20 \\
\hline
\end{tabular}


Table 22. Phytoplankton densities for site M2B at Lake Meredith

[cells/mL, cells per milliliter; dashes indicate taxa not detected; sp., species are distinguishable but not identifiable; var., identifies a variation in the species; ?, species identification probable but not positive; densities are rounded to standard significant figures (Britton and Greeson, 1989)]

\begin{tabular}{|c|c|c|c|c|}
\hline \multirow{2}{*}{ Taxa } & \multicolumn{4}{|c|}{ Densities (celis/mL) for indicated sampling date } \\
\hline & $05-01-87$ & $06-30-87$ & $08-20-87$ & 10-06-87 \\
\hline \multicolumn{5}{|l|}{ BACILLARIOPHYTA (Diatoms) } \\
\hline \multicolumn{5}{|l|}{ Order Centrales } \\
\hline Chaetoceros sp. & -- & 110 & 19,000 & -- \\
\hline Cyclotella bodanica & 57 & -- & -- & -- \\
\hline Cyclotella kutzingiana & -- & -- & 2,800 & -. \\
\hline Cyclotella meneghiniana & 57 & -- & 2,300 & 9,600 \\
\hline Cyclotella stelligera & 4,100 & 110 & 1,100 & -. \\
\hline Melosira sp. & -- & -- & -- & 570 \\
\hline Stephanodiscus niagarae & 110 & -- & -- & -- \\
\hline Stephanodiscus sp. & -- & -- & 2,300 & -- \\
\hline \multicolumn{5}{|l|}{ Order Pennales } \\
\hline Entomoneis alata & -- & -- & -- & 14 \\
\hline Entomoeneis paludosa & 7 & -- & -- & - \\
\hline Navicula pelliculosa & -- & -- & 1,100 & - \\
\hline Navicula secreta var. apiculata & 7 & -- & -- & -- \\
\hline Nitzschia acicularis & -- & -- & -- & 570 \\
\hline Nitzschia intermedia & -- & -- & 230 & - \\
\hline Nitzschia longissima var. reversa & -- & -- & 570 & -- \\
\hline Nitzschia palea & 14 & -- & 570 & -- \\
\hline Nitzschia sp. & -- & - & -- & 1,700 \\
\hline Synedra rumpens & -- & -- & -- & 27 \\
\hline \multicolumn{5}{|l|}{ CHLOROPHYTA (Green algae) } \\
\hline Actinastrum hantzschii & -- & -- & 1,700 & -- \\
\hline Ankistrodesmus convolutus & 800 & 570 & -- & -- \\
\hline Ankistrodesmus falcatus var. mirabilis & -- & 110 & -- & 570 \\
\hline Ankistrodesmus nannoselene & -- & -- & -- & 1,700 \\
\hline Ankistrodesmus sp. & -- & -- & -- & 2,800 \\
\hline Chlamydomonas sp. & 400 & -- & 1,700 & -- \\
\hline Chlamydomonas sp. 1 & -- & -- & -- & 1,100 \\
\hline Chlamydomonas sp. 2 & -- & -- & - & 5,700 \\
\hline Chlamydomonas sp. 3 & -- & -- & -- & 3,400 \\
\hline Chlorella sp. & 450 & -- & 1,700 & 570 \\
\hline Chlorococcum humicola & -- & -- & 2,800 & -- \\
\hline Chlorococcum sp. & 400 & -- & -- & -- \\
\hline Chlorogonium sp. & -- & - & -- & 570 \\
\hline Chodatella quadriseta & 57 & -- & 1,100 & -- \\
\hline Chodatella wratislawiensis & -- & -- & 2,800 & - \\
\hline Closterium sp. & 57 & -- & -- & 27 \\
\hline
\end{tabular}


Table 22. Phytoplankton densities for site M2B at Lake Meredith--Continued

\begin{tabular}{|c|c|c|c|c|}
\hline \multirow{2}{*}{ Taxa } & \multicolumn{4}{|c|}{ Densities (cells/mL) for indicated sampling date } \\
\hline & 05-01-87 & $06-30-87$ & $08-20-87$ & 10-06-87 \\
\hline \multicolumn{5}{|l|}{ CHLOROPHYTA (Green algae)--Continued } \\
\hline Coccomyxa sp. & - & -- & -- & 1,100 \\
\hline Coelastrum sp. & -- & -- & 3,400 & - \\
\hline Crucigenia apiculata & - & -- & 9,100 & - \\
\hline Crucigenia tetrapedia & - & 450 & -- & -- \\
\hline Dictyosphaerium ehrenbergianum & 1,900 & -- & 6,800 & - \\
\hline Dictyosphaerium pulchellum & 1,500 & -- & 4,500 & 8,000 \\
\hline Franceia ovalis & -- & -- & 230 & -- \\
\hline Gloeocystis sp. & 680 & -- & 1,700 & - \\
\hline Kirchneriella contorta & 450 & 570 & -- & -- \\
\hline Kirchneriella lunaris & 110 & 450 & 6,200 & 3,400 \\
\hline Kirchneriella obesa & -- & -- & -- & 6,800 \\
\hline Mesotaenium sp. & 57 & -- & - & -- \\
\hline Nephrocytium agardhianum & -- & -- & 1,100 & 3,400 \\
\hline Oocystis borgei & -- & -- & 2,800 & -- \\
\hline Oocystis gloeocystiformis & 340 & 230 & - & - \\
\hline Oocystis lacustris & -- & 450 & 570 & - \\
\hline Oocystis pusilla & 4,600 & -- & 110 & -- \\
\hline Oocystis sp. & 1,100 & 230 & - & 1,100 \\
\hline Scenedesmus accuminatum & -- & -- & 2,300 & 2,300 \\
\hline Scenedesmus armatus & -- & 230 & 1,100 & 1,100 \\
\hline Scenedesmus bijuga & - & -- & -- & 2,300 \\
\hline Scenedesmus dimorphus & -- & - & -- & 2,300 \\
\hline Scenedesmus quadricauda & 110 & -- & -- & - \\
\hline Scenedesmus serratus & -- & 450 & 1,100 & 1,100 \\
\hline Scenedesmus sp. & 230 & -- & 1,100 & -- \\
\hline Schroederia judayi & -- & 110 & -- & - \\
\hline Schroederia setigera & -- & 230 & 570 & - \\
\hline Selenastrum minuta & 57 & -- & -- & - \\
\hline Selenastrum minutum & -- & - & 1,700 & -- \\
\hline Sphaerocystis schroeteri & 910 & - & -- & -- \\
\hline Tetraedron minimum & -- & -- & 3,400 & - \\
\hline Tetrastrum staurogeniaeforme & -- & 450 & -- & 1,700 \\
\hline \multicolumn{5}{|l|}{ CHRYSOPHYTA (Golden-brown algae) } \\
\hline Ochromonas sp. & 57 & -- & -- & - \\
\hline \multicolumn{5}{|l|}{ CRYPTOPHYTA (Cryptomonads) } \\
\hline Chroomonas sp. & 57 & - & -- & 6,200 \\
\hline Cryptomonas erosa & -- & - & - & 570 \\
\hline Rhodomonas minuta & 970 & - & -- & 570 \\
\hline
\end{tabular}


Table 22. Phytoplankton densities for site M2B at Lake Meredith--Continued

\begin{tabular}{|c|c|c|c|c|}
\hline \multirow{2}{*}{ Taxa } & \multicolumn{4}{|c|}{ Densities (celis/mL) for indicated sampling date } \\
\hline & $05-01-87$ & $06-30-87$ & $08-20-87$ & $10-06-87$ \\
\hline \multicolumn{5}{|l|}{ CYANOPHYTA (Blue-green algae) } \\
\hline Anabaenopsis circularis & -- & -- & -- & 16,000 \\
\hline Aphanizomenon flos-aquae & - & -- & 12,000 & -- \\
\hline Aphanocapsa delicatissima & 11,000 & -- & 17,000 & 23,000 \\
\hline Aphanocapsa elachista & -- & -- & 9,100 & -- \\
\hline Aphanothece nidulans & -- & -- & 130,000 & $2,600,000$ \\
\hline Aphanothece sp. & 17,000 & -- & 440,000 & -- \\
\hline Chroococcus dispersus & 340 & 16,000 & 18,000 & -- \\
\hline Chroococcus limneticus & 400 & -- & -- & -- \\
\hline Dactylococcopsis acicularis & -- & -- & 570 & -- \\
\hline Dactylococcopsis fascicularis & -- & 2,600 & 570 & 1,100 \\
\hline Dactylococcopsis smithii & -- & 800 & -- & -- \\
\hline Lyngbya limnetica & -- & 4,800 & 860,000 & 740,000 \\
\hline Marssoniella elegans & -- & -- & 57,000 & - \\
\hline Merismopedia minimum & -- & -- & -- & 14,000 \\
\hline Merismopedia tenuissima & -- & 260,000 & 27,000 & - \\
\hline Microcystis incerta & -- & $1,800,000$ & 630,000 & 310,000 \\
\hline Microcystis sp. & 3,600 & -- & -- & -- \\
\hline Oscillatoria angustissima & - & -- & 70,000 & 89,000 \\
\hline Oscillatoria limnetica & 1,400 & -- & 23,000 & 12,000 \\
\hline Oscillatoria subtilissima & 3,700 & -- & -- & -- \\
\hline Oscillatoria tenuis & -- & -- & 18,000 & -- \\
\hline Romeria sp. & -- & 3,600 & 4,500 & 34,000 \\
\hline Spirulina sp. & -- & -- & -- & 10,000 \\
\hline Synechococcus sp. & -- & -- & 4,500 & -- \\
\hline \multicolumn{5}{|l|}{ EUGLENOPHYTA (Euglenoids) } \\
\hline Euglena acus & -- & -- & 280 & 280 \\
\hline Euglena oxyuris var. minor & -- & 110 & -- & -- \\
\hline Euglena sp. & 400 & -- & -- & 570 \\
\hline Euglena viridis & -- & -- & -- & 570 \\
\hline Phacus sp. & -- & - & -- & 570 \\
\hline Trachelomonas planctonica & -- & - & -- & 280 \\
\hline \multicolumn{5}{|l|}{ PYRRHOPHYTA (Dinoflagellates) } \\
\hline Peridinium libatum? & 28 & -- & -- & -- \\
\hline Total, cells $/ \mathrm{ml}$ & 58,000 & $2,100,000$ & $2,400,000$ & $3,900,000$ \\
\hline Number of species & 38 & 23 & 51 & 46 \\
\hline
\end{tabular}

